\title{
"A Kind of Character in thy Life": Shakespeare and the Character of History
}

\author{
Peter Holland \\ University of Notre Dame
}

\begin{abstract}
This article explores the early modern concept of "character" and Shakespeare's use of the word - as a way to rethink the nature of Shakespearean biography. Through the material of evidence of Shakespeare's character, his writing, I turn to the figuring of "history" in Shakespeare's plays, the writing of letters (leaving traces of characters as writing), before finally imaging a different kind of Shakespeare biography.

KEYWORDS: biography, character, history, Richard Quiney, Henry IV Part 2.
\end{abstract}

The circle of my concerns in this article began as a complex interaction or intertwining between Shakespeare's biography and Shakespeare's writing of biographies, between, in effect, two forms of history. It was in part an avenue for me to think through a way both of writing Shakespeare's biography and of writing about it again, this time for Bruce Smith's forthcoming Cambridge World Shakespeare Encyclopedia. The interlacing is driven by my increasing anxiety about what kind of history we can make of Shakespeare's life, how or whether to connect the points of knowledge into a narrative. But enough by way of preface.

As the Duke in Measure for Measure prepares to unfold to Escalus his plan to leave Angelo in charge in Vienna, he asks,

\footnotetext{
* This article began life as a lecture for the Huntington Library in Pasadena, California, and then as the 2010 Sam Wanamaker Lecture at Shakespeare's Globe in London. My thanks to both organizations for the invitation.
} 
perhaps seeking reassurance, "What figure of us think you he will bear?" Moments later, after Angelo enters, "Always obedient to your Grace's will," the Duke begins the transfer of power with a comment whose specific meaning for our understanding of Angelo the play will only later start to unpack: "Angelo, | There is a kind of character in thy life|That to th'observer doth thy history|Fully unfold" (1.1.16, 25-29). ${ }^{1}$ My concern is initially going to be with the collocation of three of the Duke's nouns - figure, character and history - and with the semantic fields within which they operate in early modern usage and in Shakespeare's writing, intertwining with each other as they make themselves apparent to those observers, the spectators who watch characters unfolding themselves through their histories, trying to figure out the figures before them.

Though character did not yet mean a role played by an actor in a play - that seems to be only a post-Restoration usage - Joseph Hall's Characters of Vertues and Vices (1608) and the first group of Overbury's "many witty Characters" in 1614 mark a new stage of interest in the presence of the Theophrastan form in England, those brief prose descriptions of a type of socially observed individual ${ }^{2}-$ and it is their status as brief and fragmentary and fixed that I will want to use later. But Shakespeare had long been keen on the word and its cognates. As characters start to be "charactered," filled from their initial status as "characterless" - a word for which the OED gives Shakespeare's Troilus and Cressida as its first example ("And mighty states characterless are grated |To dusty nothing," 3.2.184185) - to becoming not "characterful," a word not yet in use, but perhaps "characterical," "characteristical," "characterized," for, though they could not yet show their "characteristics," they might start to acquire "characterisms," of the kind that Ben Jonson attached to the "persons of the play" listed in the printed text of The New Inn, each of whom now had "some short characterism of the chief actors" to describe them (see Berger 1997). ${ }^{3}$ Such a grouping of characters might in theory be called a "charactery," a word Shakespeare used both for collections of symbols (characters in the sense of letters of

\footnotetext{
${ }^{1}$ Quotations from Shakespeare are from Wells' edition (1986).

${ }^{2}$ The first Overbury group is printed in the second edition of Sir Thomas Overbury, $A$ Wife Now the Widow (1614) and expanded in a number of subsequent editions in 1614 and 1616. For details of the progression of inclusion, see W.J.Paylor (1936).
}

${ }^{3}$ Quoted in OED, characterism 1. 
the alphabet or similar symbolic systems), for, in Merry Wives, "Fairies use flowers for their charactery" (5.5.72), and for the marks and traces which for Brutus are inscribed as "All the charactery of my sad brows" (Julius Caesar, 2.1.307), those signs of a troubled mind that Portia wants to understand, to be able to read or decode but which depend on the character's expounding, laying bare his own character to her as he has already done to the spectators who can read what his wife cannot.

But the devices of character, the ways in which a character is formed in a play are also, in a sense, part of that exceptional skill in moral philosophy that Joseph Hall identified at the start of his Characters of Vertues and Vices as the art of certain "Divines of the olde Heathens" who "bestowed their time in drawing out the true lineaments of every vertue and vice, so lively, that who saw the medals, might know the face: which Art they significantly termed Charactery" (Hall 1608:A5a). The compact way in which such character-study might be delineated either in one of Hall's characters or in Shakespeare's creation of characters might also be "charactery" in another sense, as that "arte of shorte, swifte and secrete writing by character," the shorthand system that Timothy Bright invented and published in his book Characterie in 1588. The epistemology that makes character visible is a product of precisely the brevity and rapidity of shorthand and the decoding that the secret writing system requires. An early modern playgoer may be learned in the charactery of performance, in the notational forms through which an actor denotes his characters, moving from the other notational forms of writing by the playwright to the representation of a person charactered in action.

We are of course used to the connections between character and engraving, not least since Jonathan Goldberg explored some of this nexus in his look at "the inscription of character" in an article that rightly found its place in his collection Shakespeare's Hand (Goldberg 2003:10-47, esp.31-38; see also Lieblein 2009). The sense of something distinctively stamped or impressed is there in Hall's reference to "medals." In the very last piece added to the ninth edition of Overbury's characters in 1616, there is a definition of "What a


signifieth to ingrave, or make a deepe Impression" (Paylor 1936:92). That root is most apparent in and present in the semantic field 
defined by the simplest form of the word in English, "charact." But the writer of the Overbury character also sees character as "an Egiptian Hierogliphicke, for an impresse, or shorte Embleme; in little comprehending much," pointing us to a recurrent undertone in the word, one that seems to be ignored by modern explorations of its meanings, for "charact" and "character" and their associated forms "characteric," "characterical" and "characeristical" are all used in relation to magical and cabbalistic symbolism, to the domain of secret meanings that have unknown power, to the potency of charms, talismans and spells. A character is in that sense a magical object, something that depends on learned skills and with symbolic meanings. Only then does the answer to "what a character is" move on to the specifically English version, "a picture (reall or personall) quaintlie drawne in various collours, all of them heightned by one shadowing" (Paylor 1936:92). Character as secret writing or as individual identity is a magical, charmed, powerful form, something hidden and needing particular skills to lay bare.

Most early modern dictionaries define "character" in senses that have nothing to do with individuation, emphasizing the imprint that creates a letter. So, for example, Thomas Thomas in his 1587 LatinEnglish dictionary, defines the Latin "character" as "A token, or note, a marke, signe, seal, or print in a thing: a letter, a figure, a stile, forme, manner of speaking or writing" (see Thomas at LEME). Against this norm, the ways in which Shakespeare uses the word are distinctly unusual. So, for instance, OED cites Twelfth Night as its first example for "The face or features as betokening moral qualities; personal appearance" (n.10) when Viola tells the Captain "I will believe thou hast a mind that suits $\mid$ With this thy fair and outward character" (1.2.46-47) - and we should note how the passage marks out a separation and hopefully an interconnection between inside and out, between the stamps and imprints that are "outward" and the unknowable "mind" within. Something similar is going on when Menenius, describing the terrifying image of Coriolanus moving "like an engine," tells Sicinius "I paint him in the character" (5.4.19, 27 ), both as a character portrait of the Overbury kind but also accurately, truthfully, in a lifelike representation of those visible qualities.

The grouping of individual characters, that is, the "graphical symbols" (OED 3.a) we know as letters of the alphabet, produces 
that distinctive mark of individuality in handwriting, that character that is the Duke's in Measure ("here is the hand and seal of the Duke. You know the character, I doubt not, and the signet is not strange to you," a character that the Provost recognizes, 4.2.192-194) and the one that is not Olivia's in Twelfth Night, "Though I confess much like the character" (5.1.343). The letter is in Maria's hand, which is so like Olivia's that "on a forgotten matter we can hardly make distinction of our hands" (2.3.154-155), but its effectiveness depends on Maria's assessment of the character of Malvolio. It suggests a transitioning of the term from writing to the personality of the individual but that depends not on Shakespeare's use of the word but rather on mine. But there are only two characters in Twelfth Night: the writing that is like Olivia's and the fair and outward character of the Captain.

But even more important for my concerns is the way that for Shakespeare an object can simultaneously be defined as belonging to two people through the shift in definitions of the word "character" in relation to it. The object is now his, now hers, because of the semantic change. Drama often depends on recognition tokens but when Antigonus leaves Perdita in Bohemia there is a clutch of objects left with her that are observed differently by different people. There are also, usually unnoticed, the ones that are taken (scavenged? stolen?) from Antigonus' corpse before burial by the clown, for the proof of Antigonus' identity as the corpse depends in part, says the Third Gentleman, on "a handkerchief and rings of his, that Paulina knows" (5.2.65-66). But with Perdita there is, as far as the shepherds old and young are concerned, a christening robe - the "bearing-cloth for a squire's child" (3.3.112) - together with objects that are "Gold, all gold!" (118). But there are also objects that the shepherds do not mention: there is the "mantle of Queen Hermione's, her jewel about the neck of it" that we hear of from the Third Gentleman (5.2.32-33). Though the mantle might, I suppose, be the "bearing-cloth," the shepherds do not comment on the jewel, only the gold that surrounds it, the "these" that Antigonus suggests "may, if fortune please, both breed thee, pretty, |And still rest thine" (3.3.46-48). And then there are, says the Gentleman narrating the recognition, the "letters of Antigonus found with it, which they know to be his character" (34-35). But the letters begin their dramatic life not as "his character" but as Perdita's: "There lie, and there thy character" (46) - and, again, these are significantly the only occurrences of "character" in the play. They are the written account 
of her identity, not a Theophrastan character of a social type, but they are also a character of a narrative and dramatic type, the abandoned baby, that which is lost which, of necessity, in drama will always be eventually found. Such writing, unread to us, has a character peculiar to its dramatic status, a character both of Antigonus in more ways than his handwriting and of Perdita in more ways than simply as a document of identification. But the metamorphosis of the possessive pronoun, "thy character" to "his character," is central to the transitions of meaning and of dramatic function that the single object creates, those letters as documents that are made up of letters as characters, as charactery, documents about her written by him, as the character changes from being sign of authorship (Antigonus') to sign of subject (Perdita's), from being written by to being written about.

We do not need to read these letters, these alphabetical characters that make up this letter in The Winter's Tale, or rather have it/them read to us. Their contents are self-evident in their meaning. But whenever we look at Shakespeare's will, that much-pored-over document, we look for different signs of character. They are there, of course, in the sense of his handwriting, at the foot of each page, the signature almost lost from the first sheet, more emphatically present on the second, and, on the third, with the assertion of authorship, of the act of authorizing, in the added phrase "By me," followed by the increasingly shaky handwriting that formed the characters of the surname. Shakespeare writes characters and we read back into the form of the characters, the impress that they make on the sheets of paper, meanings of, for instance, the state of his health. So Schoenbaum reads "By me" as "emphatic" as it validates the will but also that "the wavering scrawl of the surname" is a sign that in March 1616, on or after the visit of the lawyer Frances Collins on the $25^{\text {th }}$, "a feeble hand held the pen" (Schoenbaum 1975:246). But writing alphabetical characters as a signature is not the same as writing that reveals character. Collins did not produce a fair copy of the will for Shakespeare's signature and, just as much as the work of Hand D in his contributions to Sir Thomas More, the will shows all the signs of revision and rethinking, some perhaps made in January 1616 when he probably first visited Shakespeare, others certainly the result of changes between January and March, like the wedding of Shakespeare's daughter Judith to Thomas Quiney, Quiney's excommunication for failing to secure the right licence, and much 
more seriously the death of Margaret Wheeler in childbirth and the burial of her and her child on 15 March. The day after Shakespeare's will was dated, Quiney appeared in court to be tried for "carnal copulation" [carnalem copulacionem] with Wheeler, confessed his crime, received a sentence of open penance for three successive Sundays and bought himself out of such public humiliation for the small fee of five shillings for the poor of the parish (Schoenbaum 1975:239-240).

The first sheet of the will was completely rewritten, though even the new version has deletions and interlineations, the whole probably in the hand of Frances Collins' clerk. The second and third sheets are full of changes, changes that we want to read as signs of character, changes we want to characterize, to read back into intention, to use as signs of interiority and intentionality just as much as we do when looking at Shakespeare's characters in the plays. Take, for instance, this provision: "\& to my ffellowes John Hemynge Richard Burbage \& Henry Cundell $x x v j^{\mathrm{s}}$ viij $\mathrm{d}$ A peece to buy them Ringes." 4 How do we read the meaning of its interlineated status, its sign of addition? Was it always intended but written in at this point for some formal reason to align it with other such bequests for rings to people in Stratford like Hamlett Sadler, William Raynoldes, William Walker, Anthonye Nashe and John Nashe? Was it an afterthought? Why only these three of the King's Men? That Heminges and Condell went on to edit the Folio has prompted the thought that the two events, the bequest and the editing, are somehow interconnected, that Shakespeare might have already been thinking about the planning of a collection of his plays and that the rings are therefore able to be construed as a sign of entrusting the two friends with the task.

But the object, the will's bequests to Heminges and Condell, resolutely resists such interpretation. We can read it as biographical document pointing towards a future printing only if we are prepared to read as readers of Shakespeare's plays, to read it as manifesting a history that not only reaches back through the years of Shakespeare's involvement with one company, with three at least of whom he might not unreasonably be friendly enough to make a

\footnotetext{
${ }^{4}$ I use the transcription in Chambers (1930:2.172).
} 
bequest, but also must be seen as reaching forward, as a sign or portent, a figure that prefigures an event seven years later.

And if such reading of this comparatively simple provision is, in effect, a denial of adequate historiography in favour of a creation of purpose that we might wish to find, a statement of connection to a printed object whose production we might hope to show as authorized in as many senses as possible, then the anxiety about the meaning of the second-best bed is even more complete as a desire to create a history, to find not only in the nature of the bequest but also in its status as interlineation (therefore supposedly to be seen as afterthought) and in its absences of terms of endearment a statement about the marriage. We want, that is, to read from the character of these characters, these acts of inscription, to a history as personal narrative, no grand récit, but a narrative whose significance depends on the historical power of the individual about whom the narrative is being constructed. We yearn to narrativize.

And that leads me back to Angelo's history that will be unfolded in the course of Measure for Measure. Shakespeare's histories, I want to emphasize, are far more substantively narratives of individuals, what the $O E D$ calls "The whole train of events connected with a particular [...] person, [...] and forming the subject of his [...] history" (n.4.b), than we have tended to assume. History for Shakespeare can occasionally be generic, as in Polonius' catalogue or in the Page's definition to Christopher Sly of the drama they will watch, "It is a kind of history" (The Taming of the Shrew, Induction, 2.140) - and it might be worth recalling that in Henry Cockeram's dictionary of 1623 tragedy is defined as "a History or play of death" and comedy as "a History or play of mirth" (Cockeram at $L E M E$ ). But most dominantly for Shakespeare, it is the narrative of a person's life, for, as Jaques argues in As You Like It, following conventional tropes, all human life can be seen as a form of drama in seven scenes that adds up to being a "strange, eventful history" (As You Like It, 2.7.164). Individual lives are histories. So Orsino asks Cesario about her/his father's daughter, "And what's her history?" (2.4.109); Marina tells Pericles "If I should tell|My history, it would seem like lies|Disdain'd in the reporting" (21.106108); Brutus tells his "countrymen" that "Brutus' tongue|Hath almost ended his life's history" (Julius Caesar, 5.5.33, 39-40); and Warwick, in a crucial speech to Henry IV, begins by defining his 
terms: "There is a history in all men's lives|Figuring the nature of the times deceased" (Henry IV Part 2, 3.1.75-76). It is a passage I shall come back to soon. Whoever in the printing/publishing industry gave Shakespeare's plays different titles at different times was working at the same intersection of individual and history: Henry VIII has running-heads in the Folio that identify it as "The Famous History of the Life of King HENRY the Eight," Q1 and Q2 call Hamlet "The Tragicall Historie of Hamlet, Prince of Denmarke," King Lear started its print-life as "His True Chronicle Historie of the life and death of King Lear and his three Daughters" in 1608, some of the plays the Folio groups as "Histories" are also called "The Life and Death" of the central character (Richard III, King John, Richard II), Henry V is "The Life" in Folio and "The Chronicle History" in quarto, the first issue of the first quarto of Troilus and Cressida is "The History," and so on. And, when Nicholas Rowe first wrote Shakespeare's biography, he praised his histories where a reader/playgoer "will find the Character as exact in the Poet as the Historian" and continues,

He seems indeed so far from proposing to himself any one Action for a Subject, that the Title very often tells you, 'tis The Life of King John, King Richard, \&c. What can be more agreeable to the Idea our Historians give of Henry the Sixth, than the Picture Shakespear has drawn on him! His Manners are everywhere exactly the same with the Story [...]. (Rowe 1709:1.xviii)

And I am unembarrassed to find myself in Rowe's company.

But it is Warwick's use of "figuring" that I first want to worry at a little, especially recalling that collocation of history and figure at the opening of Measure. Where character could not yet mean a representation in a play, figure could. Think of Ariel who, Prospero tells him after the banquet that is not eaten, "Bravely the figure of this harpy hast thou|Performed" (3.3.83-84). This is OED's earliest citation in this sense (n.11.a). As "character" entangles the individual and the symbolic representations of language, so too does "figure." No wonder that the soldier in Timon who finds the epitaph, combines the two words: "The character I'll take with wax.|Our captain hath in every figure skill,|An aged interpreter, though young in days" (5.4.5-7). There is the rhetorical figure that is so dominant as a meaning in early modern dictionaries (OED 21) and the symbols (letter as well as number) that create the words, that system of language in which the captain is skilled (OED 18-19). There are the diagrammatic and ornamental figures (OED 13-15). 
But, where OED as it sorts out the meanings of "character" moves from the imprint towards the individual, the sequence for "figure" is the reverse, moving from the outward shape of something or someone through the represented form or likeness to the written character. Character, one might say, becomes an individual, figure develops from being an individual's appearance.

Warwick is not speaking of the external shape of the body, the figure that represents or the ornamental. Rather, he is engaging with the ways in which history reveals a patterning, unfolds its figures, representing its diagrammatical basis, not least as an act of the mind or imagination. We could compare the way in which a gentleman in Measure tells Lucio "Thou art always figuring diseases in me, but thou art full of error - I am sound" (1.2.51-52). Since figuring can be representing, it can show or purport to show that which, as Hamlet defines it, precisely because it is internal, is "that within" which must necessarily or can conceivably be something that "passeth show" (1.2.85). So, as Anne is accompanying the corpse of Henry VI, that "key-cold figure of a holy king" (Richard III, 1.2.5), she meets Richard whose heart, or so he claims, is "figured in my tongue" (1.2.181). This act of figuring moves from inside outside; it is in a more serious way an act of figuring out. But Warwick's suggestion is that the understanding of individual histories is the accurate decoding and simplifying of the complexity of a series of events into a pattern, a shape, a form, that which has been, those events that are the mark of history both as individual events and as the fact of their pastness, their being an aspect of "the times deceased." The diagram is the process by which the individual in history and the individual's history is figured.

But, as the three states of time - history, immediacy and possibility, or past, present and future - demand an awareness of their sequentiality, that that which is past, is history, is always already signifying the possibilities of the future, so the verb form of "figure" also suggests "prefigure" (OED v.5), as in Henry VI Part 3: when the three suns appear in the air to York's sons after the battle of Wakefield, it is Richard who asserts "In this the heaven figures some event" (2.1.32). Here the diagram that the suns make, the diagrammatic figure that they represent, portends something to come, not something past, figuring the nature of the times but in a 
different time-field, no longer times deceased but times as yet unborn.

So Warwick in 2 Henry IV sees a profound interconnection of possibilities between the understanding of the past and the prediction of the future.

There is a history in all men's lives

Figuring the nature of the times deceased;

The which observed, a man may prophesy,

With a near aim, of the main chance of things

As yet not come to life, who in their seeds

And weak beginnings lie intreasurèd. (Henry IV Part 2, 75-80)

Analysing the past, that history which can be observed, enables one to gauge the likelihood of future events. The seeds and weak beginnings of the future lie in the past. But the prediction is not guaranteed to be accurate; it is only "With a near aim," a reasonable shot but one that may miss the target and, in any case, is trying to point towards the "main chance," a complex form of the central issues of fortune ("issues" in Shakespeare's usual sense of consequences, not our meaning as "problems, those things which are at issue"). The side outcomes may not even be guessed at with such a reasonable chance.

Warwick's movement from history to futurity is one that Henry IV manages completely to misunderstand: "Are these things then necessities?|Then let us meet them like necessities" (87-88). But Warwick has carefully and sensibly argued that these things are not necessities, only probabilities. When Richard considered what Northumberland had done to him, he might predict what Northumberland might do to his successor: "King Richard might create a perfect guess|That great Northumberland, then false to him, | Would of that seed grow to a greater falseness, | Which should not find a ground to root upon|Unless on you" (84-86). But the "guess" only turns out to be accurate, "perfect," in retrospect, as it becomes history, as it, more narrowly, proves to be part of Northumberland's history, the history of this man's life. There is nothing in Northumberland's earlier actions that necessitates the later ones, only that there are seeds that might root and sprout in a parallel or comparable way, provided that there proves to be fertile soil for rebellion, "ground" which Henry conveniently supplied. The sequence of repetition is not inevitable, only a possibility that grows 
to probability the more one observes past times, dead times, times deceased.

Henry had, indeed, understood this process when he first opened the topic, defining Richard II's comment as "words, now proved a prophecy" (64). As Henry goes on to quote more of Richard's language, not quite accurately repeating what he heard and we may have heard in the earlier play, ${ }^{5}$ altering its historical record, the data of the event, his phrasing oscillates between event and inevitability:
"The time shall come" - thus did he follow it -
"The time will come, that foul sin, gathering head,
Shall break into corruption;" so went on,
Foretelling this same time's condition,
And the division of our amity. (70-74)

The movement from "shall" to "will" is, I take it, a question about the extent to which the second revolt of Northumberland cannot choose but occur. But at the centre of the scene is that other oscillation, between time singular and time plural, between the time and the times: "the time shall come" but also "the revolution of the times." The plural (if one discards the two occurrences as a multiplier) appears an extraordinary fifteen times in 2 Henry IV: times that are "wild," "idle," "rotten," times that "do brawl," lack "trust," belong to "costermongers," times that have a "condition," that mark their change as "revolution," that need to be "construe[d] [...] to their necessities," that will have "after-times," and finally are, in Pistol's erroneous promise to Falstaff, his failed prophecy, going to be "golden."

The scene in which this dialogue is placed is one of Shakespeare's most astonishing moments of dramatic device. Indeed, I don't think there is anything more extreme in drama until Molière's Tartuffe and Beckett's Waiting for Godot. By this point we are nearly half-way through the play (at the start of Act 3) and yet only now does the title-character, Henry IV himself, make his entrance. David Troughton, when he played the king for the RSC in

\footnotetext{
${ }^{5}$ Compare: "Northumberland, thou ladder wherewithal|The mounting Bolingbroke ascends my throne, | The time shall not be many hours of age|More than it is ere foul sin, gathering head, | Shall break into corruption [...]" (Richard II, 5.1.55-59).

${ }^{6} 1.1 .9,2.2 .121,4.4 .60,1.3 .70,1.3 .100,1.2 .170,4.1 .99,3.1 .45$, 4.1.102, 4.1.277, 5.3.97.
} 
2000, used to complain bitterly and not entirely ironically, as he sat for so long in his dressing-room waiting for his first scene, that, dammit all, the play had his name on it. That the scene becomes a reflection or meditation on the processes and continuities of history seems an inevitable outcome of the delay. As Warwick and Henry attempt to create what is in effect a theory of history, they use as their data their recollections of events, their rewriting of history through recharactering the speeches past. Their history is made out of the characters in their plays, the events seen and unseen, events that can be, have been and will be known by playgoers. We characterize their histories through the kinds of histories that we have for them - hence, to take the most obvious example, 1 and 2 Henry IV make different kinds of sense, create different histories and hence different expectations dependent on whether or not we know/have seen Richard II. Our activities as play-watchers are profoundly altered by how we create the character of their histories and the histories of their characters.

But the play of character in a history play is always a matter which in the context of the performance is physicalized as individuals, while the character of history in other circumstances is far more likely to be a play of characters as written traces. Where the written appears in, for example, Henry IV Part 1, it is marked by a functional clarity that is distinctly unlike the material traces of the historical record. When Peto searches Falstaff's pockets and "findeth certain papers," most Prince Henry tells Peto to "keep close" so that they can be "read [...] at more advantage" (2.4.535), items we are later told are "tavern reckonings, memorandums of bawdy-houses" (3.3.157). But one is read out:

Item a capon... 2s. $2 \mathrm{~d}$.

Item sauce... 4d.

Item sack two gallons... 5s. 8d.

Item anchovies and sack after supper 2s. $6 \mathrm{~d}$.

Item bread... ob. (2.4.528-532)

This tavern reckoning is easy to comprehend, its characters read back across the vast bulk of Falstaff and his preferences for more drink than food - and for food like anchovies that stimulate more drinking. We read it against the play's character, Shakespeare's writing of the character, as another sign of its/his characterization. There are aspects of the writing we might want to know more about 
and which editors don't seem to want to help us understand: is that a high price for a capon at a tavern? ${ }^{7}$ Or for sack? The corporation of Stratford-upon-Avon paid 20 pence for a quart of sack and a quart of claret when a visiting preacher was entertained at New Place in 1614. But Shakespeare's audience would have grasped the pricing structures Falstaff's bill represented. As a piece of writing its character is clear. Indeed, it seems to me significant that we give the tavern reckoning a significance in relation to the character. There is no function for it other than as an aspect of Falstaff's dramatic being. It will reappear later as a small item in the plot when Falstaff is claiming that he has lost far more than these bills but, even there, its return is a sign of the individual.

Such writing, in other words, functions as characters about character. And that is exactly what we try to make the material traces of writing about Shakespeare himself mean, that these too can be seen as signs of his character. Virtually everything that constitutes the documentary evidence for Shakespeare himself is in the form of writing. Images of buildings, for example the surviving evidence for New Place, apart, the only other exceptions are, of course, images of Shakespeare and reading them for signs of character is a pretty forlorn activity. When, for instance, Mark Broch and Paul Edmondson writing about the Cobbe portrait, the painting most recently and, I'm afraid, unconvincingly claimed as showing Shakespeare, try to analyse what it "tells us about Shakespeare" and judge that in it Shakespeare "looks self-assured, but relaxed and gentle at the same time. His face [...] open and alive, with a rosy, rather sweet expression, perhaps suggestive of modesty [...]. It is the face of a good listener," I can only wonder that they do not seem to grasp at all how little early modern portraits were representational, how little they were designed to tell viewers about the emotional character of the sitter, how deeply conventional they were (See Broch and Edmondson 2009:22-23). None of the claimed images (portraits and church-monument) enable us to read the "charactery of [his] sad brows."

\footnotetext{
${ }^{7}$ Kevin Quarmby points out that, according to the Corporation of London Records Office Letter Book Y, a table of price controls imposed on the Worshipful Company of Poulters dated 9 July 1577, a "Capon, best," costs "2/-“ (fol. 161v). By 1633-1634, the best capon cost $2 / 6$, suggesting both that inflation was relatively minor even over more than fifty years, and that the cost to Falstaff of capons would hardly seem unusual to a 1590s audience. See Jones (1981:147-148).
} 
Trying to read what the written and printed documentary evidence shows of Shakespeare's character is even more clearly both an expectation in biographical writing and a recipe for disaster. Even the evidence of what he was doing for substantial stretches of his life can be thin. Add up, for instance, the signs that Shakespeare retired to live in Stratford-upon-Avon towards the end of his life. Nicholas Rowe put it in 1709, in the first published Shakespeare biography, that

The latter Part of his Life was spent, as all Men of good Sense will wish theirs may be, in Ease, Retirement, and the Conversation of his Friends. He had the good Fortune to gather an Estate equal to his Occasion, and, in that, to his Wish; and is said to have spent some Years before his Death at his native Stratford. (Rowe 1709:1.xxxv)

But he was in London when the deposition of his evidence in the Belott-Mountjoy case was taken in June 1612 and when he signed the mortgage on the Blackfriars gate-house in London in March 1613. He was there, too, when Thomas Greene called on him on 17 November 1614, this time "commyng yesterday to towne" - but if Shakespeare had come to town from Stratford, why didn't Greene see him there instead? When in September 1611 the town collected subscriptions to cover the costs of lobbying parliament to keep up the highways, Shakespeare's name is added in the margin but whether that indicates, as Schoenbaum hypothesized, that he "was in London when the sponsors first canvassed support" it is impossible to know (Schoenbaum 1975:229). There is, in effect, no hard evidence of Shakespeare's ever having retired to Stratford, let alone that he there lived the life of a man of good sense in Rowe's terms. He made his will there, he died and was buried there and he wrote plays at a slower rate than in the past but that is very nearly all that can be said. The evidence says nothing of his character and, except in the protracted wrangling over the Welcombe enclosures, too complex a matter to open up here, there is little that connects the surviving dots into anything approximating a sequence of interconnectedness, a narrative that might be more than momentarily coherent, indeed, anything that might pass for a narrative at all.

And in that sense, as a sign of what I quoted the $O E D$ as calling "The whole train of events connected with a particular [...] person, [...] and forming the subject of his [...] history," Shakespeare himself has no history, for there is a collection of events but not a "train of 
events," nothing that forms a "subject of his [...] history," nothing to help us shape it other than the sequence of plays, publications, stationers' register entries and such-like regularly occurring information, some of which, of course, is vexingly awkward and imprecise - and I speak as someone who has been wrestling for far too long with the difficult matter of when Shakespeare might have written Coriolanus and when (not to mention where) the play might have first been performed. The pieces can indeed be separated out, as Graham Holderness did when he constructed his Shakespeare biography as Nine Lives of William Shakespeare, each of which is divided into recoverable facts, traditional lore and an imaginative excursus as a short piece of fiction (Holderness 2011).

As textual fragments - both because they are text and because they are fragments of the textualised life of Shakespeare - we can try to read them locally and independently, using those skills appropriate to such material traces, ranging from literary critical or theatrically conscious analysis to philology, palaeography and book history, not to mention social, cultural, local and political history and historiography. We might, this way, get close to deciding whether, say, the signature in the Folger copy of William Lambarde's Archaionomia (1568) is authentic but not to explaining why the signature is so awkwardly written in the ornamental lace border of the title-page, something which Giles Dawson, who does believe it to be authentic, "is inclined to lay to [Shakespeare's] eccentricity" (Dawson 1992:79; see Schoenbaum 1981:104-109). And, in any case, no-one has made any kind of case for the significance of Shakespeare's having owned, let alone read, this compilation of ancient British ecclesiastical law, printed in Anglo-Saxon and in Latin translation, a standard law text for exploring precedents.

Even when scholars try to read the materials contextually, we run into problems. So, for instance, there are the difficulties posed by the Richard Quiney letter of 25 October 1598, the only surviving copy of a letter written to Shakespeare (for, outside the published dedicatory letters to Southampton prefixed to Venus and Adonis and The Rape of Lucrece, there are of course no surviving letters by Shakespeare). Some have wanted to read Quiney's request for help securing a loan for himself and Abraham Sturley of the very large sum of $£_{30}$ to clear his debts as a sign of Shakespeare's being a money-lender, of being like his father, who was prosecuted for 
lending money at usurious rate of $20 \%$ interest, and like his creation of an evil money-lender, of being charactered as both John Shakespeare and Shylock. I find this a misreading of Quiney's letter, for his statement that "I will holde my tyme \& content yowre ffrende" seems clear enough as a promise both to repay by the due date and to satisfy the person Shakespeare would encourage to make the loan, not Shakespeare himself (Chambers 1930:2.102). Shakespeare as intermediary rather than Shakespeare as lender transforms our understanding of the letter. Alan Stewart's superb exploration of it in his hugely enjoyable book Shakespeare's Letters places it into a complex network of letters about loans and other "financial transactions that are forged across two distant places" (Stewart 2008:162; see also Eccles 1961:92-99), many of which survive in the Quiney correspondence that formed part of the Stratford archives after Quiney was killed in a tavern brawl in 1602. And Stewart also places it into an early modern culture of credit arrangements which formed most financial transactions to the extent that, as he quotes Deborah Velenze describing it, "[t]he social import of contractual obligation was so great that all social life was practically indistinguishable from the enforced relationality of trust generated by credit" (Stewart 2008:162).

In spite of the superscription, "To my Loveinge good ffrend \& contreymann $\mathrm{M}^{\mathrm{r}} \mathrm{W}^{\mathrm{m}}$ Shackespere deliver thees," the letter was never delivered, for the sealed document is in the Quiney papers. Schoenbaum assumes it was never sent: "Perhaps Quiney decided to get together personally with Shakespeare; maybe the playwright called on his countryman at the Bell, near St. Paul's" (Schoenbaum 1975:181). But perhaps it was simply not received. Letters were not left in mailboxes but handed to the intended recipient. Certainly Quiney was able to write to Sturley the same day that, as Sturley put it, "our countriman $\mathrm{M}^{\mathrm{r}} \mathrm{Wm}$. Shak. would procure vs monej," but Sturley was hesitant until he heard the details: "which I will like of as I shall heare when, and wheare, and howe" (Chambers 1930:2.103). We have no idea whether the terms pleased and the deal was done, let alone whether it was repaid.

However sensitively we reconstruct the social circumstances of such letters, the letter remains isolated, a gesture towards something that remains resolutely opaque. Of course biographers can make any fragments into a narrative, can, that is, adopt a position in relation to 
the material traces that will control how they are read. To take the most obvious recent example, Katherine Duncan-Jones offered her "scenes from his life" under the title Ungentle Shakespeare and managed to read almost any trace as a sign that Shakespeare was not the gentle-man we might prefer him to have been and that the label of "gentle" he was frequently given by his contemporaries was far from the truth. So, for instance, the will of Thomas Whittington, former shepherd to Shakespeare's father-in-law, bequeathed to "the poore people of Stratford $40^{\mathrm{s}}$ that is in the hand of Anne Shaxspere, wyf unto $\mathrm{M}^{\mathrm{r}}$ Wyllyam Shaxspere, and is due debt unto me, beying payd to myne Executor by the sayd Wyllyam Shaxspere or his assigns" (Chambers 1930:2.42). Duncan-Jones has no doubt that this means that Anne was "left short of money by her husband" and therefore had to borrow money from "her father's old friend" and that Whittington "felt that the poor of Stratford were not receiving sufficient benefit from their celebrated townsman's prosperity;" therefore, "Whittington's bequest delivers a double reproach: the new-made gentleman's son had neglected the needs both of his own family and of the poor of his native town" (Duncan-Jones 2001:150). I suppose it could mean that but the use of a will to mark such a reproach would have been very unusual and not very effective. Where Duncan-Jones sees the 40 shillings as a sign that Anne was short of money, Schoenbaum finds it as likely to be "Whittington's uncollected wages or savings held for safe-keeping" (Schoenbaum 1975:181). Germaine Greer, in her pursuit not of signs of William Shakespeare's ungentleness but of Ann Shakespeare's significance, finds in the statement that the money was held by Ann "a single scintilla of evidence that Ann Shakespeare was economically active in her own right," "operating as a banker," someone who "may have been empowered to lend and spend [her husband's income] as she thought fit" (Greer 2007:220-221).

My point is not, of course, to try to arrive at a solution or even simply to disagree with Duncan-Jones and admire Greer's persistence. Rather, the problem of the fragments are that they cannot be read with assurance, that they are enigmatic in the way that the material traces of history are not in the history plays but that individuals in the history plays are. Just as Shakespeare writes histories, embedding the plays and the characters in them, the figures who figure the history, the ones whose histories make up history, fixing them into what became an unprecedentedly vast 
dramatic narrative of secular life, so Shakespeare's life has in turn become a place to make narrative, the History of William Shakespeare, a potentially "tragical-comical-historical-pastoral" assemblage of genres if ever there was one, in its combination of documentary evidence and the activities of mythography in the long history of writing his history.

I will want finally to suggest a different form of writing of this man's history, one, in effect, more alert to the character of character in its early modern senses. But I want first to suggest that the recent and welcome revival of interest in characters, the turn to character as it were, is still bedeviled by a series of constrictions in the conceptualization of the term that is largely the consequence of considering too few of Shakespeare's characters and hence of a failure to appreciate how the full range of Shakespearean characterization changes the nature of the histories that are being written (see Yachnin and Slights 2009; Holland 1989). The fascinating and provocative essays in Paul Yachnin and Jessica Slights' recent collection on Shakespeare and Character are all about Othello and Hamlet and Macbeth and Shylock but not about the First Senator, the Second Clown, the Third Murderer and the Duke of Venice. Read down a random page of the Index of Characters in Early Modern English Drama created by Thomas Berger and others, and the rich range of characters is far more readily apparent than in any critical writing about character: Shoemaker, Shone, Shopkeeper, Shore, Shorthand, Shortheels, Shorthose, Shorttool, Shortyard, Show, Shrewd Wit, Shrewsbury, Shrimp, Shrovetide, Shrove Tuesday, Shrub, Shunfield, Shylock (Berger 1998:90).

The RS Company that performed the eight-play history cycle in 2006-2008 knew exactly how many characters there were in the plays as they scurried to move from character to character. As V.V. Montreux memorably put it,

"The Glorious Moment:" Thursday $13^{\text {th }}-$ Sunday $16^{\text {th }}$ March, 2008, The Courtyard Theatre, Stratford-upon-Avon. Eight of Shakespeare's history plays in order of the lives and deaths of kings: Richard II, a brace of Henriads, Richard III. Approximately 1,389 minutes of Shakespearean performance in which 34 actors played 264 parts, spoke over 200,000 words, wore over 800 costumes and 40 wigs, wielded 120 weapons and, consequently, spilt over 15 liters of stage blood. In the 71-hours that encompass these performances, the average member of the Courtyard 
audience wears 2.7 costumes and 0.02 wigs, drinks 3.6 liters of coffee, chats up two-thirds of an actor in the Dirty Duck, and tosses 2.1 carnations at the stage in the tumultuous standing ovation on Sunday afternoon. (Montreux 2008:65)

If Shakespeare's histories achieve one thing in their vast recording of history, it is that there are an enormous number of characters needed, characters with histories limited or extensive, stretching across three plays or apparent only in a scene, characters whose lives are richly figured across time and ones superbly sketched in moments, ones that fully unfold over eight hours of performance and ones whose unfolding is immediate and complete. It is a richness that Molly Mahood mapped out for us in Bit Parts in Shakespeare Plays (1992) but whose potential we have too often failed to tap. To think about Henry IV Part I without considering the carters as well as Falstaff is to misunderstand the play's construction of history out of histories. Take some of the roles played by Kieran Hill in the RSC's history cycle-Mayor's Officer, Lord Mayor, Ned Poins, Duke of Orleans, Horner, Earl of Westmoreland - and try to imagine the histories without them. Thomas Whittington is as crucial a character in the History of Mr William Shakespeare as is Anne née Hathaway. Character is not a prerogative defined by length of role and not only kings have histories.

By analogy, some of the greatest achievements of the long, long line of Shakespeare biographies have been the uncovering of the minor characters, the bit-part players in his life history, like those named in his will as recipients of bequests for memorial rings apart from the three King's men: William Raynoldes, recusant landowner, William Walker, Shakespeare's 8-year-old godson, Anthonye Nashe, who collected Shakespeare's tithes and whose son would marry Shakespeare's granddaughter and Hamnet or Hamlet Sadler, who thirty years earlier with his wife Judith gave their names and hence were probably godparents to the Shakespeares' twin children, as they would call their own son born in 1598 William, perhaps another Shakespeare god-son. But there was no memorial ring for Richard Tyler the elder, the butcher's son of Sheep Street, whose bequest was deleted. We can, that is, construct Shakespeare's biography out of the other characters who people it. But I don't think even the alternative form of Hamnet Sadler's first name will tell us much about the creative act of imagination that formed a play about a Prince of Denmark. 
Just occasionally one of these extras in the cast-list of Shakespeare's life seems to reveal something of a movement inwards, from the externalities of character to a process of thought and memory, from an external figure to something that helped Shakespeare figure out how to incorporate a transmutation of that history into a play. I have long been intrigued by one of these moments, one that has had rather less attention than it might deserve. On 6 July 1579 another William Shakespeare, this one of Warwick not Stratford, though fairly closely related to the Shakespeares who did live in Stratford, was "walking to the River [Avon] to bathe himself" when he "suddenly and by accident fell into a deeper part of the River and was drowned" - I quote from the translation of the Latin record of the inquest (Fripp 1930:130). Perhaps Shakespeare heard of his namesake's death, as he might have heard of the suicide of another John Shakespeare, at Balsall, a little further afield the same month.

Perhaps, too, he heard of a second death by drowning a few months later on 17 December 1579 of a young woman baptized Katharine who "going with a certain vessel, in English a pail, to draw water at the river" - the same river Avon but this time in Tiddington, a village a little over a mile from Stratford, in the parish of Alveston on the south side of the river - "standing on the back of the same, suddenly and by accident slipped and fell into the water, and was drowned" (Fripp 1930:129). The death of Katharine, who was not local to the parish, was judged at the inquest under "coroner's quest law" (Hamlet, 5.1.22) an accident, for "not otherwise nor in other fashion came she by her death," and it would not seem significant to me, if it were not for her surname for the poor "spinster" was surnamed Hamlet. I want news of this event to have reached Shakespeare, then aged 15, and I want it to have stayed in his mind and resurfaced from the mess of memories twenty years later as he writes Hamlet and drowns Ophelia and has his clowns discuss whether her death is suicide or not. I want, in other words, for this figure to have imprinted itself, charactered itself into his thoughts so that the record of the inquest becomes a material trace of creative process. I want, rather more than I should, to create a Shakespeare who writes from experiential events, though not as much as Edgar Fripp, on whose account of the inquest I rely, who thought it helped to prove that the young Shakespeare worked in the office of Henry Rogers, the Stratford Town Clerk, Steward and 
Coroner. I do not want to create a Shakespeare who had to have been to Venice to have written Othello or The Merchant of Venice but, paradoxically, I do want a Shakespeare who had picked up that fragment of local news as accidentally as Katharine fell in the Avon.

James Shapiro has been suggesting recently, in Contested Will, his fine account of the anti-Stratfordians, that the principal problem with Shakespeare biographies, including all those many that trust that Shakespeare did write the plays and that there was not some grand conspiracy to use him as front-man for the writing of others, is that we seek to find modes of finding the inner life, the ways in which life experiences transmute into creative writing. Dissatisfied by trying to read, say, Romeo and Juliet alongside Arthur Brooke's Tragicall Historye of Romeus and Juliet we want, like the audiences of Shakespeare in Love, to find in it evidence of Shakespeare's own feelings, not his brilliance at creating representations of feelings. For Shapiro, the great scholar Edmond Malone becomes almost the villain of the narrative of the authorship controversies precisely because Malone in some respects inaugurated the explicit desire to read the works as autobiography. And from Malone to Stephen Greenblatt or Rene Weis or others who want to find what the works have to say about "Shakespeare's inner life," is, for Shapiro, a straight line (Shapiro 2010:265).

Even though there are times this yearning for reading creative writing as autobiography drives me too, I also know that manfully I must try to resist the urge. So, because I can't have that, I want to suggest a way of keeping intact two features of the writing of history, the History of William Shakespeare, that I have been concerned to be identifying: the inevitable discontinuities that the material record of the documentary life manifest and the externalities of the imprint of character and figure as signs of history as personal narrative. Biographical history is a form of parenting that is as brutal in its paternalism as the kind Theseus describes as the potential work of the Athenian father Egeus: Shakespeare, like Hermia, is to us, as to Egeus, "but as a form in wax|By him imprinted, and within his power|To leave the figure, or disfigure it" (MND, 1.1.49-51) - and I feel a shudder of horror every time I think about what "disfigure" means here.

As the characters, the writing of the individual, are imprinted and the figure is left or disfigured, that most violent of images of the 
erasure or damaging of the figure, the external appearance, the identity of the daughter or biographical subject, perhaps we should instead turn to seeing Shakespeare as a concatenation of types and identities, of cultural formulations not of individuality but of the stereotypicalities of recognizability, of the normative rather than the unique, of the undifferentiatedness of the ways in which we perceive social behavior rather than the exceptionality of genius. I offered earlier an extract from a listing of characters in early modern drama. Here is another such list of characters, this time a few from the sequence of "many witty Characters" written by Sir Thomas Overbury and "other learned Gentlemen his friends" (Overbury 1614: title-page), and by others in later editions of the collection and its rivals, characters who might, at different moments and in different lights, in the light both of documentary evidence and of romantic myths of the author, of the materiality of history and the immateriality of our desires, focus the fragmented beings that make up our scholarly and not-so-scholarly creations of his history - and I leave it to my readers to fit these characters to the negative capability not, as Keats thought, of Shakespeare's imagination but of Shakespeare's biography. I end with a list of characters who might be Shakespeare: a dissembler, a golden asse, a flatterer, an ignorant glory-hunter, a tymist, an amorist, an affected traveler, a wise-man, a noble spirit, an old man, a country gentleman, a fine gentleman, an elder brother, a pedant, an ostler, a melancholy man, a distaster of the time, a common player, a rimer.

\section{References}

Berger, Thomas L. 1997. "'Opening Titles Miscreate': Some Observations on the Titling of Shakespeare's Works." Ed. D.C. Greetham. The Margins of the Text. Ann Arbor: The University of Michigan Press: 155-172.

Berger, Thomas L. et al. 1998. An Index of Characters in Early Modern English Drama: Printed Plays, 1500-1660. Revised edition. Cambridge: Cambridge University Press.

Broch, Mark and Paul Edmondson 2009. Shakespeare Found: A Life Portrait. Stratford-upon-Avon: Shakespeare Birthplace Trust.

Chambers, Sir E.K. 1930. William Shakespeare: A Study of Facts and Problems. 2 vols. Oxford: Clarendon Press.

Cockeram, Henry 1623. The English Dictionarie. London. 
Dawson, Giles E. 1992. "A Seventh Signature for Shakespeare." Shakespeare Quarterly 43: 72-79.

Duncan-Jones, Katherine 2001. Ungentle Shakespeare. London: Thomson Learning.

Eccles, Mark 1961. Shakespeare in Warwickshire. Madison, Wisconsin: University of Wisconsin Press.

Fripp, Edgar I. 1930. Shakespeare Studies. London: Oxford University Press.

Goldberg, Jonathan 2003. "Shakespearean Characters: The Generation of Silvia." Shakespeare's Hand. Minneapolis: University of Minnesota Press: 10-47.

Greer, Germaine 2007. Shakespeare's Wife. London: Bloomsbury Publishing.

Hall, Joseph 1608. Characters of Vertues and Vices. London.

Holderness, Graham 2011. Nine Lives of William Shakespeare. London: Continuum.

Holland, Peter 1989. "The Resources of Characterization in Othello." Ed. Stanley Wells. Shakespeare Survey 41: Shakespearian Stages and Staging. Cambridge: Cambridge University Press: 119-132.

Jones, P.E. 1981. The Worshipful Company of Poulters of the City of London, 3rd edn. Oxford: The Poulters' Company.

LEME: Lexicons of Early Modern English <url: leme.library.utoronto.ca>. Last accessed 16/07/2013.

Lieblein, Leanore 2009. "Embodied Subjectivity and the Creation of Early Modern Character." Eds. Paul Yachnin and Jessica Slights. Shakespeare and Character. Basingstoke: Palgrave Macmillan: 117-135.

Mahood, Molly 1992. Bit Parts in Shakespeare Plays. Cambridge: Cambridge University Press.

Montreux, V.V 2008. "32 Short Thoughts about 'The Glorious Moment'." Shakespeare Bulletin 26/4: 65-75.

OED: The Oxford English Dictionary <url: www.oed.com>. Last accessed 16/07/2013.

Overbury, Sir Thomas 1614. A Wife Now the Widow. London.

Paylor, W.J. 1936. The Overburian Characters. Oxford: Basil Blackwell.

Rowe, Nicholas 1709. "Some Account of the Life, \&c. of Mr. William Shakespear." Ed. Nicholas Rowe. Shakespeare's Works. Vol.1. London.

Schoenbaum, S. 1975. William Shakespeare: A Documentary Life. Oxford: Clarendon Press.

1981. William Shakespeare; Records and Images. London: Oxford University Press. 


$$
\text { (a) ederi } 23 \text { (2013) }
$$

Shakespeare, William 1986. The Complete Works. Ed. Stanley Wells et al. Oxford: Clarendon Press.

Shapiro, James 2010. Contested Will. New York: Simon and Shuster.

Stewart, Alan 2008. Shakespeare's Letters. Oxford: Oxford University Press.

Thomas, Thomas 1587. Dictionarium Linguae Latinae et Anglicanae. London.

Yachnin, Paul, and Jessica Slights eds. Shakespeare and Character. Basingstoke: Palgrave Macmillan.

How to cite this article:

Holland, Peter. "'A Kind of Character in thy Life': Shakespeare and the Character of History." SEDERI 23 (2013): 7-31.

Author's contact: Peter.D.Holland.24@nd.edu

Submission: 25/o6/2012 - Acceptance: 28/11/2012 


\title{
Strangers at home: The Textual Construction of the Sherley Brothers
}

\author{
Jesús López-Peláez Casellas \\ Universidad de Jaén
}

\begin{abstract}
During the first half of the seventeenth century various written accounts of the adventures of the three Sherley brothers Thomas, Anthony and Robert - were published in England. These texts, in some cases written by the Sherleys themselves, often contributed to building an unproblematic and positive vision of the three brothers and their adventures in Persia, Turkey, and throughout Europe. However, an examination of the way in which all these texts (pamphlets, autobiographical writings, travel accounts, government documents, and private and official letters) interact with each other, together with the additional information provided by French and Spanish documents not accessible to an early modern audience in England, allows us to retrieve a Sherleyan narrative which, like the period in which it was produced, appears full of contradiction and new meanings.

KEYWORDS: Anthony Sherley, Robert Sherley, Thomas Sherley, seventeenth-century texts, Persia, Turkey, Spain, travel literature, pamphlet literature.
\end{abstract}

\footnotetext{
* The research conducted for this paper was financed by the Research Project "Musulmanes, españoles y judíos en los textos pre-modernos en lengua inglesa: La construccion del otro" (Proyecto I+D ref. FFI2009-13165). I am grateful to the Folger Shakespeare Library (Washington DC) and to the Biblioteca Nacional de España (Madrid) for permission to access their early modern collections. I also thank my friend and colleague Eroulla Demetriou for her valuable comments and careful revision of the original manuscript.
} 


\section{Introduction}

During the early seventeenth century, various written texts of diverse sorts dealing with the adventures and (mostly failed) political projects of the three Sherley brothers, Thomas, Anthony and Robert, were published in England, France and Spain, consequently making knowledge of their exploits widespread. ${ }^{1}$ Indeed, any discussion of the relations of England with Persia (and to a lesser extent with Turkey and Spain) in the early seventeenth century must necessarily consider the narratives of the three Sherley brothers' adventures. These texts, mostly written by participants in their exploits, fashion the Sherleys as typically Elizabethan adventurers endowed with a characteristic and fascinating combination of political ambivalence, boundless ambition, and opportunism. The texts also claim that the brothers' changing allegiances made them serve their Queen (and later their King) with courage until it was in their best interest to shift their allegiance to some other influential power (sometimes serving both English and foreign monarchs simultaneously).

Given their ambiguous relations with England, Protestantism and the Crown, in the eyes of Englishmen of the early seventeenth century they were controversial figures, more to be mistrusted than admired. $^{2}$ On the other hand, Anthony Nixon's well-known pamphlet of 1607, The Three English Brothers, calls them the "three heroes of our time," and complains that the three brothers, being respected figures abroad, were unfairly and cruelly ignored by their own countrymen: "they were unkindly used by us, to be made

\footnotetext{
${ }^{1}$ As we will see, the Sherley brothers became especially popular between 1607 (the date of publication of a first pamphlet and the play about them) and 1613 (when Sir Anthony's own account of his travels appeared in England). However, their popularity did not disappear after 1613: Samuel Purchas was still writing in praise of them in Purchas His Pilgrimes in 1625, and the last eye-witness account of the Sherleys' exploits was published, in French, as late as 1651.

${ }^{2}$ There is sufficient evidence to support this view: their image was so seriously damaged that the eldest brother, Thomas, in 1607 tried to improve it through a pamphlet and a play, both of which he appears to have commissioned (Andrea 2008:45; Masood 2011:168). Also, Anthony Parr has shown how as early as 1602 Thomas and Anthony's expeditions had attracted strong criticism, from among others the letter-writer John Chamberlain (Parr 1996:15). Besides, Anthony Nixon himself, as we will see below, complained about the "unkindness" of contemporary Englishmen towards the Sherleys in his 1607 pamphlet.
} 
strangers here at home" (B-B2). In fact, there is a wide variety of contemporary sources about the three brothers, and whereas some were easily accessible to the English reading public of the age, some others were unknown to most, both then and today. Among the former are a few pamphlets and first-hand accounts, Day, Wilkins and Rowley's 1607 play, ${ }^{3}$ and the Sherleys' autobiographical narratives of their adventures. As for those documents not known by their contemporaries, they include letters by the brothers that were intercepted by the government and filed among state papers, reports by agents working for the various monarchs they served, and narratives and reports by or about them in French and Spanish. This diversity of sources makes it more difficult to determine the Sherleys' real significance in the period and to explain the oblivion into which everything surrounding them fell by the late seventeenth century (Parr 1996:15), including their reputations as "rogue Englishmen:" truculent, ineffectual and disloyal individuals who were inevitably obscured by the "glory of greater men" (Chew 1937:338).

In this essay I will explore most substantially relevant documents by or about the Sherleys (that is, pamphlets, private letters, government reports, and the brothers' own accounts of their adventures), ${ }^{4}$ and I will argue that all these texts offer competing versions of their activities. More specifically, I will read them as instances of early modern discontinuity, ambiguity and paradox which make it impossible for us to retrieve a single and coherent Sherleyan narrative. I will suggest that the non-English versions of this narrative interfere with, and call into question, the propagandistic and apparently harmonic construction of the so called "Sherley myth" (Parr 1996:15). ${ }^{5}$

\footnotetext{
${ }^{3}$ The play is John Day, George Wilkins and William Rowley's, The Travels of the Three English Brothers (1607), which was commissioned by the Sherley family and was heavily indebted to Anthony Nixon's pamphlet of the same year.

${ }^{4}$ I will focus on most of the non-literary sources in English, French and Spanish, leaving aside Persian sources, excluding from my study the 1607 play by Day, Wilkins and Rowley.

${ }^{5}$ Among the non-English sources I will be paying special attention to texts by or about the Sherleys in Spanish. These, apart from constituting interesting material that may contribute, substantially, to our understanding of the actual textual construction of the Sherleyan narrative, are significantly absent from most discussions of the three brothers and their exploits, since there are to date no English editions available.
} 
As Jonathan Burton has argued, in order to approach texts such as these without undervaluing all the non-English components, or reading history backwards, a "historiographical recentering" that problematizes the received histories of imperial continuity is required (2009:27-29). Through this, Burton means "to interrogate established narratives of continuity, or proto-modernization" that have permeated post-Saidian early modern studies on the so-called Muslim other (2009:28). Following Nabil Matar, whose approach emphasises Muslim agency and denies the existence of Orientalist (in the Saidian sense) practices in early modern texts (Matar 1998:120), Burton proposes to compare similar histories (or narratives) in more than one region, without privileging the Western (in our case English) discourse (2009:28). Similarly, I will argue that, if anything, the contradictions we find in the various accounts of the exploits of the Sherleys show how these cross-national discontinuities operate. Furthermore, I will highlight how all these sources, with their conflicting versions as well as complementary interpretations, not only illuminate the Sherleyan narrative as an instance of early modern intertextuality, a Genettian palimpsest (or the Lotmanian semiosphere, a space of semiosis - Lotman 2001:126-131), but also address the complexity of the notion of the global early modern ${ }^{6}$ that the Sherleys, more than most, exemplify.

\section{2. "Heroes of our Time"}

More than any other text (with the possible exception of Day, Wilkins and Rowley's play, which was closely based on it), Nixon's pamphlet The Three English Brothers (London, 1607), was designed to foster the Sherleys' reputation as:

worthy personages whose Noble spirits [...] have drawn other Nations into admiration of their valours and emulation of their

\footnotetext{
${ }^{6}$ I use this notion, which I borrow from Jonathan Burton, to refer to the so-called New World History's current emphasis on reexamining the discourse of Eurocentrism, interrogating "established narratives of continuity, or proto-modernization" (2009:28) and refusing to privilege European (the English sources of the Sherleyan exploits, in our case) categories. See for example the collection of essays recently edited by Jyotsna G. Singh, A Companion to the Global Renaissance: English Literature and Culture in the Era of Expansion, which explores how "English literature and culture of the period [...] are clearly imbricated within the larger imaginings of the 'worlds elsewhere,' which were brought home via a new cosmopolitanism" (6).
} 
virtues, [...] the Three Heroes of our Time; [...] Honour by them has added to her [i.e., England's] glory. (Nixon 1607:B-B2)

Anthony Parr convincingly argues (as Chew had already claimed) that Nixon's text was probably commissioned by Thomas Sherley (the eldest brother) in December 1606, soon after his return to England from his two-year imprisonment in Constantinople (Parr 1995:6; 1996:18; Chew 1937:287-288). Such a propagandistic text was apparently necessary because, during this period (late 1580s to 1607), the three brothers had been involved in dubious enterprises ${ }^{7}$ around the world (Parr 1996:15), calling into question the nature of their allegiances to various monarchs. Furthermore, the two youngest brothers - Anthony and Robert - had become Catholic from about 1598-1600 (Chew 1937:271), and Sir Thomas Sherley the elder had additional financial and legal troubles. Consequently, the family's name was far from untarnished (Schleck 2011:61-93).

From a more political perspective, Nixon's pamphlet was also devoted to promoting Anthony and Robert's attempt, after their arrival in Persia in December 1598, to encourage a Christian-Persian alliance against the Ottomans. Hence the pamphlet could be defined as an "interventionist" text, that is, one that is intended to influence public opinion on a current issue. ${ }^{8}$ Consequently it focused on the so-called "Persian adventure" of Anthony and Robert between 1599 and 1601 (the embassy that took Sir Anthony and an Anglo-Persian contingent to various European courts on a diplomatic mission) together with Thomas's Mediterranean campaign and subsequent imprisonments in Negroponte and Constantinople.

\footnotetext{
7 Sir Anthony narrates many of his (eventually unsuccessful) plans for a Spanish readership in Pesso politico de todo el mundo (Madrid, 1622), which recounts his fruitless embassy in Barbary on behalf of Emperor Rudolf, his participation in a failed AngloMoroccan plan to attack Spain, his role in promoting the marriage between Mary Stuart and the Duke of Parma in the late 1580 s, and his self-proclaimed active proSpanish role in the attempted Armada invasion (163-169v). Thomas's infamous Mediterranean raids on peaceful villages (1598-1602), and Robert's Persian marriage and eventual employment as the Sophy's ambassador (from 1599) also added to a generalized skepticism about the three brothers' merits and allegiances (T. Sherley 1936:iii-xii; Shand 1983:257-258).

${ }^{8}$ I borrow the term from Laurence Publicover, although he specifically applies it to Day, Wilkins and Rowley's play (Publicover 2010:695). Publicover holds that the play is part of a "public relations campaign" defending a "controversial political programme" (2010:695).
} 
Nixon's pamphlet was not original either: it was based on information provided by the eldest brother, Thomas Sherley (from his diary, preserved at Lambeth Palace), and especially on eyewitness accounts of various episodes of the Persian expedition, written by actual participants who, being in the service of Anthony and Robert, mostly praise them as exemplars of English virtue, courage and wit. These texts are the anonymous A True Report of Sir Anthony Sherley's Journey (160o); William Parry's A New and Large Discourse of the Travels of Sir Anthony Sherley, Knight (1601); and George Manwaring's A True Discourse of Sir Anthony Sherley's Travel into Persia (1601). From these direct sources Nixon literally lifted whole passages. ${ }^{9}$ Other documents about the Sherleys dealt with the Persian adventure, though they were not in English, or contemporary to the events described, or both. Consequently, while they also contributed substantially to the construction of the Sherleyan narrative, these other documents neither had a direct influence on Nixon or the play, nor became as popular as either. These documents are the autobiographical Sir Anthony Sherley. His Relations of his Travels into Persia (1613); John Cartwright's The Preacher's Travels (1611); Abel Pinçon's Relation d'un voyage de Perse (composed in 1605, though not published in Paris until 1651); and the illuminating Relaçiones de Don Juan de Persia (Madrid, 1604), by a certain Uruch Beg, who, after converting to Catholicism in Spain, became Don Juan de Persia. As we will see, both Pinçon's and Don Juan's narratives (especially the latter), unknown in England during at least the first half of the seventeenth century, interrogate the positive picture of the Sherleys, especially that of Sir Anthony, provided by English sources.

Of all these documents, Relaçiones is clearly the most interesting. Written by one of the Persian secretaries of Huseyn Ali Beg, the ambassador of the expedition, it was originally published for a Spanish Catholic readership and was completely unknown in early modern England, a fact which explains its invisibility for Nixon, Parry, Manwaring, or the three playwrights. Sir Anthony was lucky this was so, since in his account of the failed embassy of 1599-1601 Don Juan/Uruch Beg portrays Sir Anthony as a charlatan, liar, and murderer. Furthermore, he reduces Anthony's participation to a very

${ }_{9}^{9}$ Compare, for example, Nixon ( $\mathrm{H}_{4}-\mathrm{I} 1$ ) and Thomas Sherley's Discourse (1-2), with literally identical phrasing describing the Turks. 
marginal role, in marked contrast to the English texts. Indeed, Nixon's laudatory pamphlet was simply following similar (earlier) narratives. Thus, the anonymous True Report praises Sir Anthony for the "Free privileges obtained by Sir Anthony Sherley of the Great Sophy for all Christians to trade and traffic into Persia" (Ross 1933:96); Parry describes at length the Shah's admiration, bordering on infatuation, for Sir Anthony (Ross 1933:116-120); and Manwaring presents him as a leader who, while travelling through Persia, "desired to endure any torments himself, so that his company might pass quietly without hurt" (Ross 1933:193). It is against this consensus on the heroic stature of Anthony Sherley that we may read Don Juan of Persia's Spanish narrative.

Don Juan, who is not especially interested in the figure of Anthony Sherley (evidently his text has a different goal), unambiguously claims that he "had always had a mind to get the better of us" (Persia 1926:261), and provides some descriptions of Sir Anthony Sherley which interrogate the standard narrative of a heroic and honourable English hero. The episode concerning the disappearance of a friar provides a good example of this conflicting discursive production of Sir Anthony:

It was our suspicion that Sir Anthony Sherley had made away with him, for at the time when we were voyaging up the river Eder in the galleys, he had often threatened to kill the Friar, and for a time had kept him prisoner down below decks in a cabin of the galley. [...] For the Friar had explained to us that he had lent Sir Anthony a thousand crowns, and further entrusted him with ninety small diamonds to keep safe for him, and that it was because he had wanted these and the money back from Sir Anthony that he was so treating him to compass his destruction. (Persia 1926:258)

Comparing the English propagandistic texts with Don Juan's (proSpanish) unsympathetic description of Sir Anthony's wretchedness and petty machinations during the embassy (which ranged from grossly stealing the Shah's gifts to the Pope, to probably killing the friar, to whom he apparently owed some money) complements our understanding of the transnational Sherleyan narrative by providing us with a complex and unexpectedly rich mosaic of the multiple identities of Anthony Sherley which his English contemporaries lacked. 


\section{The Persian adventure}

Don Juan's narrative, as has been stated above, basically dealt with the so-called European (or Persian) embassy, the adventure for which the Sherley brothers were mostly admired in the early seventeenth century, and remembered for decades after. This embassy $^{10}$ apparently had the intention of, firstly, promoting commercial relations with Persia and, secondly, persuading Shah Abbas (who was known in early modern England as the Great Sophy) to join Christendom in a military league against the Turks. This league, Sir Anthony apparently suggested, should combine the forces of the Habsburg monarchs, Venice, and the Pope (Chew 1937:250; Burton 2009:23-24; Publicover 2010:699-700). Neither of the two goals was successfully accomplished or pioneering (Chew 1937:225-237,266-269); as a matter of fact, Elizabeth had officially decided to begin commercial relations with Persia as early as 1561, having sent a number of letters to the Shah to that effect (Hakluyt 1903:III, 7-8). However, from the 1580 os England had embarked on a policy of friendship with the Ottomans by means of the Levant Company, and consequently trade agreements or military alliances with the Sophy were now subordinated to the changing interests of Elizabethan England's politics (i.e., a strategic approach to Turkey, Spain's major enemy) (Chew 1937:250). With the accession of James I to the throne, the overtly friendly attitude towards the Porte was utterly rejected to the extent that even to communicate with the Turks on matters of commerce was forbidden. Additionally, as early as 1601, even before he had succeeded to the English throne, James was already trying to side with the Persians in their intermittent military conflicts with the Ottomans; this, however, had little impact on the Persian adventure since by late 1602 what remained of the embassy was already back in Persia (Jones 1978:163-168; Dimmock 2005:3-4,141; McJannet 2009:147-155; Chew 1937:277-278). The second goal that the Sherleys pursued, namely the creation of a combined Christian-Persian military front against the Turks, was grounded on the religious enmity existing between the Persians,

\footnotetext{
${ }^{10}$ The embassy included, apart from Sir Anthony (Robert Sherley stayed in Persia with the Sophy as a hostage): William Parry, George Manwaring, and Abel Pinçon plus four other Englishmen, the Persian ambassador Husayn 'Ali Beg, his four secretaries (one of whom was Uruch Beg, later Don Juan of Persia), and two Portuguese friars: the Franciscan Alfonso Cordero, and the Augustinian Francisco de Melo (Ross 1933:22; Chew 1937:261-264).
} 
who were Shi'ites, and the Turks, who were orthodox Sunnis, as we will see.

According to his autobiographical account, Sir Anthony's plan, unaware of (and almost uninterested in) late Elizabethan foreign policy, consisted of uniting all Christian princes and joining them to the Persian Sophy in order to confront the Turks (A. Sherley 1613:8083). Significantly, all English sources agree in describing this project as entirely engendered by Sir Anthony. According to Parry, "Sir Anthony ceased not to animate him [the Sophy]" and "possessed the King with [...] a burning desire to invade the Turk's dominions" (Ross 1933:118). Manwaring gives a similar, if only slightly more detailed, account:

Sir Anthony altered the King's mind, persuading him to send to all the princes in Christendom, which he was assured the Queen would like well of and to be in league with them all, and he would undertake to accomplish the embassage; and, moreover that he would maintain wars against the Turk on that side of him, and he would work so with the Christian princes that they should maintain wars on the other side, and so by that means overthrow him. The which matter the King was exceeding glad of, giving Sir Anthony many thanks for his good invention. (Ross 1933:222-223)

Abel Pinçon also presents the Persian-Christian alliance as Sir Anthony's "good invention," for which the Sophy was "exceeding glad of" (Ross 1933:223). Nixon summarizes this project, which he also attributes to Anthony Sherley:
Sir Anthony ceased not, during the time he lay in the Cittie, by all importune meanes, and forcible reasons, to animate and incense the Persian: alleaging how easy a matter it were for him, by his meanes, being a Christian, to joyne many of the Christian princes, his borderers, in League and friendship with him, and draw them to the assistance of these wars, both his supply in his owne Countrey, and als with powerfull invasions in many other places of the Turkes dominions, farre remote. $\left(1607: \mathrm{H}_{3}\right)$

Don Juan of Persia, however, gives a significantly different version of this event: "to this end, namely, war with the Ottoman power, the timely arrival of certain Englishmen gave him [ie, the Sophy] much encouragement" (Persia 1925:227). The project, according to Don Juan, had already been conceived by the Sophy, and the English brothers simply "arrived in the very nick of time," for the Sophy was already "preparing to send an ambassador with many gifts to the 
king of Spain, by way of the Portuguese Indies" (Persia 1925:232). Don Juan's account, then, clearly disputes Sir Anthony's claim to having played a central role in this high political decision.

This project was not, in any case, supported or inspired by the English (Elizabethan) government, which - as we saw above - was at the time (1598) eagerly trying to negotiate with the Ottomans against their common enemy, Habsburg Spain, a diplomatic move that, as I explained, would soon change under the Stuart monarch (Bak 1996:212-216). There is some evidence of the discomfort with which England followed the Sherleys' projects in Turkey and Persia: we know that William Cecil instructed the English ambassador at the Great Porte, Henry Lello, to discredit Sir Anthony in October 1600 as a rebel who had been "reproved in England for his folly" (Chew 1937:267). Furthermore, Sir Anthony was closely watched as an "impudent and inconvenient adventurer who [...] [had] arrogated to himself the title of English envoy to Persia," as Chew explains (1937:266). Indeed, it seems that Sir Anthony had actually proceeded in such a way, although no English narrative on the Sherleys makes any reference to it. Importantly, it is again from Don Juan that we learn that

He [Sir Anthony] gave himself out as cousin of the Scottish king James, saying that all the kings of Christendom had recognized him as such, and had now empowered him as their ambassador to treat with the king of Persia, who should make a confederacy with them in order to wage war against the Turk, who was indeed the common enemy of all of them. (Persia 1926:232) ${ }^{11}$

But "English envoy to Persia" was not the only title that Sir Anthony gave himself, as it appears that his claim to be the Sophy's ambassador and leader of the European expedition were not true. According to the Calendar of State Papers. Colonial Series, "in 1599 Shah Abbas sent over by Sir Anthony Sherley a declaration of his desire to be at peace with the Christian Princes" (1964:263/103). Manwaring actually explains how, after the Sophy invited Sir Anthony to lead his embassy to Europe, it was Sherley who "request(ed) the King to send a Persian along with him" (Ross 1933:223), and Nixon makes clear that Sir Anthony was the

\footnotetext{
${ }^{11}$ Furthermore, according to E.P. Shirley, Henry Lello wrote to Cecil in August 1598 that Sir Anthony Sherley had requested from him a passport, falsely claiming to be on business for Queen Elizabeth (1848:17).
} 
ambassador (Nixon 1607:H3-H3v). However, some non-English accounts seem, again, to dispute this. Don Juan affirms that the Sophy gave orders "proposing that Sir Anthony should accompany his envoy the Persian ambassador" (233), and Pinçon, for his part, simply says that "the Sophi sent him [Anthony Sherley] back to Christendom with one of his nobles, bearing presents and letters" (Ross 1933:164). Although his precise role in that embassy is, to this day, unclear, it appears that the official ambassador was the Persian nobleman Hussein Ali Beg, and that Sir Anthony's role was intended to be subservient to his, if only because the Shah was an experienced ruler, Ali Beg a trustful courtier, and Sir Anthony a foreigner newly arrived in Persia (Burton 2009:32-37; Gil 1985:352,366-368). Yet English sources endeavoured to present Anthony (and to a lesser extent Robert) Sherley as both the instigator of this embassy and its leader.

Anthony Nixon's text also claims that the Sophy, who according to Nixon liked Sir Anthony's project and trusted him, resolved to commission Sir Anthony - essentially on account of his being a Christian - to go to Christian courts to propose this league (1607: $\mathrm{H}_{3}-$ $\mathrm{H}_{3 \mathrm{v}}$ ). Interestingly given the Sherleys' uncertain religious allegiances as Protestant and Catholic, it would seem that it was Sir Anthony's Christian identity that convinced the Sophy to make him an important member of the embassy. According to the writings of Alfonso Cordero, one of the two Portuguese friars also travelling with the embassy, neither Shah Abbas nor Ali Beg, the Persian ambassador, had a clear idea about which European courts to visit: as Cordero puts it, the Sophy did not know "qué sea Inglaterra, ni Flandes, ni tiene más noticia que los títulos" (qtd in Gil 1985:352). Consequently, he needed Sir Anthony on account of his alleged knowledge of European courts.

But if, for the English, the Persian adventure could be described as controversial because it involved an alliance with a non-Christian nation, the simultaneously ambiguous and popular nature of this exploit, that evidently captured the imagination of the Elizabethans, must have had much to do with Sir Anthony's disturbing connections with the Earl of Essex (Ross 1933:8-10). To this we must add some of Sir Anthony's crucial decisions, namely why he never returned to England from Venice to support Essex's ill-fated plot, and why he decided, instead, to proceed to Persia in 1598, in both 
cases apparently following direct orders by the Earl or led by obscure motives, (Ross 1933:12-13; Chew 1937:239-242). Indeed, Sir Anthony's autobiographical writing of 1613 contributes to this confusing and somewhat mysterious narrative about the reasons behind his voyage to Persia. While according to Parry and Manwaring (Ross 1933:176) the idea of going to Persia came after conversing in Venice with a Persian merchant and an Italian translator, Sir Anthony's own account gives very different reasons:

Hee [Essex] proposed unto me (after a small relation, which I made unto him from Venice) the voiage of Persia, grounding of it upon two points. First, the glory of God. Then, [...] by making a profitable experience of my seeing those Countries, limitting upon the King of Spaines small parts, and answering to her Majesties Merchants trades in Turky, and Muskovy. [...] Besides, some more private designes, which my fortune, being of the condition, which my persecutions have brought it into, counselleth mee not to speake of. (A. Sherley 1613:4-5)

To my knowledge, Sir Anthony does not explain anywhere what that "small relation" he sent to Essex was about, what the "private designes" that sent him to Persia were, or why his current situation "counselleth" him "not to speake of" them. What Anthony Sherley does argue is that his relationship with Essex had condemned him, and that, if he had followed the Earl, it was "constrained by extremest necessity," as he complains in a letter to Cecil that predates his 1613 narrative (Calendar of State Papers. Domestic 1601-03 1870:223). After recounting his many services to England, he claims:

but all has been lost with one man. I wish my actions to be considered apart from the Earl of Essex, and to be judged by their merit. I hear of no one whose affection to the Earl has proved so pernicious to himself as has mine, though furthest removed from him. (Calendar of State Papers. Domestic, 1601-03 1870:224)

In another intertextual twist, and obviously aware of the inevitable associations between the Sherleys and his one-time patron the Earl of Essex, Nixon (in his account of Sir Anthony's "adventures and voyage into Persia") introduces a useful and equally intriguing comparison between Anthony Sherley and that Elizabethan paradigm of treachery, Captain Thomas Stukeley. Stukeley had become for the early modern English mind the quintessential traitor, the antithesis of the sixteenth and seventeenth centuries' concern with honour and reputation. This sharp contrast immediately 
introduced an additional textual layer of significance in the Sherleyan narrative: whereas Anthony Sherley is defined by Nixon as having "principally before him the prospect of honour," Stukeley only has "his desire upon a luxurious and libidinous life;" and whereas the former has "inlarged" his fame by means of "his honourable plots and imployments, against the enemie of Christendome," the latter is characterized by "treacherous designes [...] on behalf of the Pope, against his countrie" (1607:G1v). This emphasis on Anthony's loyalty through his contrast with a notorious traitor such as Stukeley evidently responds to the author's need to address the controversial matter of both Anthony's and Robert's recent conversion to Catholicism, of which readers must have been aware, most especially in the context of the Sherleys' involvement with Essex. This paradoxical and somewhat confusing triangular relation between the figures of Essex (originally a man of repute, eventually a man condemned), Stukeley (evil through and through) and Sir Anthony (whose reputation was in the (un)making) can only be explained by reference to Elizabethan honour in its various forms: military, chivalric, public and private (James 1978:309-325). Essex through his eventual revolt - represented the decline of some Elizabethan symbols linked to honour, ${ }^{12}$ and thus Stukeley is introduced in order to clarify (by contrast) Anthony Sherley's position vis-à-vis these two other controversial figures to whom Nixon knew - an early seventeenth-century reading public would relate him.

\section{Constructions of the Muslim world}

Although the idea of a Persian-Christian political and doctrinal alliance against the Ottomans appears central to several texts on or by the Sherleys, it was - perhaps surprisingly - not the major concern in Nixon's pamphlet. Certainly, Nixon reproduced the standard early modern descriptions of the Great Sophy as a Muslim ruler who favoured Christians: according to Manwaring, the Sophy

\footnotetext{
${ }^{12}$ Essex represented the epitome of "old honour" until his failed rebellion (the "last honour revolt," as James put it, 1978:416) disgraced him; this honour was identified with aristocratic values such as a strong emphasis on martial deeds, a direct connection with blood ("honour by nature") and "nobility" as a synonym for honour, and opposed the emergent Bartolan concept of honour ("honour by nurture" or merit) that would develop in the seventeenth century (James 1978:405-415).
} 
was "almost a Christian in heart" (Ross 1933:225), and Nixon, recalling Robert Sherley's life in Persia, explains that the Sophy "tends such attentive care [to Christianity] [...] that he [Robert] doubteth not [...] he [the Sophy] may in time bee brought to become a Christian" (Nixon 1607:K4v). "Abel Pinçon also testifies to the Sophy's kindness to Christians: "He [Shah Abbas] is very gracious to strangers, specially to Christians" (Ross 1933:158).

In this respect, Anthony Sherley also appears to emphasize how, unlike the Turks, Persians were inclined to favour Christians: "He [the Turk] is an absolute and Tyrannous enemie to the Christians: Your Majesties Religion hath a charitable opinion of them [Christians]" (A. Sherley 1613:117). Although we should remember that Anthony is reproducing here what he seems to have said to the Sophy himself, it is still noteworthy how this opinion will significantly change less than a decade later, in his Spanish political treatise of 1622 Pesso politico de todo el mundo. There, Sir Anthony expresses a quite contrary vision of Persian attitudes towards Christians:

El Persiano tiene naturalmente más aborrecimiento a los christianos que no el turco, y lo que digo es demonstrativo pues que el turco a admitido siempre y admite conventos de religiosos y algo de espacioso término en sus estados a los christianos pero el Persiano nunca lo a hecho hasta que esta ocasión de rompimiento con el turco traxo el negocio a necessaria [...] y forzada conveniencia. $(83 \mathrm{v}-84)$

As I have shown, a strategic coalition between Persians and Christians to confront the Turks certainly appears as a possibility in the writings of Pinçon and Manwaring, albeit not on account of the Sophy's alleged sympathy towards Christians but because of the hostility that they perceived between Persians and Ottomans. This hostility - these authors claimed - was based on religious (sectarian) differences. Manwaring is very specific when referring to these dissensions within Islam: "as the Turks do hold the kindred of

\footnotetext{
${ }^{13}$ According to Manwaring the Sophy once said: "I do esteem more of the sole of a Christian's shoe, than I do of the best Turk in Turkey" (Ross 1933:208). But contemporaries of the Sherleys knowingly dismissed this idea as absurd: the notion of the Sophy as a potential convert to Christianity was, according to Cartwright, "more fitte for a Stage, for the common people to wonder at, then for any mans private studies" (Cartwright 1611:70-71).
} 
Mahomet in great reverence amongst them, so the Persians do contrary unto them" (Ross 1933:217). Pinçon, for his part, remarks that "the Persians hold the Turks in great abomination, saying that they are impure in their law" (Ross 1933:163). Also, Nixon explains this hatred in an insightful way:

The Persian praieth to Mahomet, and Mortus Ally, the Turkes both to them and three others, that were Mahomets servants, against which three, the Persian still inveighs, and is an enemie. (Nixon 1607:H2-H2v)

Through his reference to "Mortus Ally" Nixon is here showing the sophisticated knowledge of Islam that the Sherleys had. Indeed, the pamphleteer was developing, for an early modern English readership, some of the complexities of this religion by alluding to its two main branches: the Shi'a denomination, which was predominant in Persia, and the Sunna branch, the official version of Islam in Turkey. These sectarian differences were already known in England since the 1560s (Masood 2011:5-6), although what Manwaring, Pinçon or Nixon seem to be expressing is how "sectarian divisions within Christianity and Islam were thought to be interconnected, and how Catholic-Protestant-Shi'a-Sunni interests diverged and converged in the early modern world" (Masood 2011:6); this dissension, they implied, could favour the Sherleys' military and political projects (Ross 1933:162-163).

Stemming from these religious differences, the various narratives on and by the Sherleys elaborate on the possibilities of making these two powerful kingdoms confront each other. To achieve this, the English readership had to be persuaded that, firstly, the Ottomans were "the most inhumane of all other barbarians" (T. Sherley 1936:1) and that, secondly, they were "a shaddowe of greatness whyche former tymes have given him" (5). All three brothers (but especially Sir Anthony) attempted to present a convincing case for Persian interest in joining Christendom in such an alliance. For Nixon:

There are two sorts of Turkes: the natural Turke and the Renegado [...] and they are and have beene ever the most inhumane of all other Barbarians. Their maner of living is for the most part uncivill, and vitious. For their vices, they are all Pagans, and Infidels, Sodomites, and Liars [...] their pride is so great, as it is not possible to be described. Next that, followeth their crueltie, in which their kings exceed [...] The Turkes are beyond all 
measure, a most insolent, superbous, and insulting people, ever prest to offer outrage to any Christian. (Nixon $1607: \mathrm{H}_{4}-\mathrm{I}_{1}$ )

Nixon also states that, due to their decadence it would be easy for a league of Christian princes to defeat and convert them (Iiv). Sir Anthony, in his own narrative, expresses similar criticism of the Turks as he states that their power is declining due to their great corruption and hedonism, as the many successful rebellions taking place within the Ottoman empire prove (1613:105-115) ${ }^{14}$ In fact, in a long letter to Sir Robert Cecil in which he tries to excuse his behaviour between 1597 and 1601 (plotting against pro-Turkish English foreign policy), Sir Anthony tries to justify his support of the Persians by alluding to the Turks' alleged weakness:

The Turk being a friend to the Queen for State reasons, it may be asked why I moved the Persian against him, without Her Majesty's licence. It was because the Turk only favours the Queen for the sake of our trade [...] this amity is not useful, for his government is very weak; he cannot move the King of Spain, nor the Venetians, who are suspicious of him, to arms; and he could not put 50 galleys to sea. (Calendar of State Papers. Domestic, 160103 1870:223-224)

Sir Anthony also adds some hyperbolic praise of the Persians, in a clearly ideological attempt to justify his belief in the coalition he was trying to build

the fashion of his [ie, the Sophy's] governmêt differing so much from that which we call barbarousnesse, that it may justly serve for as great an Idea for a Principality, as Platoes Common-wealth did for a Government [...] The King gives the notablest example of true unpartiall royall iustice, that I thinke any Prince in the world can produce. [...] This king wee call barbarous, though from his example wee may learne many great and good things. (A. Sherley 1613:29; 67; 70)

But here we find, once again, how Sir Anthony's narratives can, after only a few years, easily contradict themselves in a substantial way. References to Persian greatness almost disappear from the description of Persia appearing in his Spanish Pesso politico de todo el mundo. Addressed to Philip IV's main counsellor and royal favourite,

${ }_{14}$ Thomas Sherley's Discourse of the Turks (ca. 1607-1608) is almost exclusively concerned with criticism of the Turks. Interestingly, Nixon's description of the Turks in $\mathrm{H}_{4}$ is almost identical to Thomas' on the first page of his treatise. 
the Count-Duke of Olivares, Pesso presents Persia as a hybrid community composed of "naturales persas" and "Turcomanos, Curdos y Tártaros," the latter being a majority of "Bárbaros inconsiderables [...] soberbios y en fin gente sin manera de ley" (80); they are also weak and inferior to the Turks ("desigualísimo al Turco" 82), and, as we saw, in no way may they accept Christians: "El Persiano tiene naturalmente más aborrecimiento a los christianos que no el turco" $(83 \mathrm{~V})$. This, of course, contradicts other judgments made by the Sherleys and his companions, which presented the Persian Sophy as "almost a Christian in heart," as Manwaring expressed it (Ross 1933:225), and Persian religion as closer to Christianity than the Turks' (A. Sherley 1613:117).

Evidently, Sir Anthony had good reason to act in this way: if by the time he wrote his autobiography he was interested in explaining to an English readership why he had gone rogue and become a Persian "ambassador" (never acting as an English envoy, although pretending to be one), in the 1620 s in Spain he tried to present his Persian adventure from the perspective of the risks involved for him when dealing with such "Bárbaros inconsiderables" (A. Sherley 1622:80), as well as the services he had rendered to Habsburg struggles against the Ottomans. His brothers were equally involved in similar activities of an uncertain political nature which they endeavoured to present in a positive light: Thomas Middleton's 1609 pamphlet Sir Robert Sherley was an attempt to convince its readership that Robert, who in fact was a pensioner of the Sophy, was acting in order to improve the influence of England in Persia; to that effect, Middleton made Robert's Persian mission "more palatable to the intended English audience" by removing from his pamphlet references to Robert's Catholicism, and excising allusions to his loyalty to Persia (Shand 1983:260). As for Thomas, his own pamphlet shows how, for all the hatred expressed, he did not return to England directly as soon as he was freed in Constantinople, but stayed there and, on returning to England in 1606, unsuccessfully tried to establish commercial relations with those Ottomans he had so bitterly demonized in his Discours of the Turkes (Ross 1936:3-15). 


\section{Conclusions: The Sherleys, England, and the Global Early Modern}

The Sherley Brothers were, by the late sixteenth century, alienated from their home country. Whereas Thomas returned to England in 1606, and Robert spent all his life as a Persian subject, periodically travelling through Europe as a genuine ambassador of the Great Sophy, ${ }^{15}$ Sir Anthony would never again set foot in England after 1597. King James's representative in Venice gave the Venetian ambassador a brief and only partial explanation of this:

[Sir Anthony Sherley] had not returned to England after his voyage to Persia for no other reason than that as a relation and dependent of the Earl of Essex, he would have been exposed to persecution by the opposite faction after the Earl's death. (Calendar of State Papers. Venetian 1603-1607 1900:35)

Albeit after the accession of James Stuart it could be thought he had nothing to fear, as Sir Anthony himself complained, the ghost of Essex seemed to haunt his life. Indeed, this statement was made when Sir Anthony - for reasons unclear to this day - had already decided not to return to England and enter into the service of various foreign monarchs: twice expelled from Venice, he served the Habsburg Emperor in Prague (who sent him to Morocco in 1605), ${ }^{16}$ and Philip III of Spain from 1607. As I noted above, in his Spanish treatise Pesso politico de todo el mundo Anthony Sherley affirmed that he had played an important role in the political plotting preceding the Armada failed invasion of 1588 , carrying letters (the content of which he claimed to know) between Mary Stuart, the Duke of Parma and the Earl of Leicester:

La carta de la reina de Escocia hera brebe pero apretada en el punto de remitirse en todo a la del Conde de Lexest [Leicester] [...] La carta del Conde hera amplia, y copiosa, tratando de muchos disgustos, que tenia con la Reina de Ynglaterra [...] y que

\footnotetext{
${ }^{15}$ Before his death in Persia in 1628 Robert had visited England twice, and he was received as the Sophy's ambassador by King James in 1611 and 1624, and briefly by King Charles in 1625.

${ }^{16}$ There is not much information about Sir Anthony's adventures in Morocco, although Robert Chambers's True Historicall Discourse of Muley Hamets Rising (1609) gives a succinct account of "the aduentures of Sir Anthony Sherley, and diuers other English gentlemen" (1609:front page). The Folger Shakespeare Library Hamnet catalogue gives a certain R. Cottington as possible author of this book, leaf A2r is signed Ro. C.
} 
si el Duque [of Parma] quisiese hacerse rey de Ynglaterra, al qual reino tenia un cierto derecho suio propio [...] tendria sus fines la intenzion de el rey de España aunque por otro modo, pues que el reino de Ynglaterra seria de Prinzipe siempre amigo y pariente suio. (A. Sherley 1622:164-164v)

In 1607 King Philip conferred on him the title of "Count" (he is called "Conde Antonio Xerly" in some Spanish documents of the 1620s) and he received a commission as "General of the Mediterranean sea" to fight Turks and Moors (Ross 1933:68-69), ${ }^{17}$ but he eventually failed in this capacity, in which he continued his selfassigned life mission, namely to unite all Christian princes against the Turks (Chew 1937:282-297,289). Yet as early as 1610 he had already fallen into disrepute with the Spaniards and was living, if not in poverty, certainly with modesty, a condition from which he would not recover, dying obscurely in Madrid in 1637 (Shirley 1848:98-100; Chew 1933:296-297; Ross 1937:84-85). ${ }^{18}$

The contradictory allegiances and troubled lives of the three Sherley brothers (especially of Sir Anthony's), and more specifically the various accounts of their lives and adventures, invite, as we have seen, an approach that conjoins early modern ideology, politics, and textuality. The conflicting versions of Sir Anthony and Robert's Persian embassy, their connections (never clarified) with Essex, King James or the Sophy, or the uncertain and often contradictory views of Persia and Turkey offered in these texts, are inextricably bound up with the (literally) textual construction of the adventures of the three brothers. From Nixon's encomiastic pamphlet to Don Juan's merciless description of Anthony's lack of ethics, from Anthony's and Thomas' self-aggrandizing autobiographies, and Parry's and Manwaring's sympathetic accounts of the former, to Pinçon's more detached (but nevertheless partial) depiction of the same events, all these texts conflict and permeate each other in a constant interplay of fact and fiction which eventually seems to suggest that a noncontradictory Sherleyan narrative is irretrievable. In the blurred and ambiguous writings of these three Elizabethan adventurers, English nationhood interacts with an early modern unchauvinistic culture of

\footnotetext{
17 And also the Dutch, but interestingly not the English or the Venetians (Chew 1933:283-289).

${ }^{18}$ The Reverend James Granger, in his Biographical History of England, writes that Anthony Sherley died in Spain in the 1630 .
} 
foreign relations (Parr 1995:20), and these suggest a specific political form through which various apparently opposed identities (Catholic or Persian, honourable or infamous) are constructed. In the words of Alison Games, like true "cosmopolitans" the Sherley brothers (and very notably Sir Robert and Sir Anthony), to a degree

demonstrated their interest in and sympathy for foreign mores, worked with and for foreigners, sometimes immersed themselves in foreign worlds, and gradually dislodged themselves from unthinking attachments to a single nation. (2007:25).

But the early modern travel trope, which in drama depicted a movement from departure (including exile), to the experience abroad, and concluded with the return home, is here disrupted by the impossibility of returning: Robert died in Persia, probably after having realized that he was no longer an Englishman; and Anthony remained an exile all his life. ${ }^{19}$ However, Anthony's departure and life-long estrangement from England were as much the consequence of circumstances (as he repeatedly tried to convince Cecil) as his own will, as many of his activities, notably his relatively unknown service for the Spanish crown in 1588, or his Persian adventure, seem to prove.

Narratives by and about the Sherleys are cultural, semiotic and material artefacts, produced in an ideological periphery (England's others, either Catholic or Muslim), and involve a diversity of boundaries (or "frontiers") crossed and of foreign customs confronted with national ones. This engages with Yuri Lotman's notion of the "Other:"

Since the boundary is a necessary part of the semiosphere and there can be no "us" if there is no "them," culture creates not only its own type of internal organization but also its own type of external "disorganization." In this sense we can say that the "barbarian" is created by civilization and needs it as much as it needs him. (2001:142)

It is hard to say who exactly were Anthony Sherley's "barbarians," as Persians, Turks, Spaniards or Englishmen were at turns, and somewhat contradictorily reproduced (or "created") as friends and

\footnotetext{
${ }^{19}$ Thomas, who peacefully died in the Isle of Wight in 1625 (the only brother to return to England), did not recover the family estate at Wiston, and spent some months in prison (Ross 1933:286-287).
} 
foes, civilized and wild. The "real" narrative of the Sherleys, therefore, does not exist, and it is as contradictory and irretrievable as the "Sherley myth." Texts have memory, and this might be defined as "the sum of the contexts in which a given text acquires interpretation" (Lotman 2001:19). In this essay I have tried to recover part of the memory of the previous contexts of these various texts, since the "culture of preceding ages inevitably comes down to us in fragments" (19), although I realize that the "memorable actes [...] [and] noble deedes" (Nixon 1607:B) of the three brothers will remain, to a large extent, a mosaic (a palimpsest) of disconnected fragments. And what this density of narratives tells us is precisely that, in more than one way, the Sherleys eventually become in these texts as alienated as the "others" they were trying to know and, ultimately, exploit for their own ends. Like these "others" (and like their own patron the Earl of Essex) their textual construction inevitably illustrates the extent to which they had become as difficult to reduce to a single narrative as the "spirits" Nixon refers to in his pamphlet (1607:B). Although not due to the fact that they had been "unkindly used by us [...] of the English Nation," Nixon was unknowingly right when he concluded that the three Sherley brothers had eventually become "strangers here at home" (1607:B2).

\section{References $^{20}$}

Andrea, Bernadette 2008. Women and Islam in Early Modern English Literature. Cambridge: Cambridge University Press.

Anon. 1933 (1600). "A True Report of Sir Anthony Sherley's Journey." Ed.

E.D. Ross. Sir Anthony Sherley and his Persian Adventure. London: The Broadway Travellers: $91-97$.

Bak, Greg 1996. "Different Differences: Locating Moorishness in Early Modern English Culture." Dalhousie Review 76/2: 197-216.

Brown, H.F. ed. 1900. Calendar of State Papers. Venetian 1603-07. London.

Burton, Jonathan 2005. Traffic and Turning. Islam and English Drama, 15791624. Newark: University of Delaware Press.

${ }^{20}$ Short Title Catalogue (STC) references are to the second edition (Pollard and Redgrave 1976-1991). All primary sources in English have been consulted at the Folger Shakespeare Library (Washington DC, US), and those in Spanish at the Biblioteca Nacional de España in Madrid. 
2009. "The Shah's Two Ambassadors: The Travels of the Three English Brothers and the Global Early Modern." Eds. B. Charry and G. Shahani. Emissaries in Early Modern Literature and Culture. Abingdon: Ashgate: 2340.

Cartwright, John 1611. The Preachers Travels. London. [STC 4705].

Ch[ambers], R[obert] 1609. A true historicall discourse of Muley Hamets rising to the three kingdoms of Moruecos, Fes, and Sus. London. [STC 430o].

Chew, Samuel C. 1937. The Crescent and the Rose. Islam and England during the Renaissance. New York: Oxford University Press.

Day, John, William Rowley, and George Wilkins 1607. The Travailes of the Three English Brothers. [STC 6417].

Dimmock, Mathew 2005. New Turkes. Dramatizing Islam and the Ottomans in Early Modem England. Aldershot: Ashgate.

Games, Alison 2007. "England Global Transition and the Cosmopolitans who made it Possible." Shakespeare Studies 35: 24-31.

Ghatta, Javad 2009. "'By Mortus Ally and our Persian Gods': Multiple Persian Identities in Tamburlaine and The Travels of the Three English Brothers." Early Theatre: A Journal Associated with the Records of Early English Drama [special issue of Early Modern English Drama and the Islamic World] 12/2: 235-249.

Gil, Luis 1985. "Sobre el trasfondo de la embajada del Shah Abbas I a los príncipes cristianos: Contrapunto de las Relaciones de Don Juan de Persia." Eclás 27/89: 347-377.

Granger, James 1769. Biographical History of England. London.

Green, M.A.E. 1870. Calendar of State Papers. Domestic Series. 1601-1603. London.

- 1871. Calendar of State Papers. Domestic Series. Addenda. 1566-1579. London.

Greenblatt, Stephen 1997. The Norton Shakespeare. New York: Norton.

Hakluyt, Richard 1903. The Principall Navigations, Voyages, Traffiques and Discoveries of the English Nation. 12 vols. Glasgow: J. MacLehose and sons.

Houston, Chloë 2009. "'Thou glorious kingdome, thou chiefe of Empires': Persia in Early Seventeenth-century Travel Literature." Studies in Travel Writing 13/2: 141-152.

James, Mervyn 1978. Society, Politics and Culture. Cambridge: Cambridge University Press.

Jones, Norman 1978. "The Adaptation of Tradition: The Image of the Turk in Protestant England." East European Quarterly 12/2: 161-175. 
(c) ederi 23 (2013)

Knolles, Richard 1610 (1603). The generall historie of the Turkes. London: Adam Islip. [STC 15052].

Lotman, Jüri M. 2001. Universe of the Mind. A Semiotic Theory of Culture. London \& New York: Tauris.

McJannet, Linda 2009. "The Translator as Emissary: Continental Works about the Ottomans in England." Eds. B. Charry and G. Shahani. Emissaries in Early Modern Literature and Culture. Abingdon: Ashgate: 147166.

Manwaring, George 1933 (ca. 1601). "A True Discourse of Sir Anthony Sherley's Travel into Persia." Ed. E.D. Ross. Sir Anthony Sherley and his Persian Adventure. London: The Broadway Travellers: 175-226.

Masood, Hafiz A. 2012. "From Cyrus to Abbas: Staging Persia in Early Modern England." Doctoral thesis. University of Sussex.

Matar, Nabil 1998. Islam in Britain. Cambridge: Cambridge University Press.

Menocal, María Rosa 2002. The Ornament of the World. How Muslims, Jews, and Christians Created a Culture of Tolerance in Medieval Spain. New York \& Boston: Little Brown.

Middleton, Thomas 1609. Sir Robert Shirley. London. [STC 17894]

Newton, Thomas 1575. A notable history of the saracens. London. [STC 6129]

Nixon, Anthony 1607. The Three English Brothers. London. [STC 18592].

Parr, Anthony 1995. "Introduction." Ed. A. Parr. Three Renaissance Travel Plays. Manchester \& New York: Manchester University Press: 1-54.

- 1996. "Foreign Relations in Jacobean England: The Sherley Brothers and the Voyage of Persia." Eds. J.P. Maquerlot and M. Willems. Travel $\mathcal{E}$ Drama in Shakespeare's Time. Cambridge: Cambridge University Press: 1431.

Parry, William 1933 (1601). "A New and Large Discourse of the Travels of Sir Anthony Sherley, Knight." Ed. E.D. Ross. Sir Anthony Sherley and his Persian Adventure. London: The Broadway Travellers: 98-136.

Persia, Don Juan de 1946 (1604). Relaçiones de don Juan de Persia. Ed. N. Alonso. Madrid: Ultra.

Persia, Don Juan de (Uruch Beg) 1929 (1604). Don Juan de Persia. A Shi'ah Catholic. Ed. E.D. Ross and E. Power. Trans. G. Le Strange. London: Harper (The Broadway Travellers).

Pinçon, Abel 1651 (1605). Relation d'un voyage de Perse. Paris.

Pollard, Alfred W. and Gilbert R. Redgrave eds. 1976-1991 A short-title catalogue of books printed in England, Scotland, $\mathcal{E}$ Ireland and of English books printed abroad, 1475-1640. London: Bibliographical Society. $2^{\text {nd }}$ edition. 
Publicover, Laurence 2010. "Strangers at home: the Sherley brothers and dramatic romance." Renaissance Studies 24/5: 694-709.

Purchas, Samuel 1905 (1625). Purchas His Pilgrimes. Vol. 1. Glasgow: J. Maclehose.

Ross, E. Dennison 1933. Anthony Sherley. His Persian Adventure. London: Routledge.

Sainsbury, W. N. Esq. ed. 1964. Calendar of State Papers. Colonial Series. 15131616. Public Record Office. Vaduz: Kraus.

Sha'ban, Fuad 1965. "The Mohammedan World in English Literature, ca. 1580-1642. Illustrated by a Text of The Travailes of the Three English Brothers." Doctoral thesis, Duke University.

Schleck, Julia 2011. Telling True Tales of Islamic Lands. Selinsgrove, PA: Susquehanna University Press.

Shand, G.B. 1983. "Source and Intent in Middleton's Sir Robert Sherley." Renaissance and Reformation 19: 257-264.

Sherley, Anthony 1613. Sir Anthony Sherley his relation of his travels into Persia. London. [STC 22424]

— [Xerly, Conde Antonio] 1622. Pesso político de todo el mundo. Madrid.

Sherley, Thomas 1936 (ca. 1607-08). Discours of the Turkes. Ed. E. Denison Ross. Camden Third Series. London: Offices of the Royal Historical Society.

Shirley, Evelyn P. 1848. The Sherley Brothers. Chiswick.

Singh, Jyotsna G. 2009. A Companion to the Global Renaissance. English Literature and Culture in the Era of Expansion. Malden, MA and Oxford: Wiley-Blackwell.

How to cite this article:

López-Peláez Casellas, Jesús. "Strangers at home: The Textual Construction of the Sherley Brothers." SEDERI 23 (2013): 33-56.

Author's contact: jlopez@ujaen.es

Submission: 13/02/2013 - Acceptance: 10/04/2013 


\title{
From Messina to Delhi: Much Ado about Staging Global Shakespeares in Olympic Times
}

\author{
Sofía Muñoz Valdivieso \\ Universidad de Málaga
}

\begin{abstract}
The present article discusses one of the contributions of the Royal Shakespeare Company to the World Shakespeare Festival, a celebration of the Bard as the world's playwright that took place in the UK in 2012 as part of the so-called Cultural Olympiad. Iqbal Khan directed for the RSC an all-Indian production of the comedy Much Ado about Nothing that transposed the actions from early modern Messina to contemporary Delhi and presented its story of love, merry war of wits and patriarchal domination in a colourful setting that recreated a world of tradition and modernity. Received with mixed reviews that in general applauded the vibrant relocation while criticising some directorial choices, this 2012 Much Ado about Nothing in modern-day Delhi raises a number of questions about cultural ownership and Shakespeare's international performance - issues that are particularly relevant if we see the play in relation to other productions of the World Shakespeare Festival in this Olympic year but also in the context of the increasing internationalization of Shakespeare's cultural capital in contemporary times.

KEYWORDS: Indian Shakespeare, Much Ado about Nothing, performance studies, Royal Shakespeare Company, worldwide Shakespeare.
\end{abstract}

Research for this paper was funded by the Andalusian Regional Government (Proyectos de Excelencia de la Junta de Andalucía): Research Project Po7-HUM-02507.

(5) ederi 23 (2013: 57-78) 
During the 2012 Summer Olympics London became the focus of international sport audiences, the prized location for international visitors and the object of the global gaze through the mass media. A large number of cultural activities took place in the UK in the socalled London 2012 Cultural Olympiad that had started in 2008, with programmes and projects inspired by the London Olympics. The culmination of the Cultural Olympiad was the London 2012 Festival which involved more than 25,000 national and international artists in events throughout the country. An important part of it was the World Shakespeare Festival produced by the Royal Shakespeare Company in collaboration with leading UK and international arts organisations and described by its organisers as a celebration of Shakespeare as the world's playwright (Mackenzie 2012). The present article focuses on one of the contributions of the Royal Shakespeare Company to the World Shakespeare Festival, an allIndian production of the comedy Much Ado about Nothing that transposes the actions from early modern Messina to contemporary Delhi and presents its story of love, merry war of wits and patriarchal domination in a colourful setting that can bring to mind Bollywood cinema. Directed by Pakistani-British director Iqbal Khan for the Royal Shakespeare Company and received with mixed reviews that in general applauded the vibrant relocation while criticising some directorial choices, this 2012 Much Ado about Nothing in modern-day Delhi raises a number of questions about cultural ownership and Shakespeare's international performance - issues that are particularly relevant if we see the play in relation to other productions of the World Shakespeare Festival in this Olympic year but also in the context of the increasing internationalization of Shakespeare's cultural capital in contemporary times.

The World Shakespeare Festival ran between April and November 2012. The Royal Shakespeare Company's assessment of the Festival on its website right after its closing stated that it had reached 1.5 million people and was therefore "the biggest celebration of Shakespeare ever staged" ("RSC: Updates and News"). ${ }^{1}$ A very

\footnotetext{
${ }^{1}$ The website summarizes the events of the World Shakespeare Festival in the following terms: "More than 10,000 professional and amateur artists and theatre makers from around the world have taken part in 69 full-scale productions, 7 exhibitions, 6 film screenings, 5 scratch performances, more than 260 amateur shows in Open Stages, new digital commissions on myShakespeare <url: my shakespeare.worldshakespearefestival.org.uk $>, 15$ commissioned short films on The
} 
visible part of the festival in London was Globe to Globe, a major international programme produced by Shakespeare's Globe which involved the performance of all of Shakespeare's plays by international companies in different languages in the course of six weeks at the Globe Theatre - as the promotional material stated, an unprecedented programme of multilingual Shakespeare productions that offered 37 plays in 37 languages. Unlike the Globe to Globe plays, the RSC productions for the World Shakespeare Festival were in English (with the exception of Romeo and Juliet in Baghdad, in Arabic, and a circus approach to the histories, Two Roses for Richard III, in Portuguese). Iqbal Khan's RSC Much Ado about Nothing was developed with an all British cast (crucially, an all British-Asian cast), was fully in English (with minor additions in Indian languages) and showed the utmost respect for the plot and language of Shakespeare's text. Originally staged in the summer of 2012 at the Courtyard Theatre in Stratford, it transferred to the London West End as part of RSC London season in mid-September for five more weeks.

This Indian Much Ado must be seen in relation to other Shakespeare plays performed by the RSC in the World Shakespeare Festival, such as Twelfth Night, The Tempest and The Comedy of Errors (the first two directed by David Farr and the third by Amir Nizar Zuabi, artistic director of the National Theatre of Palestine). The three plays were performed by the same cast and were conceived by David Farr as the shipwreck trilogy, in which "people arrive in places unexpectedly and face a huge challenge and culture shock" ("RSC 'What country'"). He chose them as "the right plays for the year of the London Olympics" since they explore "the recurrent obsessions of Shakespeare with migration, exile and the discovery of yourself through others" ("RSC 'What country"'). In fact, as was openly stated by the company itself, "[a]ll productions in the RSC repertoire during the Festival explore other cultures through the lens of Shakespeare's plays" ("RSC Much Ado"). This is the first context for the analysis of the RSC 2012 all-Indian Much Ado about Nothing: in an Olympic year when the World Shakespeare Festival is bringing to the UK local readings of his plays by foreign companies in different

Space <url: <thespace.org/items/soooogja> (alongside Globe to Globe's 36 filmed performances), 2 digital broadcasts, an online education collaboration with the BBC, and an international education conference" ("RSC: Updates and News"). 
languages, the iconic British theatre company is ready to present Shakespeare through a culture that is foreign, and yet not quite foreign, and to transport the play to a land that is distant, and yet close, because it may be the imaginary homeland of many of the $4 \%$ of British population who have family origins in the Indian subcontinent.

Iqbal Khan's Much Ado in Delhi is not the first RSC production of this comedy to be set in India, but the company's use of the Indian milieu and characters is very different from John Barton's 1976 version, in which the director transferred the action to a garrison town in the Raj at the end of the nineteenth century, with the highranking characters all English and the watch members all Indian (at the time, white actors in blackface). One of the keys to the success of Barton's version was apparently "the hilarious antics of the Watch, played as an Indian Dad's Army, complete with funny 'babu' accents and Indian body-language ill adapted to the conventions of the British Army" (Gay 1994:161), a concept that nevertheless some members of the audience found "offensive - racist and patronising" (Gay 1994:161). ${ }^{2}$ John Barton's approach to the social gulf in Messina society in such blatant racial terms would cause general discomfort in contemporary audiences and undermine the overall value of the production.

The second context for the all-Indian RSC production of Much Ado about Nothing in 2012 is very succinctly presented in the official website of the Globe to Globe programme, a map of the world with hyperlinks on all five continents for all the international productions that were presented at the Globe. This cartography of the world through Shakespeare conveys in visual shorthand the sense that the work of the Bard is, like the Olympic Games, a worldwide affair: not only was he a truly global author that in his own time recreated the entire world in the playhouse (a key idea in the 2012 British Museum exhibition, "William Shakespeare: Staging the World"), but his work is the key gift of Britain to world culture which can still in its many afterlives project Britain onto the world and bring the world to

\footnotetext{
${ }^{2}$ Critic Penny Gay herself had mixed feelings about this choice for the watch: although she perceived the racism in the conception, she found that she was "smiling at the comic performance of John Woodvine's Dogberry, which certainly put life into those old jokes which critics almost unceasingly complain are never funny enough" (Gay 1994:161-162).
} 
Britain. The World Shakespeare Festival reflects a sort of paradox in contemporary Shakespearean performance and scholarship: on the one hand, as stated in the leaflet for the British Museum exhibition, "William Shakespeare is Britain's greatest cultural contribution to the world" ("Shakespeare: Staging the World") - and the strong presence of his plays in the official cultural programme of the year is the Olympic endorsement of that; on the other hand, this great cultural icon appears to belong to Britain in increasingly tenuous ways, due to the steady development in the last decade of what initially, in Dennis Kennedy's pioneer volume of 1993 were called "foreign" Shakespeares and alternatively, and ever more so, "worldwide," "local" or "global" Shakespeares. ${ }^{3}$ As Kennedy and Yong indicate in their introduction to a recent volume on Shakespearean performance in Asia,

Much has happened on planet Shakespeare since 1990. For our purposes the most important has been a notable increase in Shakespeare performance in surroundings alien to the traditions of the main English-speaking nations, some of which has been exported to the West, prompting corresponding expansion in the international critical attention those productions have received in the popular press and in the academy. (Kennedy and Yong 2010:1)

Recent years have indeed witnessed a growing interest in Shakespearean productions and afterlives outside Britain and the English-speaking world, particularly in Asia, with the proliferation of studies of non-English Shakespeares in specific areas of the world, such as Murray J. Levith's Shakespeare in China (2004), Poonam Trivedi and Dennis Bartholomeusz's India's Shakespeare: Translation, Interpretation, and Performance (2005), Alexander C. Y. Huang's Chinese Shakespeare: Two Centuries of Cultural Exchange (2009), Dennis Kennedy and Yong Li Lan's Shakespeare in Asia: Contemporary Performance (2010) and Poonam Trivedi and Minami Ryuta's Replaying Shakespeare in Asia (2010). Volumes such as these attest to the "explosion of critical interest in the way that Shakespeare has been

\footnotetext{
3 "World-wide" is used by Kennedy himself in his contribution to the 2001 Cambridge Companion to Shakespeare and Sonia Massai in World-Wide Shakespeares: Local Appropriations in Film and Performance (2005); "local" is used in volumes such as Martin Orkin's Local Shakespeares: Proximations and Power (2005); "global" is used for instance in Craig Dionne and Parmita Kapadia's Native Shakespeares: Indigenous Appropriations on a Global Stage (2008).
} 
made to accommodate local cultures across the globe" (Dionne and Kapadia 2008:5), a tendency that is occasionally questioned by a number of scholars, both from the great centres of learning of the West and from non-Western locations. Some like Ania Loomba show an awareness of the market forces at work in the internationalization of the cultural capital of Shakespeare, as when she states in reference to some of these worldwide performances that "in our globalized world, a 'hybrid' Shakespeare - one who allows a fusion, a truly postmodern montage, of once-colonized and once-colonizing cultures, the Metropole and the Global South, center and periphery has become a highly marketable commodity on stages in different locales" (Loomba 2008:209). ${ }^{4}$ A more poignant case at hand is the two-decade long critical take of Rustom Bharucha on the appropriation of Eastern performance elements by major directors in the West (one focus of his 1993 volume Theatre and the World) and his discomfort with some of the interpretations of "foreign" Shakespeares by Western scholars - and even more so, his overall questioning of the whole enterprise in the occasional uncharitable reading of it as stemming from strictly pragmatic concerns: "[i]s the preoccupation with Shakespeare in other cultures not simply a means of extending the information retrieval on an arguably burnedout Bard?" (Bharucha 2004:4).

On the whole, however, congratulatory readings of this new expansion of Shakespeare throughout the world are predominant, with some scholars even seeing in these new productions reasons to celebrate a greater balance between the first world and the emerging world - at least in terms of the cultural capital represented by Shakespearean performance. As Poonam Trivedi and Minami Ryuta state in their introduction to Re-playing Shakesperare in Asia,

[t]he recognition, circulation, and approbation of Asian versions of Shakespeare in the last few decades mark a shift in intellectual property relations. A side benefit of globalization has been the expansion of the areas of reckoning: "other Shakespeares" can now cohabit the same playing space as the metropolitan. (Trivedi and Ryuta 2010:2)

4 Even the highly celebratory Kennedy and Yong recognize that non-Western Shakespearean productions play "on a double marketability for their international audiences: the name brand of Shakespeare and the performance of the exotic" (2010:12). 
This attention to Shakespeare's work in its non-English incarnations can be connected to a more general tendency in Renaissance Studies in recent years to conceive early modern English culture in its relation to the rest of the world. As Joytsna Singh indicates in The Companion to the Global Renaissance (2009), "recent globally oriented scholarship of the past decade has led the way in creating a more expansive, shifting Renaissance world-picture" (Singh 2009:5), and scholarship in recent years has traced the origins of present-day globalization to the cross-cultural interactions of Renaissance England with Europe and with the Americas, Africa and the East as it explores "the impact of global economic, cultural, religious and political developments on English society and culture during the sixteenth and seventeenth centuries" (Singh 2009:5). ${ }^{5}$

In keeping thus with the international spirit of an Olympic year and with the predominant contemporary perception that Shakespeare is indeed a global author, in 2012 the World Shakespeare Festival gathered as we have seen many productions of what only a few years ago used to be called foreign Shakespeares but are increasingly designated with terms such as local, worldwide or global. The Shakespearean festival of 2012 is not only appropriate for an Olympic year but the result of the awareness that innovative Shakespearean performances may indeed come as much from outside Britain as from within - and that bringing them onto the British stages, particularly the Southbank Globe, is a way of grounding them in the Bard's soil: performing them in the recreated Renaissance playhouse re-routes (and re-roots) them to their place of origin. Iqbal Khan's Indian Much Ado with an all British(-Asian) cast is a different take on worldwide Shakespeares in this Olympic year. Like the African RSC production of Julius Caesar - also with an all (black) British cast - that it followed upon at Stratford, this Indian

\footnotetext{
${ }^{5}$ Another strand in this weaving of a global Renaissance concept comes from the work of scholars that are opening up the very idea of Renaissance England even in terms of population, with significant efforts to include in the image of the country the erased presence of Africans at the time by so-called empirical race studies - represented for instance by Imtiaz Habib's Black Lives in the English Archives, 1500-1677 (2008), a book that "boldly reconfigures the archive of sixteenth- and seventeenth-century English history by uncovering an actual black population, previously considered tiny and insignificant" (Singh and Shahani 2010:136), as it finds "hidden in the vast archives of parish churches within London and without, all through the Tudor and Stuart reigns [...] voluminous cryptic citations of 'nigro', 'neger', 'neyger', 'blackamoor', 'moor', 'barbaree'" (Habib 2008:2).
} 
version of Much Ado is part of an attempt to reclaim the Bard for sections of Britain's population that may feel excluded from Shakespearean performance, a response to the sense that the cultural capital of Shakespeare, so very much circulating on the worldwide stages of other languages and cultures, belongs to all British people, including those whose family roots take them to other continents. The RSC Much Ado shows how in their conceptions of Shakespeare's plays directors try "to respond to the changing social climate" (Wynne-Davies 2001:5), the production in this case attempting both to reflect and to change social perceptions of Shakespearean performance. For most of the actors, including protagonist Meera Syal, this play was their debut season with the RSC and the director of the company Michael Boyd openly expressed his wish to appeal to a more varied theatre audience in Stratford: "We are a very white organisation [...]. Only $2 \%$ of our audience at Stratford is Asian, black or from an ethnic minority [...]. Some Asian families come [to Stratford] at weekends to mess about in boats on the river here but they do not come to the theatre. We need to change that" (Boyd in Brooks 2012:15).

This attempt to make Shakespeare relevant to Asian communities in Britain is in line with Michael Boyd's decade-long effort to open up the Royal Shakespeare Company to international and multicultural performance - the 2012 World Shakespeare Festival was the last major event he organised as its artistic director. Boyd had been responsible for the 2006 year-long Complete Works of Shakespeare Festival which involved thirty companies, nineteen of which were international. One of the great successes of the festival was a pan-Indian version of A Midsummer Night's Dream directed by Tim Supple that gathered actors from across the Indian subcontinent and presented the play in English and seven Indian languages. Before stepping down from the RSC Michael Boyd left in place for the 2013 spring season Tanika Gupta's The Empress, a play about Queen Victoria's relationship with one of her Indian servants and the Indian presence in England at the time. Iqbal Khan's Much Ado about Nothing is one more example of Michael Boyd's role in bringing together British and Indian culture.

Iqbal Khan's all-Indian production was conceived and promoted around the figure of well-known British comedienne, scriptwriter and novelist Meera Syal as Beatrice, the female 
protagonist of the secondary plot of the play, which is indeed as powerful, or more so, than the story of Claudio and Hero, its nominal main plot - most critics "literally or figuratively put the term in quotation marks and are quick to point out that Beatrice and Benedick overshadow this 'plot', however 'main' it is" (Neely 1985:56). For generations audiences have attended performances of the play to witness the merry verbal wars between these two characters, who can be seen in their witty verbal exchanges as forerunners of the verbal fencing of Restoration comedy and the sparkling dialogues of 1930s Hollywood screwball comedy - with Benedick and Beatrice's battle of the wits in this particular production as "reminiscent of the nok-jhok or playful banter that is the stuff of Bollywood romance" (Shahani 2012). Some reviewers perceived connections of Khan's play with the productions of the massively popular Indian film industry, and references to Bollywood were a way to describe the visual and aural impact of the vibrant setting and the group dance numbers - which in fact the director, in a restrained use of the Bollywood spirit, introduced strictly where the original play calls for music and dance, at the masquerade in 2.1 and in the final celebration in 5.4. The Daily Mail description of the play as a "Bollywood extravaganza" (also used in some RSC publicity posters) went too far in the analogy, even though perceptions of certain parallelisms with Indian films were inevitable among reviewers, from positive assessments of Bollywood vibes to evaluations of the play as "vigourously populist, [...] frenetic and overspiced" (Billington 2012).

Meera Syal appears on the programme cover and publicity posters presiding Titania-like on a colourful huge globe against a night background with a cascading net of lights: radiant yet mischievous, her demeanour as she sits on a saffron, pink and white globe (a huge incarnation of the globe-like logo of the World Shakespeare Festival) grants her a relaxed authority that puts her at the centre of the play. Casting Meera Syal as Beatrice to head the all British-Asian cast and making her the focus of some of the publicity for the play is a strategic move on the part of the RSC to bring minority communities closer to Shakespeare with a performance that links the Bard and the Indian subcontinent. British audiences may not be aware of the complex history of Shakespearean performance in India or of the role of Shakespeare's texts in implementing the 
colonial system of education. ${ }^{6}$ Most of them will be familiar, however, with Meera Syal as a comic actress, the protagonist of $\mathrm{BBC} 2$ sitcoms Good Gracious Me and The Kumars at No 42 - some may even know that she is a scriptwriter and the author of two novels about British-Asian experience, Anita and Me (1996) and Life isn't all $\mathrm{Ha} \mathrm{Ha} \mathrm{Hi} \mathrm{Hi} \mathrm{(1999).} \mathrm{Director} \mathrm{Iqbal} \mathrm{Khan} \mathrm{was} \mathrm{concerned} \mathrm{that} \mathrm{among}$ some British minorities "Shakespeare still represents a colonial power" (Khan in Brooks 2012:15) and casting a popular star like Syal was his first step towards reclaiming ownership of the Bard for British-Asian audiences.

Meera Syal argues for the transposition of Much Ado about Nothing to India in the following terms:

[T] he fact that our production sets it in India makes so much sense. At the centre of the play is something that is almost an honour killing. Couple that with the fact that the play shows two contrasting kinds of marriages, one that is a love marriage and one that is much closer to an arranged marriage, and you don't have to reach to make it relevant. ("Moments of Revelation") ${ }^{7}$

In fact, the Royal Shakespeare Company chose to transpose the play to present-day Delhi because it appeared as a location in which to find "the contemporary world existing alongside traditional values" ("RSC Much Ado"). Distancing the location and/or the time of the play from that of the audience has been the rule of twentieth and twenty-first century productions of the play, from John Gielgud's celebrated Stratford performances of the 1940s and 1950s, which retained a Renaissance atmosphere, to the 2011 West End success which placed it in Gibraltar in the eighties after the Falklands War or the Globe production of the same year which blended early Modern Messina and Morocco, from the psychedelic reds and oranges in an empty box of the Tudor production directed by Trevor Nunn for the RSC in 1968 to the early Victorian conservatory, the Sicily of

\footnotetext{
${ }^{6}$ For a succinct history of Shakespearean reception in India see Trivedi (2011).

7 This particular play has special resonance for her: "Rehearsing that wedding scene was shocking, and it contained echoes of other things that I'm involved with. I'm the patron of Newham Asian Women's Project and we fund refugees for women escaping violent marriages. These are real" (“Moments of Revelation").
} 
Mussolini, or the Cuba of 1953 in the RSC versions by Ronald Eyre in 1971, Gregory Doran in 2002 and Marianne Elliott in 2006. ${ }^{8}$

"Comparisons are odorous" says the watch leader Dogberry in 3.5.15, ${ }^{9}$ but Khan's play was indeed staged at a time when a cluster of highly visible productions of $\mathrm{Much}$ Ado appeared on the London stages: the 2012 RSC Much Ado trailed behind Jousie Rourke's West End production of 2011 (with Doctor Who David Tennant as Benedick) and Jeremy Herrin's version at the Globe of the same year, as well as the French Globe to Globe version of 2012. (It also happened to be onstage right at the time of the premiere at the Toronto Film Festival in September 2012 of the extremely well received and then soon to be released black-and-white modern-dress adaptation of Much Ado About Nothing by popular film director Joss Whedon.) While these theatrical productions moved the actions to the close or distant past, Khan's version places it in the present and it attempts to recreate modern-day India as a land of contradictions in which the forces of modernity are at odds with long-entrenched patriarchal perceptions about women. This is an idea that is repeated in interviews with the director, actors, and other members of the ensemble, such as set designer Tom Piper, who describes the production as "akin to something like Monsoon Wedding, which will celebrate both traditional culture and assess the impact of modernity" (McLaughin 2012). Or Khan himself, who insists that when he thought "about the themes of the play - chastity and pure blood lines, the rituals of courtship, the arrangements of marriage" he realised that "all of those things are incredibly vital in India" (Iqbal 2012).

Unlike the Globe to Globe productions, Iqbal Khan's Much Ado is fully performed in English, with the exception of songs and a few interjections among the servants and occasionally when the masters address them. The ruling principle for Khan has been his utmost respect for Shakespeare's text, which is only altered minimally to adapt certain details to the Indian setting and keep up with the cultural transposition from early modern Messina to contemporary

\footnotetext{
${ }^{8}$ For the performance history of Much Ado, see Gay (1994), Cox (1997) and Bate and Rasmussen (2009). It can be argued that in the play Messina is in fact "any romantic place lived in by rich and relatively important people" (Everett 2001:60).

${ }^{9}$ All subsequent references to Much Ado about Nothing are to Zitner's edition (1994).
} 
Delhi. Thus, the friar who develops the scheme of Hero's death in the play becomes a pandit who celebrates the wedding in Leonato's house, since in India "often the religious minister comes to the house and will marry the couple at home" ("RSC Much Ado"); the references to church are replaced by "temple;" and where Italy is mentioned usually India is inserted (there is some mixing in this, with Benedick described as "the properest man in India" instead of "in Italy" in 5.1.169 but Dogberry referring to himself as "pretty a piece of flesh as any is in Messina" in 4.2.81-82). Correspondingly, the contemporary Delhi setting means that traditional Indian clothes are mixed with contemporary Western-style jeans and shirts. Beatrice significantly first appears on stage reading from a tablet in a power suit and high heels that may suggest a life outside the domestic sphere as a successful business woman. This relocation of the actions to modern-day Delhi, with its mingling of modernity and traditional values, allows for interesting explorations of certain areas of the play while it can be problematic in others.

The transposition of this particular Shakespearean comedy to contemporary Indian society appears to make sense on a number of levels: reviews frequently highlight the suitability of the Indian setting as "a land of tradition and transition, vigour and swagger and intense awareness of rank" (Purves 2012:64) and stress the appropriateness of "communality and hierarchical structuring of life in India that map effectively on to similar structuring in Elizabethan England" (Brennan 2012). It may be excessive to claim, as Jyotsna Singh does, that in this performance "early modern Messina is transposed to contemporary Delhi in a way that richly illuminates and transforms the idioms of both worlds" (Singh 2012), but it is true that certain aspects of the plot may fit in together more easily if the actions are moved to India. However, this transposition of setting and time also transfers to contemporary Indian society the problematic aspects of the play as a romantic comedy, the "tensions, contrarieties and dissonances" (Cox 1997:67) of the Claudio-Hero plot and the discomfort that contemporary audiences may feel at the fissures of the final festivities, which celebrate multiple weddings the day after an innocent bride has been humiliated at the altar with false accusations of unfaithfulness. All in all, from a contemporary point of view the patriarchal power lines that propel the actions in the play are hard to accept: they encroach upon society's interactions 
so much that a female member of the community has to pretend to die so that she can be reborn chaste and pure.

Claudio's extreme inexperience in matters of love is sometimes emphasized by critics as the basis of his cruel naivety as "a young man uncertain of his judgement of women" (Ornstein 1986:123) and directors frequently choose to downplay his callous behaviour by making him appear very young and gullible, and his repentance after the revelation of the truth powerfully remorseful. That was Kenneth Branagh's decision in his 1993 film version of the play, for instance, through the use of close-ups of Claudio's suffering face and an extended sequence for the mourning scene in 5.3., and also Jousie Rourke's strategy in her 2011 West End play, by showing his attempted suicide at Hero's tomb. Some productions do visualize the supposed treason of Hero to reinforce for the audience the evidence presented to Claudio and Don Pedro (also the case in Branagh's and Rourke's productions). Khan's Claudio does not appear particularly naïve or young, nor is he manipulated into "seeing" Hero's unfaithfulness - this incident is, as in Shakespeare's original text, simply narrated by Borachio to Conrad the night they are caught by the motley city watch. Khan's effort to soften his cruelty is only channeled through the visually powerful mourning scene in 5.3.

The problem of Much Ado as a comedy is that the festive spirit is tainted by the re-assimilation of characters into a restored happy society that may be perceived to be deficient. The stage history of the play shows that it has "moved around geographically partly at least as a response to [...] the need to find a cultural ambience which might explain if not excuse Claudio's callous treatment of Hero and Leonato's response to her slander" (Bate and Rasmussen 2009:121). And thus one major success of this production, the powerfully enacted bashing-scene in which Hero is rejected, is a great asset that can become a problematic area, to the extent that Khan's production may appear to be recasting without apparent criticism or ironic distance the ugly side of the still strongly patriarchal society of India. When asked how this situation sits with the country's attempts to rebrand itself as an aspiring superpower, the director's response was that "Delhi is about as Elizabethan a place as you could find in the modern-day world" (Iqbal 2012). The emphasis on the final celebration of 5.4, a Bollywood-like dance sequence with no dark strains to it, carries with it the danger of an implied acquiescence 
with the previous situation - a lack of criticism that is easier to accept in productions that present the patriarchal structures as part of a past time in a distant place. ${ }^{10}$

The set design by Tom Piper was overall one of the main successes of the production, and its one significant change in the mourning scene in 5.3 its main attempt to temper Claudio's cruel behaviour by powerfully showing his suffering and his repentance. Tom Piper recreated in his set the domestic environment of a northern Indian haveli and courtyard, with a running upper gallery and several doors for entrances and exits like the early modern stage, a decorated rail staircase on the left that led to the gallery and a huge tree with tangled wires and ropes upstage on the right which embodied the orchard that Benedick mentions as his location in 2.3. This tree which visually captured something of the disarray of the Indian electric power supply system was to be the focal point of several moments in the play, both as the site of part of the gulling scenes for both Benedick (on top of it as he eavesdropped) and Beatrice (on its bench while she herself overheard), and also as the crucial place for them to reveal their love to each other as they cradled together on its large swing after Hero's rejection. ${ }^{11}$

The set remained for the most part static and changed radically only once, for the mourning scene at Hero's tomb in 5.3, when the front walls of the courtyard were moved to reveal, in very dark light and with falling rain that drenched the umbrella-carrying mourners, the smoking funeral pyre of Hero. Tom Piper's setting played a crucial role in this remembrance ceremony, with the characters under the rain as they faced away from the audience into the distance so that a sense of communal grief was created that reinforced Claudio's presentation of the epitaph upon Hero's tomb

\footnotetext{
${ }^{10}$ Also contributing to the possible perception of an implicit acquiescence with the patriarchal structures is Khan's absolute respect for Shakespeare's text: he does not cut out any of the occasionally dropped passages that cast Claudio as particularly callous, such as his jovial teasing of Benedick right after the aborted wedding in 5.1.109-190.

${ }^{11}$ The original design for the thrust stage at the Courtyard Theatre in Stratford had to be adapted to the proscenium theatre in London and the closeness to the audience of the original venue was partly diminished. The foyer of the theatre in Stratford had also provided a space for the audiences' immersion in the sights, sounds and smells of Delhi that could not be reproduced in the West End. Overall, Tom Piper's set design in both venues was a visual feast.
} 
as he follows Leonato's injunction to "sing it to her bones" (5.1.279). This was an important moment of transition between the interrupted wedding and the closing festivities and Khan payd significant attention to it in order to show a powerful display of Claudio's penance at Hero's tomb - and so temper some of the anger his behaviour may have produced both in the Messina-Delhi family and in the Stratford-London audiences. Showing a repentant Claudio in any possible way helps audiences accept that there is "a change in Claudio sufficient to warrant his good fortune in the next scene, where Hero is restored to him" (Cook 1986:198), and the mourning scene in this production was a powerful attempt to counteract the effect of Hero's earlier humiliation at her wedding in 5.1.

The ravishing set created by Tom Piper for the marriage ceremony highlighted the force of the wedding scene, which in the play shows how a woman's chastity is (in Renaissance slang) the "no thing" about which much is done in the play: the rejection of Hero at the altar, which Tom Piper turned into a mandap, reverberated in ways that could bring to mind the so-called honour crimes (a term in itself in need of revision) still carried out in a number of cultures. Claudio's public verbal bashing of Hero was amplified not so much by his performing it on a microphone but by the sumptuous and carefully crafted celebration of a happy union that it destroyed. Much of the strength of this moment in the production was visual, since Piper's reconstruction of the colourful setting of a big ceremonial wedding made the dashing of the participants' happy expectations all the more poignant. These were the elaborate preparations and ornate setting appropriate for a formal Punjabi wedding that may appear at odds with Leonato's request to the pandit to carry out "the plain form of marriage" (4.1.1-2), but indeed the text of the play itself suggests spectacular clothes in Margaret's previous description of Hero's sumptuous gown through a comparison with that of a Duchess (3.4.13-22). The mandap was constructed in saffron and pink decorations, with hangings from the ceiling that use the verticality of the stage, so that a link of the wedding celebration to the previous domestic life was established: these rich swaths of pink and saffron fabric were the visual counterpart of the gigantic white sheets hanging from the ceiling before the play's beginning, which were duly removed and folded by some of the house servants as they collected this massive laundry left to dry in the warm air. 
Khan's production actually excels in the development of the lower-ranking strands of the story, and here is where the director feels freer to include elements outside the text that may enliven the production. The underbelly of the big house is peopled by girl servants, cook, boy helpers and a number of characters from the lower levels of this India-like world who are shown to be the sustenance of its smooth working. Their moving in and out of the stage, whether it be repairing small appliances, folding the laundry or refreshing the ever-present drinks, shows a society in which servants may be invisible to their masters but certainly not to the audience. From the moment they stepped into the auditorium (and even before, when they entered the foyer at the Stratford venue), members of the audience encountered characters moving around in a domestic space that was vibrantly alive with the hustle and bustle of a big house with extended family, criss-crossing encounters and many chances for observing what others do-a good location for the "noting" at the centre of the play. Street noises blared through the theatre speakers as a reminder of the hot crowded streets outside the household and of chaos pulsing through the public spaces of the city. In this setting, the opening words of the production were granted to the underclass: Ursula, the only female in sari before more formal occasions - and actually unacknowledged as a woman in the programme since she was conflated with the watch member Verges - broke the fourth wall to interact with the arriving audience members while other servants moved around among the seats, and a highly likeable turbaned Sikh Dogberry in an appropriately malapropism-ridden speech made the pre-play "denouncement" that mobile phones and other electronic devices should be turned off.

The one-sentence role of the boy who in 2.3.5 tartly responds to Benedick's request that he bring him a book to the orchard was extended to the point that Anjana Vasan's maid became a comic presence through long passages of the play, repeatedly attempting for instance to take the requested book to Benedick as he overhears in the gulling scene, performing an informal dance to Balthasar's song in 2.3 and running in and out of the staging area before the beginning and after intermission, which in this production took place at the end of 3.2, with Don John planting the seed of suspicion in the minds of both bridegroom Claudio and his friend and mentor Don Pedro, so that the second part opened onto a stage that had 
been in part transformed into the mandap for the upcoming wedding. The importance of the watch in clearing the confusion of the upper ranks at the wedding was suggested by maintaining the mandap in the darkened background while the members of the watch gathered and got ready for duty and later while they began their job by falling sleep, so that the two very different worlds of night watch and wedding celebration were visually linked. The watch in this production captured what they are in the original play: a motley group of citizens that are engaged for that service but who really are more comfortable in their kitchens, shops and other regular places of work. Khan made them a key source of the play's humour but they were treated with respect as the agents of resolution, the lowerranking forces that brought to justice the evil-makers and opened the way for the restitution of Hero's honour. When their "betters" had been unable to see where truth and honesty lie, this homely crew became the real peace-keeping forces in the play - the counterpart to the upper-class military forces that have solved conflict elsewhere but bring conflict to the peaceful Messina-Delhi domestic environment.

Precisely the director's conception of the military world that impinges upon the domesticity of Messina is another problematic area in the production. The justification for them to appear as UN forces is presented in the programme, in Gintanjali Shahani's essay about Indian peace-keeping forces around the world:

With Khan's heroes comprising entirely of men from the Indian military, we have a postcolonial adaptation that is keenly aware of India's peacekeeping efforts and diplomatic aspirations in a global arena. Since the 1950 S [India] has participated in over 40 peacekeeping missions in four continents, with nearly 9000 personnel in operations worldwide. (Shahani 2012)

Despite Shahani's enthusiasm about the inclusion of this commonly overlooked aspect of Indian reality, the arrival of the military men in the uniform and blue berets of UN peace-keeping forces was not easy for audiences to grasp. Their coming did not powerfully convey the contrasting worlds of war and domestic life, "the gulf between the off-duty military, dreaming up ways to pass the time, and the civilian population" (Billington 2012); their entrance did not transmit the sense of a war ending, nor did Don Pedro's appearance project the image of a dignified superior who would therefore be in a 
position of authority to take command of the fictional world of the play.

These military uniforms were also used in another key moment of the play with equally mixed results. Khan's choice of resources for the masquerade in 2.1 in which Don Pedro woos Hero on behalf of Claudio played with cross-dressing: the women danced in military jackets, blue berets and dark sunglasses, while the men wore scarves over their heads as they pretended that they were women Antonio's elderly face is even covered with makeup. ${ }^{12}$ The director's intention was to reflect the fact that in many Indian celebrations, there are times "when men and women gather separately, with the ladies pretending to dance like the men and the men imitating the women to make their friends laugh" ("RSC Much Ado"). On the stage, however, this transformation of the characters was not easy to grasp, and the masquerade scene became a site of uncertainty, a celebration of sorts that is not fully understood. Khan's choice could be sensed as a momentary reversal of gender roles, with the women in charge of the conversation and the men coyly (and for the purpose of disguise) hiding behind their scarves as veils, so that the playful gender-crossing momentarily empowers the female members of the community - so briefly indeed that soon their inequality will burst into the tragedy of the defamed Hero unable to speak for herself. ${ }^{13}$ This brief upturning of the power structures is a carnival-like party that breaks the established order for a moment only to channel it back to its usual shape. And the fact remains that as in the original Shakespearean text Hero is mostly silent, her condition as a subjugated female a reality in the fictional world of the play that is in part veiled by the dazzling final celebrations of this Messina-Delhi society as it welcomes all its members (the evil Don John excepted)

\footnotetext{
${ }^{12}$ In this scene Benedick is the only man that is fully dressed as female in a sari that turns Paul Bhattacharje's lanky figure into quite a ridiculous visual enactment of Beatrice's injunction that he is Don Pedro's jester (2.1.137). His comic body as female is also used in the gulling scene, the latter part of which he spends as a covered elderly woman, cleaning Don Pedro's and Claudio's shoes as they speak apparently unaware of his presence.

${ }^{13}$ The production suggests that Don John is disturbed by his constraints as a homosexual and there are hints that he is attracted to Claudio. The source of his malcontent status which the early modern audiences could easily grasp as stemming from his being a bastard brother is thus turned into the cankerous care of a misfit who is sexually oppressed, so that his words "I cannot hide what I am. I must be sad when I have cause, and smile at no man's jests" (1.3.12-14) resonate differently.
} 
into a dance, a vibrant Bollywood moment of sheer enjoyment and communal harmony.

Khan's play was an attempt to produce Shakespeare massala that is spiced enough to appeal to most British (and possibly international) palates in its recreation on Stratford and London stages of a vision of contemporary Delhi that attempts to balance the exotic and the familiar to produce distance yet recognition, so that most spectators can relate to it in some way - even if those in the British audiences that trace family and emotional ties to the Indian subcontinent experience something like Salman Rushdie's "Indias of the mind" (Rushdie 1991:10), the sense that they are recreating in their imaginations a portrait of a homeland they may have never actually seen and experienced. Despite the problematic areas that have been discussed above, Khan's Much Ado about Nothing had the power to bring new audiences to Shakespeare. All the RSC productions during the World Shakespeare Festival explored other cultures through Shakespeare's plays, and as the company keeps opening up its work to the world, ${ }^{14}$ this first all-Asian production of a Shakespearean play was an attempt to reclaim the Bard for AsianBritish and other ethnic minorities in Britain as other than the foreign and colonizing agent of their ancestors. The director of the British Museum, which in 2012 hosted an exhibition entitled "Shakespeare: Staging the World", suggests that the professional theatre in Shakespeare's time was indeed "the first mass medium for the presentation of cultures of the world to a wide public [since] in Shakespeare's time the globe was brought to life on the bare platform of the Globe Theatre in Southwark" (MacGregor 2012:9). Iqbal Khan was the first Asian-British director to do a major Royal Shakespeare Company play - curiously enough, the same Shakespearean comedy that started their repertoire when the company was created in 1961. It would be an exaggeration to say that Iqbal Khan's production of Much Ado about Nothing was a radical reinvention of the play, but its Indian-inflected prose and poetry and Punjabi-clad festivities opened the Stratford and London stages of the RSC for a celebration of the Bard not only as the world's playwright but, crucially, as the playwright of all Britons: at a time

\footnotetext{
${ }^{14}$ In the autumn of 2012 it presented its first Chinese production, The Orphan of Zhao, the so-called Chinese Hamlet - with a major controversy over its not casting enough British-Asian actors.
} 
when global and worldwide Shakespeares are becoming the centre of scholars' and spectators' attention, producing this Delhi Shakespeare by an all British-Asian ensemble was yet another attempt to bring the Bard home.

\section{References}

Bate, Jonathan and Eric Rasmussen 2009. "Much Ado about Nothing in Performance: The RSC and Beyond." Eds. Jonathan Bate and Eric Rasmussen. Much Ado about Nothing. Basingstoke: Macmillan.

Bharucha, Rustom 1993. Theatre and the World: Performance and the Politics of Culture. London: Routledge.

— 2004. "Foreign Asia / Foreign Shakespeare: Dissenting Notes on New Asian Interculturality, Poscoloniality and Recolonization." Theatre Journal 56/ 1 (March): 1-28. [Rptd. in Kennedy and Yong (2010: 253-280)]

Billington, Michael 2012. "Much Ado about Nothing Review." Rev. of Much Ado about Nothing, dir. Iqbal Khan. The Guardian 2 August 2012 <url: http://www.guardian.co.uk/stage/2012/aug/o2/much-ado-aboutnothing-review>. Last accessed 15/07/2013.

Brennan, Clare 2012. "Much Ado about Nothing Review." Rev. of Much Ado about Nothing, dir. Iqbal Khan. The Observer 5 August 2012 <url: http://www.guardian.co.uk/stage/2012/aug/05/much-ado-aboutnothing-review $>$. Last accessed 15/07/2013.

British Museum 2012. Shakespeare: Staging the World. British Museum Exhibition Brochure, 19 July-25 November 2012.

Brooks, Richard 2012. "All the World's an Ethnic Stage." Rev. of Much Ado about Nothing, dir. Iqbal Khan. Sunday Times 15 August 2012: 15.

Cook, Carol 1986. "'The Sign and Semblance of her Honor': Reading Gender Difference in Much Ado about Nothing." PMLA 101: 186-202.

Cox, John F. 1997. "Introduction." Shakespeare in Production: Much Ado about Nothing. Cambridge: Cambridge University Press: 1-85.

Dionne, Craig and Parmita Kapadia eds. 2008. Native Shakespeares: Indigenous Appropriations on a Global Stage. Aldershot: Ashgate.

Everett, Barbara 2001. "Much Ado about Nothing: The Unsociable Comedy." Ed. Marion Wynne-Davies. Much Ado about Nothing and The Taming of the Shrew. Basingstoke and New York: Palgrave: 51-68.

Gay, Penny 1994. As She Likes It: Shakespeare's Unruly Women. London and New York: Routledge. 
Habib, Imtiaz 2008. Black Lives in the English Archives, 1500-1677. Burlington, VT: Ashgate.

Huang, Alexander C. Y. 2009. Chinese Shakespeare: Two Centuries of Cultural Exchange. New York: Columbia University Press.

Iqbal, Nosheen 2012. "Much Ado about Delhi: RSC's Indian Shakespeare." Rev. of Much Ado about Nothing, dir. Iqbal Khan. The Guardian I August 2012 <url: http://www.guardian.co.uk/culture/2012/aug/o1/muchado-rsc-indian-shakespeare >. Last accessed 15/07/2013.

Kennedy, Dennis and Yong Li Lan eds. 2010. Shakespeare in Asia: Contemporary Performance. Cambridge: Cambridge University Press.

Levith, Murray J. 2004. Shakespeare in China. London: Continuum.

Loomba, Ania 2008. "The Commitment to Shakespeare, or What Are We Celebrating Today?" Shakespeare's World/World Shakespeares: The Selected Proceedings of the International Shakespeare Association World Congress Brisbane, 2006. Newark: University of Delaware Press: 209-222.

MacGregor, Neil 2012. "Director's Foreword." Eds. Jonathan Bate and Dora Thornton. Shakespeare: Staging the World. London: The London Museum Press.

Mackenzie, Ruth 2012. World Shakespeare Festival 2012. World Shakespeare Festival Brochure: 3 .

McLaughlin-Duane, Rebecca 2012. "Much Ado about Nothing spiced up with Meera Syal." Rev. of Much Ado about Nothing, dir. Iqbal Khan. The National 13 May 2012.

<url: http://www.thenational.ae/arts-culture/on-stage/much-ado-abo ut -nothing-spiced-up-with-meera-syal >. Last accessed 16/07/2013.

Massai, Sonia ed. 2005. World-Wide Shakespeares: Local Appropriations in Film and Performance. London: Routledge.

Neely, Carol Thomas 1985. Broken Nuptials in Shakespeare. Yale: Yale University Press.

Orkin, Martin 2005. Local Shakespeares: Proximations and Power. London: Routledge.

Ornstein, Robert 1986. Shakespeare's Comedies: From Roman Farce to Romantic Mystery. Newark: University of Delaware Press.

Purves, Libby 2012. "Much Ado about Delhi." Rev. of Much Ado about Nothing, dir. Iqbal Khan. The Times 3 August 2012: 64 .

RSC: Much Ado About Nothing: Educational Activities Pack.

<url: http://www.rsc.org.uk/downloads/rsc_edu_much_ado_2012_ pack.pdf $>$. Last accessed 16/07/2013. 
- Updates and News. RSC <url: http://www.rsc.org.uk/aboutus/updates/1-5-million-experience-world-shakespeare-festival.aspx $>$. Last accessed 16/07/2013.

"What country, friends is this?" Three Plays by Shakespeare: Educational Activities Pack. RSC <url: http://www.rsc.org.uk/downloads/rsc_edn_ wcfit_2012_teachers_pack.pdf $>$. Last accessed 16/07/2013.

Rushdie, Salman 1991. Imaginary Homelands: Essays in Criticism 1981-1991. London: Granta.

Shahani, Gintanjali 2012. "Fighting the Merry War." Much Ado About Nothing Programme.

Shakespeare, William 1994. Much Ado about Nothing. Ed. Sheldon P. Zitner. Oxford: Oxford University Press.

Singh, Jyotsna 2009. A Companion to the Global Renaissance: English Literature and Culture in the Era of Expansion. Malden, MA: Blackwell.

Singh, Jyotsna 2012. Wooing and Wedding. Much Ado about Nothing Programme.

and Gitanjali G. Shahani 2010. "Postcolonial Shakespeare Revisited." Shakespeare 6/1: 127-138.

Syal, Meera 2012. Moments of Revelation. Much Ado about Nothing Programme.

Trivedi, Poonam 2011. "YYou Taught me Language': Shakespeare in India." Shakespeare Survey 64: 231-239.

- and Minami Ryuta eds. 2010. Re-playing Shakespeare in Asia. New York: Routledge.

Wynne-Davies, Marion 2001. "Introduction." Ed. Marion Wynne-Davies. Much Ado about Nothing and The Taming of the Shrew. Basingstoke and New York: Palgrave.

How to cite this article:

Muñoz-Valdivieso, Sofía. "From Messina to Delhi: Much Ado about Staging Global Shakespeares in Olympic Times." SEDERI 23 (2013): 57-78.

Author's contact: simunozvaldivieso@gmail.com

Submission: 26/11/2012 - Acceptance: 20/04/2013 


\title{
"But Why No Women Write, I Pray?" Sarah Jinner's Defence of Women's Public Voice in Her Almanacs
}

\author{
Susana Oliveira \\ Universidade de Lisboa
}

\begin{abstract}
In seventeenth century England women writers had already been able to move beyond the two genres of writing that had initially been approved for them: translation and devotional literature. It is noteworthy, however, to acknowledge women as authors of almanacs, considering that these writings required a scientific background based upon a specific education in medicine and astrology usually inaccessible to women. Between 1658 and 1664, Sarah Jinner emerged as the first woman author of almanacs. Besides the anticipated prophecies and medical advice, this London astrologer also advocated women's public voice in her works: "But why no women write, I pray?" Jinner used these popular and widely read Early Modern English texts to publicise her defence of women. This paper focuses on Jinner's open challenge to the Aristotelian perspective on women and her defence of women's public voice.
\end{abstract}

KEYWORDS: women, almanacs, seventeenth-century England, astrology, medical advice.

You may wonder to see one of our sex in print, especially in the celestial sciences; I might urge in my defence, yea more than the volume of this book can contain: in which I am confined not to exceed ordinary bulk. $(1658: \mathrm{B} 1 \mathrm{r})^{1}$

\footnotetext{
${ }^{1}$ All of Sarah Jinner's Almanacs excerpts (An Almanack or Prognostication for the year of our Lord 1658, An Almanack or Prognostication for the year of our Lord 1659 and An Almanack for the Year of Our Lord God 1664) are taken from the facsimile edition by
} 
Sarah Jinner's first words to the reader assure that, although breaking the entrenched, idealised silence expected from women, as Betty Travitsky calls it (1990:19), she will maintain both female modesty and virtue - a common defensive attitude that Elaine Hobby points out was a strategy that women of the age were bound to use so their voices could be heard: "making a virtue of necessity: a very womanly thing to do" (1988:1). Jinner further assumes, right from the beginning, the pioneering endeavour that her work represented. Although Louise Curth claims that it is impossible to determine "whether women were actually involved in compiling almanacs, perhaps under pseudonyms" before Jinner's 1658 almanac (68), the available evidence still points to Sarah Jinner as the first woman to have her name associated with the authorship of an almanac. This meant entering male territory, or rather, addressing conventional manly issues, insofar as the "celestial sciences" were concerned. In seventeenth century England, women writers had already been able to move beyond the scope of the two kinds of writing that had initially been approved, or considered suitable, for them: translation and devotional literature. It is noteworthy, then, to acknowledge women as authors of almanacs, considering that these writings required a scientific background based upon a specific education in medicine and astrology usually inaccessible to women. As Suzanne Le-May Sheffield has noted, women's admittance into scientific societies was a "slow and tortuous progression" (2006:155). In the medical field, for example, Barbara Ehrenreich and Deirdre English address the medical professionals' attitude towards women, affirming they were "actively engaged in the elimination of female healers" (2010:50), despite the fact that, as they point out, "male physicians were both more dangerous and less effective than female healers" (2010:16). With respect to midwifery, the numerous attempts to organise a professional guild were unproductive (Eales 1998:82, 83). It is also significant that the Royal College of Physicians of London had made clear, since its foundation in 1518, by a Royal Charter from King Henry VIII, that the admission of women was forbidden, a condition that would only change in 1909, when the first woman was finally admitted to the College (A. M. Cooke 1972:975, 976). Thus, in Jinner's lifetime, the Royal College of

Alan S. Weber (2002). The citations will only include the publication year and the respective page numbers. 
Physicians restricted membership to men who possessed a medical degree and had had a four years' practice, excluding unlicensed practitioners or empirics (Travitsky 1990:13). As Bernard Capp remarks, the connection between medicine and astrology "made the astrologer-physician a respected figure at the courts of kings, princes and popes" (2008:17). To become a skilled astrologer, one had to master the fields of astronomy, astrology and applied mathematics, which evidently involved years of study and training. In addition to these requirements, there was also the extra challenge of facing false accusations of witchcraft. From a historical perspective, Sarah Jinner took a major step in coming forward into the public sphere as the first woman author of almanacs.

Notwithstanding the above-mentioned reasons that substantiate a modern reader's analysis of Jinner's almanacs, another significant factor should be taken into consideration, namely the accuracy of the expression "almanac author," since almanacs contained judicial and natural astrology that were frequently the result of a compilation of other similar writings. In fact, as Adam Smyth observes, "the figure of the almanac compiler was ridiculed" and often associated with "hollow claims of learning," although certain compilers may have had a "vivid cultural presence" $(17,18)$. Hence, this common practice regarding these publications may lead the contemporary reader to question the precise extent of Jinner's authorship of the almanacs published under her name. In her study of almanacs, Louise Curth tellingly uses the expression "purportedly written by women" when referring to the topic of authorship (67). In this regard, I would like to put forward two different arguments pertaining to Sarah Jinner's authorship in this case.

First, even if one discards the sections more susceptible of compilation - for example, those regarding the astronomical tables, the general astrological information, and those containing prophecies and medical advice - Jinner's almanacs still have a distinguishing particularity when compared to other women's almanacs, such as Mary Holden's or Dorothy Partridge's, namely the personalised "To the Reader" addresses in the 1658 and 1659 almanacs. ${ }^{2}$ Here, Jinner addresses her readers directly, in a discourse

\footnotetext{
${ }^{2}$ Mary Holden's almanacs (1688 and 1689) were published thirty years after Jinner's first almanac and Dorothy Partridge's single almanac was published even later, in 1694. Louise Curth offers a stimulating account for that long intermission between the
} 
focused on women - "our business;" "our sex" (1658:B1r-B1v) intertwined with gender provocations and a humorous tone: "Though some witty coxcombs strive to put us out of conceit of ourselves;" "we will not boast of strength of body, let horses and mules do that." She further defends the importance of women in society and their rightful claim to learning; she presents a lengthy female genealogy of influence in all areas of human intellectual activity, from the political field to philosophy, physics and literature (1658:B1r-Biv). Taking all this into consideration, in my view it becomes more difficult to dismiss the striking distinctiveness of a woman's voice behind these texts speaking in defence of womanhood. Indeed, it is striking that Jinner herself signs this section with her initials, "S.J." (1658:B1v; 1659:A).

Now, focusing on the other sections of Jinner's almanacs, further evidence is found in favour of her authorship. The fact that Jinner's almanacs are clearly female-oriented is further substantiated by the comparison with the content of the almanacs published by other women, like Mary Holden and Dorothy Partridge. Jinner compiles a substantial number of ailments, recipes, advice and instructions concerning women's disorders, maladies and problems, advocating women's rights over their own bodies; this might be taken as further supporting the view that they are written by a woman. Jinner's 1658 almanac is, according to Curth, "the secondlargest collection of medical remedies" $(170)^{3}$ and in the 1659 almanac Jinner presents forty-four new recipes, all of which consider women "a major focus" (171), unlike Holden's and Partridge's almanacs, whose advice addresses male and female maladies alike. The volume of advice dedicated to women is, therefore, too significant to ignore the probability of Jinner's authorship of these almanacs. Thus, as Louise Curth points out, only Jinner's almanacs were definitely written by a woman, as opposed to those published under Mary Holden's and Dorothy Partridge's names (59). ${ }^{4}$ Bringing

publications of these three "women-authors" of almanacs, arguing that Holden's and Partridge's almanacs were not really authored by women, but published by the stationers in the hope of repeating the financial success of Jinner's first almanacs. For more on the case study of women's almanacs, see Curth (2007:67-78).

${ }^{3}$ The first being Gabriel Blunt's 1657 almanac, according to Curth's study (2007:170).

${ }^{4}$ Louise Curth raises the question of Jinner's authorship in regard to the 1664 almanac. When comparing the content of the 1664 publication with the previous ones, three inconsistencies become evident in the latter: there is no preface or any editorial 
the argument full circle, Jinner's almanacs remain a significant piece of evidence concerning Early Modern women's representativeness that ought to be explored further.

I will focus on Jinner's open challenge to the Aristotelian perspective on women, as well as on her defence of women's freedom of choice. One could argue that almanacs were not expected to contribute significantly to this matter, but I would like to stress a different point of view: Jinner did find a means to publicise her defence of women through her almanacs.

A. S. Weber's The Early Modern Englishwoman: A Facsimile Library of Essential Works, Volume 6, Almanacs is the resource through which work on Jinner is possible, since it provides access to the original texts. There are four surviving almanacs by Sarah Jinner: $A n$ Almanack or Prognostication for the year of our Lord 1658; An Almanack or Prognostication for the year of our Lord 1659; An Almanack for the year of our Lord God 1664; 5 and a fourth, from 1660, lacking a considerable portion of text. This last has two surviving copies, located in the British and Yale libraries, but it is not reproduced in facsimile version. Consequently, I will make reference only to the almanacs whose original texts are available as facsimile reproductions.

All three almanacs are octavos, which according to Capp became the "standard form" for almanacs (2008:27). Each is 40 pages in length, composed of similarly distinctive sections, which followed the conventions of male-authored almanacs, that is, they were divided in two main sections: the first part composed of the ephemeris, or astronomical tables (a detailed calendar set out as monthly tables), preceded by general astrological information; and

comment (or, as mentioned above, there is no "To the Reader" address); a different pattern in the recipes and medical advice is noticeable (most of them are recycled from the 1658 and 1659 almanacs); and there is "rather misogynistic advice," clearly absent from the previous texts (70). Other discrepancies between the almanacs of 1664 and those of 1658 and 1659 pointed out in this article might support Curth's conclusion, and despite the lack of corroborating evidence, Curth's argument is compelling. However, in the light of other studies of almanacs, such as those presented by Capp, Weber and other scholars referred to in this article, I maintain that the 1664 almanac was inspired - if not authored - by Jinner.

${ }^{5}$ The facsimile versions in Weber's volume are reproductions of the following copies: An Almanack or Prognostication for the year of our Lord 1658, at the Guildhall Library; An Almanack or Prognostication for the year of our Lord 1659, at the Huntington Library; and An Almanack for the year of our Lord God 1664, at the Edinburgh University Library. 
the second part containing the astrological prognostications or prophecies. Jinner's almanacs include a section dedicated to physical observations or medical advice and the 1658 and 1659 texts contain the address "To the Reader." The latter is a personalised and distinctive section of Jinner's almanacs, what we might consider her "hallmark" in which she addresses her readers directly in a humorous and straightforward tone.

Each text has passages in both black letter ${ }^{6}$ and roman type, a mixture of fonts which was common at the time, as Mark Bland observes, since "an average printing-house had anywhere from 15 to 25 cases of type," the most common being black letter, roman and italic (2010:109). In the 1659 text, a visible formatting mistake appears in the running-title of page B3r: "[A Prognostication] for the Year 1656" can be read instead of "[A Prognostication] for the Year 1659," an example of how the compositor distractedly inverted the position of the numeral(s) 6/9 in the box of the printing plate. Another peculiarity regarding the text format of the three almanacs is related to pagination: many pages are identified with a letter, or a letter to which is added a number, when part of the same almanac section, but a significant number of pages has no designation, which makes accurate quotation an extremely difficult task. The graceful lady portrait on the front page of the 1658 and 1659 almanacs as well as the identification of the author as a "student in astrology" constitute two other common characteristics of Jinner's texts. As Weber remarks, the "student" corresponds to our modern "scholar" (2003:363), hence emphasising the significance of Jinner's intellectual knowledge. Louise Curth further observes that emphasising one's "credentials" on the title page of the almanac was a way for authors "to create a persona for themselves as knowledgeable experienced astrologers" (73). Certainly Sarah Jinner intended to be taken seriously. That she was taken seriously and that her reputation was well known can be inferred from the fact that her two first almanacs were - as advertised on the front page - "calculated for the Meridian of London, and may indifferently serve for England, Scotland and Ireland," while her 1664 almanac was publicised, with distinctive

\footnotetext{
${ }^{6}$ Paul Shaw and Peter Brain observe that the use of the terms "Old English" and "Gothic" to refer to black letter type is often misleading and only partly accurate (1998:10). For the social and cultural meanings associated with the use of black letter versus roman type, as well as for the transition from the first type to the latter, see Stanley Morrison (1942), Charles C. Mish (1953), and Mark Bland (1998).
} 
capital letters, as an astrological calculation serving "for all EUROPE." Besides adding to the increasing author's credibility, this could also lead us to reflect upon the progressively widespread circulation of Jinner's almanacs. Elaine Hobby has also pointed out that since Jinner's almanacs continued to be published until at least 1664, one can assume that she displaces Aphra Bhen as the first woman to depend financially on her writings (1998:182). Furthermore, the army Captain Henry Herbert made reference to a Sarah Jinner as "[a] well-known practising London astrologer" in 1673 (Weber 2002:x, xi). All in all, Jinner becomes an inescapable woman author whose texts ought to be looked into.

Though ephemeral texts "discarded in December," "tailored to a year, a place and an intended audience," as Lauren Kassel notes (2011:432), almanacs reached a wide public encompassing all social and economic groups; they became the best-selling books of the midand late-seventeenth centuries, with sales, according to Capp, that "exceeded 400,000 a year in the 1660s" (2008:44). With regard to their actual readership, however, there is a much greater difficulty in providing evidence as to who bought, read and owned these publications, precisely due to their ephemeral nature. Margaret Spufford acknowledges the "obscurity" surrounding this subject (258), although she observes that a "female readership of an unknown size" - as opposed to the estimated 30 per cent of male readership - played a decisive role in stimulating the publication of ephemera, such as almanacs (22). Louise Curth further observes that "almanac writers provided clues as to the types of audiences that they were trying to reach" (79). Jinner's almanacs were clearly female-oriented and the success of her first almanac is strongly implied in "To the Reader" in the 1659 almanac, thus confirming that women were, in all likelihood, Jinner's principal readers.

Sarah Jinner's almanacs were published in London, during the Civil Wars and the Restoration. In this period of political turmoil, Jinner captivated the attention of her audience with an evocative message:

But why no women write, I pray? Have they not souls as well as men? Though some witty coxcombs strive to put us out of conceit of ourselves as if we were but imperfect pieces, and that nature, intending a man, when the seminal conception proves weak there issues a woman. (1658:Bir) 
Behind Jinner's open challenge to the patriarchal system lies a very complex and troubling belief that held women to be inferior human beings, as asserted in the renowned anonymous tract, most certainly familiar to Jinner, Disputatio nova contra mulieres. Through the rhetorical question, Jinner further implies the answer to the debate on the topic of whether or not women have souls. Jinner is plainly confronting the feminine archetypes proclaimed by the scholastic theological and philosophical frame of thought, which regarded woman as an incomplete version of the male, an imperfect and deformed man, or, as stated in Aquinas' defence of the Aristotelian idea, "the female is a misbegotten male," "produced incidentally and beside the intention of nature" (1921:190-191). Although a contextualised and detailed analysis of both Aristotle's and Aquinas' texts in their original languages may lead to other readings - rather more sympathetic towards women, in fact, as proposed by Michael Nolan $^{7}$ - we can detect in Jinner some similarities with the same "feminist" light still predominant in gender studies. In fact and to a considerable extent, Jinner anticipates the critiques that Simone De Beauvoir and other contemporary authors, make of those same Aristotelian and Aquinean (mis)conceptions of women (1997:15,16).

Additionally, Jinner is also directing the reader to the everpresent debate regarding women and woman's responsibility for the fall. According to the Jewish-Christian Bible, and subsequently to the concordance of the Fathers of the Church and the scholastic community, Eve was considered more responsible for the original sin than Adam. Moreover, as Tertullian argued, each woman should be considered another Eve and therefore the inheritor of her sin and guilt (2004:3). In addition, Saint Paul had plainly indicated that all women should "learn in silence with all subjugation" (First Epistle to Timothy 2:11-14). Not only does Jinner resolve to "break the entrenched silence," as previously mentioned, but significantly she also chooses to address openly a sensitive gender topic in order to subvert it, and she does so in an antagonistic tone to further urge her readers to (re)act against the prevailing male attitude towards women.

7 Nolan has written extensively on the "myths" and misconceptions vis-à-vis Aristotle's and Aquinas' texts regarding women (1993; 1999). 
Then, Jinner turns to a more inspirational and supportive rhetorical approach:

But know that Aristotle affirms that women doth contribute to formation matter as well as place. Mankind is preserved by women, many other rare benefits the world repeath by women, although it is the policy of men to keep us from education and schooling, wherein we might give testimony of our parts by improvement: we have as good judgement and memory, and I am sure as good fancy as men, if not better. (1658:Bir)

As Ian Maclean observes, in Aristotle's dichotomic interpretation of men's and women's existence, men are associated with active and formative characteristics, while women are "passive, material and deprived, desiring the male in order to become complete" (1980:7). In this context, Jinner chooses a conciliatory approach and avows to her readers that women play an important role within the framework of Aristotelian thought after all, since women provide (hu)mankind with both existence and completeness. Subsequently, in a rather humorous way, Jinner appeals to female agency and urges women to cherish their key role in humanity, to think highly of themselves, regardless of male-imposed constraints. She encourages women to focus on their qualities and potential accomplishments - not on their faults or under-achievements. Although Jinner mentions that men's policy is to deprive women of education, she is almost certainly referring to women's lack of access to classical medical learning in universities. In fact, the institutionalised attempt to maintain man's monopoly over Latin and Greek medical knowledge was "[the] only distinguishing advantage of the university-trained physician, and the sole claim to his medical superiority and high fees" (Weber 2003:368, 375). In this context, Jinner's use of Latin in the "Physical Observations" of 1664 is significant, since the inclusion of that particular element associates her work with the authority conferred by and through classical knowledge and indicates the rising status of her scholarship. It can be further demonstrated that Jinner's comment on women's impediments in schooling is not to be generally applied by the fact that she addresses her work to a female audience, hence exploiting the growth in women's literacy and education. This is underscored when she praises women writers of the time - Margaret Cavendish, Katherine Philips, and Elizabeth Grey (1658:B1r-B1v), whose collection of medical recipes had been published in 1651, with 
several additional reprints, under the title A Choice Manual, or Rare Secrets in Physic and Surgery.

As previously mentioned, in this 1658 "To the Reader" address Jinner inspires women to flourish and succeed by presenting a mesmeric inventory of women's names, whose achievements in the various fields of the public sphere might be followed: the Amazons, Semiramis, Tomiris, Queen Elizabeth Tudor, Elizabeth Grey, Margaret Cavendish, Catherine Philips, and even, as Jinner puts it, "a pope of our sex, named Pope Joan, [whose existence] the best historians do not deny" (1658:B1r-B1v). Again, Jinner is suggesting that women should place themselves outside the "mainstream" archetypal models of conduct assigned to them: passivity, submission, silence. Jinner is actually offering her readers the possibility to pause and ponder on the numerous examples of women who decided against feminine dependence and broke free from patriarchal dominance. It is possible for a woman to show she is on the same level as men, to perceive herself as the authority, not only over herself, but also over her family, or even the political and religious forces of a nation. After all, "Pope Joan," Queen Elizabeth, the Amazons, and the others listed by Jinner did so. These examples are then the ancestors of Jinner's readers', a matriarchal family tree that is, as the author construes, women's decision to create. If a woman's true vocation is not submission, then she must overcome the ideological discourses that bind her to the private sphere, and claim her place and role in the public domain. In the light of Terry Eagleton's observation that "there is indeed an internal relation between being a woman (a social situation) and being a feminist (a political position)" (211), Jinner's advocacy of women's public voice is evident in her forward-thinking "feminist" discourse.

Significantly, the corollary of Jinner's proposed matriarchal lineage is Queen Elizabeth I. In a rather scornful tone, she explains why England was going through such difficult times:

When or what Commonwealth was ever better governed than this by the virtuous Queen Elizabeth? I fear me I shall never see the like again, all you princes nowadays are like dunces in comparison of her: either they have not the wit she had or the honesty she had: something is the matter that things do not fadge so well! (1658:Bir) 
Here, Jinner connects past, present and future, adopting a more political tone and opposing the Queen's political and personal excelling qualities to the current political governors' inability and lack of moral values, allowing the reader to infer that the current situation is unlikely to be improved with new leadership of the commonwealth. Although Jinner was no "sectary" (Hobby 1988:182), she assumes and promotes a political public voice for women in passages like this one throughout her almanacs. Capp refers to Jinner's vigorous social and political commentary, suggesting that she held an anti-authoritarian position (2008:87). In fact, in her 1659 almanac, she predicts in the astrological observations for July that "from all parts we hear of desperate unreconcilable wars" (1659: $\mathrm{C} 2 \mathrm{v}$ ); then, under the astrological observations for October she states that although she wishes no uprising, she admits "that a people are not bound to obey well, when governors do not govern well" (1659:C $3 r$ ). Later on, in the astrological observations for November she urges, "Come let us all amend, the world is bad enough," and, after mentioning the King of Spain, the French and the Dutch, she ends up her considerations in London, whose politicians she describes as "mare makers of discontent" (1659:C3V). Jinner's ideological and political affiliations during this troubled period might also be inferred by her choice of publisher: all her almanacs were printed by John Streater for the Company of Stationers. Streater was an English soldier, pamphleteer, and political writer in the 1650 s, openly hostile to Oliver Cromwell. As Jason Peacey notes, Streater was a "key republican critic of the regime, whose works had attracted the attention of the authorities" (2004:200). According to Joad Raymond and Nigel Smith, Streater represents "the turning of the Leveller diaspora into the classical tradition to produce a genuine popular republicanism" (Raymond 1998:567-574; Smith 1995:137-155). This information may contribute to a deeper and clearer understanding of her political beliefs and observations. Jinner was politically aware and active; as a woman writer she inspired her counterparts to adopt a similar mind-set towards the strangest of times in which they were living. Jinner's attitude confirms Susan Wiseman's observation that despite women's exclusion from the political sphere, they "consistently influenced the discourse on and of politics" (2006:9), to which category we might therefore add Jinner herself. 
Another important and significant element of these almanacs is Jinner's dispensation of medical advice. Although she also provides such advice for men, her recipes are female-oriented and concentrate on women's concerns with conception, pregnancy and numerous infections, as well as recipes for women's cosmetics, for example how "to take away pimples" or how to "make the skin fair and shining" (1664:B7v). Jinner does not exclude psychological considerations concerning women's welfare, providing remedies for "the corrupt humors" as well as for the "prevention of quarrels between Men and Wife," for example (1659:B8r; 1664:B7r). She also provides instructions for potions that "provoke the Terms," for the "further conception in a woman," to "expel a dead child," to "dry up the milk," and to "take away the desire of a woman to the Act of Venery" (1558:B5r-B8v; 1559:B4r-B8v; 1664:B3r-B8r): all medicallyrelated concerns for women, who were - and, generally speaking, still are - considerably more distressed and burdened regarding sexually-related issues than men. In this respect, one might consider the specific issue of abortion. Jinner's recipes to "provoke the terms" (menstruation) or "to expel a dead child" contained abortifacients pennyroyal and mugwort (1658:B5r,B5v; 1659:B6r; 1664:B3r). Although early modern practitioners were ambivalent about the practice of abortion (Evelyne Berriot-Salvadore 2000:348-349) they knew that women might use the remedies provided in a certain context to suit their needs in a quite different way. As Chantelle Thauvette notes:

Regardless of whether Jinner's readers actually used Jinner's recipes to abort or induce premature labor, we may conclude that the combination of watching the calendar and recipes gave women options in managing their own reproductive and menstrual cycles without having to subject themselves to scrutiny from a culture likely to link any gynaecological ailment to a woman's sexual (mis)conduct. (2010:246)

Thus, more than ephemera to be discarded at the end of the year, Jinner's almanacs might have functioned as a practical reference and advice book for women to achieve a degree of freedom of choice over their reproductive lives.

Jinner's almanacs were, therefore, deeply focused on a female audience for which they were in large part intended, taking into serious account women's wellbeing as a whole: the physical, the psychological and the intellectual condition of her female readers 
was a dominant concern. Moreover, Jinner addressed these wideranging matters in a discourse in the 1658 almanac that may have appeared to some as rather too clear and open, for in the following year's almanac Jinner declares: "Therefore this year, I here present you with some other of the like nature [predictions; physical cures], avoiding such language, as may, perhaps be offensive to some" (1659:B1r). Once again, the question of women's display of modesty and virtue was at stake, even more so since the language associated with gynaecology, conception, breast-feeding and other sexualrelated matters might be considered too explicit and offensive. Jinner did, nevertheless, underline the main purpose of her advice, emphasising the consequences of taking modesty in the medical field too seriously: "It is not fit the world should be deprived of such helps to Nature; for [...] many, by their Modesty, suffer much" (1659:B1r). By referring to women's physical matters in plain English, Jinner provided her readers with a certain type of knowledge they might not obtain otherwise, be it through the medical authorities Jinner used as her sources or through the reading she recommends, like Levinus Lemnius's 1559 The secret miracles of nature (1659:B1r). She further states that her main aim is "that our sex may be furnished with knowledge: if they [women] knew better, they would do better" (1659:Bir).

Sarah Jinner thus offers a feminine public voice for the seventeenth century, perhaps even in some respects a forwardthinking "feminist," as we might be inclined to call her today. Towards the conclusion of her 1658 "To the Reader" address, Jinner reiterates the underlining message that may be perceived in all her almanacs, namely a captivating and inspirational assertiveness promoting the harmony of the spheres through women's action: "Let us scour the rust off by ingenious endeavouring the attaining higher accomplishments [...] so by this means we should have an excellent world [...] Farewell till next year" (1659:B1v).

\section{References}

Aquinas, Thomas 1921. Summa theologica. Third Part (Supplement). Trans. Fathers of the English Dominican Province. London: Burns Oates \& Washbourne.

Bland, Mark 2010. A Guide to Early Printed Books and Manuscripts. Malden and Oxford: Wiley-Blackwell. 
S. Oliveira

— 1998. "The Appearance of the Text in Early Modern England." Eds. W. Speed Hill and Edward M. Burns. Text: An Interdisciplinary Annual of Textual Studies, Volume 11. Michigan: University of Michigan Press: 91155.

Berriot-Salvadore, Evelyne 2000 (1993). "The Discourse of Medicine and Science." Eds. Natalie Davis and Arlette Farge. A History of Women in the West: Renaissance and Enlightenment Paradoxes. Cambridge and London: Harvard University Press: 348-388.

Capp, Bernard 2008 (1979). Astrology and the Popular Press: English Almanacs 1500-1800. London: Faber and Faber.

Cooke, A. M. 1972. A History of the Royal College of Physicians of London: Volume III. Oxford: Clarendon Press.

Curth, Louise Hill 2007. English Almanacs, Astrology and Popular Medicine: 1550-1700. Manchaster and New York: Manchester University Press.

De Beauvoir, Simone 1997 (1949). The Second Sex. Trans. and Ed. H. M. Parshley. London: Vintage.

Eales, Jacqueline 1998. Women in Early Modern England: 1500-1700. London: University College London Press.

Ehrenreich, Barbara and Deirdre English 2010 (1973). Witches, Midwives, and Nurses: A History of Women Healers. New York: Feminist Press.

Habermas, Jürgen 1991. The Structural Transformation of the Public Sphere: An Inquiry into a Category of Bourgeois Society. Trans. Thomas Burger. Cambridge: MIT Press.

Hobby, Elaine 1988. Virtue of Necessity: English Women's Writing 1649-88. London: Virago Press.

Kassel, Lauren 2011. "Almanacs and Prognostications." Ed. Joad Raymond. The Oxford History of Popular Print Culture Volume One: Cheap Print in Britain and Ireland to 1660. Oxford: Oxford University Press: 431-442.

Maclean, Ian 1980. The Renaissance Notion of Woman: A Study in the Fortunes of Scholasticism and Medical Science in European Intellectual Life. Cambridge: Cambridge University Press.

Mish, Charles C. 1953. "Black Letter as a Social Discriminant in the Seventeenth Century." PMLA 68: 627-630.

Morrison, Stanley 1942. "Black-letter" Text. Cambridge: Cambridge University Press.

Nolan, Michael 1999. Aquinas' Philosophy of Man and Woman. Dublin: Four Courts Press. 
— 1993. "The Mysterious Affair at Mâcon: The Bishops and the Souls of Women." New Blackfriars 74/876: 501-507.

Peacey, Jason 2004. Politicians and Pamphleteers: Propaganda During the English Civil Wars and Interregnum. Hampshire and Burlington: Ashgate.

Raymond, Joad 1998. "John Streater and the Grand Politick Informer." The Historical Journal 41/2: 567-574.

Shaw, Paul and Peter Brain eds. 1998. Blackletter: Type and National Identity. New York: Princeton Architectural Press.

Sheffield, Suzanne Le-May 2006 (2004). Women and Science: Social Impact and Interaction. Santa Barbara: Rutgers University Press.

Smith, Nigel 1995. "Popular republicanism in the 1650s: John Streater's "Heroick Mechanicks." Ed. David Armitage. Milton and Republicanism. Cambridge: Cambridge University Press: 137-155.

Smyth, Adam 2010. Autobiography in Early Modern England. Cambridge: Cambridge University Press.

Spufford, Margaret 1981. Small Books and Pleasant Histories: Popular Fiction and its Readership in Seventeenth-Century England. Cambridge: Cambridge University Press.

Tertullian 2004. On the Apparel of Women. Trans. Rev. S. Thelwall. NP: Kessinger Publishing.

<url: $\quad$ http://books.google.pt/books?id=geOoHJBUygwC\&q=eve\#v= snippet\&q=eve\&f=false $>$. Last accessed 18/04/2013.

Thauvette, Chantelle 2010. "Sex, Astrology and the Almanacs of Sarah Jinner." Early Modern Women: An Interdisciplinary Journal 5: 243-249.

Travitsky, Betty 1990. "Placing Women in the English Renaissance." Eds. Anne M. Haselkorn Betty Travitsky. The Renaissance Englishwoman in Print: Counterbalancing the Canon. Amherst: University of Massachusetts Press: $3-44$.

The Holy Bible 2003 (1611). Authorized King James Version. NP: Thomas Nelson, Inc.

Weber, Alan S. ed. 2002. The Early Modern Englishwoman: A Facsimile Library of Essential Works, Series II, Printed Writings, 1641-1700: Part I, Volume 6, Almanacs. Aldershot: Ashgate.

— 2003. "Women's Early Modern Medical Almanacs in Historical Context." English Literary Renaissance 33/3: 358-402. 
S. Oliveira

Wiseman, Susan 2006. Conspiracy \& Virtue: Women, Writing and Politics in Seventeenth-Century England. Oxford and New York: Oxford University Press.

How to cite this article:

Oliveira, Susana. "'But Why No Women Write, I Pray?' Sarah Jinner's Defence of Women's Public Voice in Her Almanacs." SEDERI 23 (2013): 79-94.

Author's contact: spoliveira17@gmail.com

Submission: 29/10/2012 - Acceptance: 20/05/2013 


\title{
Cymbeline: Arithmetic, Double-Entry Bookkeeping, Counts, and Accounts
}

\author{
Patricia Parker \\ Stanford University
}

\begin{abstract}
The importance of commercial arithmetic and double-entry bookkeeping (or "debitor and creditor" accounting) has been traced in The Merchant of Venice, Othello, the Sonnets, and other works of Shakespeare and his contemporaries. But even though both are explicitly cited in Cymbeline (the only Shakespeare play other than Othello to invoke double-entry by its contemporary English name), their importance for this late Shakespearean tragicomic romance has yet to be explored. This article traces multiple ways in which Cymbeline is impacted by arithmetic and the arts of calculation, risk-taking, surveying, and measuring; its pervasive language of credit, usury, gambling, and debt, as well as slander infidelity and accounting counterfeiting; the contemporary conflation of the female " $\mathrm{O}$ " with arithmetic's zero or "cipher" in relation to alleged infidelity; and the larger problem of trust (from credere and credo) that is crucial to this play as well as to early modern England's culture of credit.

KEYWORDS: Cymbeline, Shakespeare, double-entry bookkeeping, Hindu-Arabic numbers, arithmetic, military science, feminist criticism, gender, transvestite theatre, knowledge production, rhetoric, mathematics, history of accounting, economic criticsm.
\end{abstract}

The importance of arithmetic and double-entry bookkeeping for Shakespeare has been traced in The Merchant of Venice, the Sonnets, and other works. ${ }^{1}$ But though Cymbeline explicitly cites both, their

I See inter alia Parker (1987:132-140; 2004:25-49; 2009:223-241); Bady (1985:10-30); Woodbridge (2003:1-18; 2010:328-329); Glimp and Warren (2004); Blank (2006:118152); Korda (2009:129-153); Raman (2008:158-80; 2010:212-231). 
importance for this late play has still to be explored. This article will argue that the new "arithmetic" and "debitor and creditor" or double-entry accounting are crucial for Cymbeline, the only play in the canon other than Othello $(1.1 .19,31)$ to invoke both "arithmetic" (2.4.142) and "debitor and creditor" accounting by its contemporary name (5.3.228-229). ${ }^{2}$ It will also foreground preoccupations that bring this tragicomic romance closer to other Shakespeare plays that have been the focus of commercial and economic criticism.

As the form of counting (arithmos) "used by merchants or bankers when buying or selling in the marketplace" (Jaffe 1999:29), arithmetic was identified with mercantile calculations and the Hindu-Arabic numerals, including the sifr, cipher, or zero. Robert Recorde (1543:6) noted that some call it "Awgrym for Algorisme (as Arabyans founde it)." Despite its advantages over tally-sticks, counters, and Roman numerals, there was "bitter resistance" to this so-called "infidel" system (Bernstein 1996:35). In England, this "new arithmetic of the pen," with its "strange and unfamiliar" numerals, was resisted well into the seventeenth century (Thomas 1987:120121). Arithmetic and double-entry treatises continued to include "counters" for "such as lacke the knowledge of Arithmetike by the Penne" (Mellis 1588: A7v), a combination reflected in the "counters" and "pen" reckoning of Cymbeline (5.3.228-230), as well as in Florentine Cassio as both "counter-caster" and "arithmetician" in Othello (1.1.31).

Central to this resistance was the "infidel symbol" zero (Rotman 1987:8), "sign for what was not" (Crosby 1997:113), identified through "cipher" with enigmatic signs or writing to be "deciphered" (Jaffe 1999:87) in ways suggestive for Cymbeline's enigmas and decipherings. Written like the letter " $\mathrm{O}$ " (Menninger 1969:412), it was associated with the female sexual " $\mathrm{O}$ " or "count" and feared infidelity of this hidden "nothing" or "country matters" (Hamlet 3.2.116). The "cipher" of this new place-based arithmetic is able to "Attest in little place a million" in Henry $V$, where actors on the Globe's "wooden O" become "ciphers" to a "great accompt" (Prologue 15-17) and "le count" of Katherine's female body joins the

\footnotetext{
${ }^{2}$ Evans (1997) is cited for Shakespeare plays other than Cymbeline (cited from Butler 2005). Butler retains Folios' Iachimo; but changes Imogen to Innogen (suggesting "innocence"), wife of Leonato in Much Ado About Nothing, and familiar from Cymbeline's sources and Simon Forman's 1611 account.
} 
inventory of Henry's hoped-for possessions (3.4.51-59) (Parker [1987:138]; Turner [2006:10]; Parker [2009:232, 236-237]). Othello fears that Desdemona has "the act of shame|A thousand times committed" (5.2.212). In The Winter's Tale, the "cipher" able to "multiply" one into "many thousands more" figures not only a "debt" but the "rich place" of Hermione's pregnant body (1.2.6-8; Parker 2004:39); and the feared infidelity of this " $\mathrm{O}$ " spirals into Leontes' jealous "nothings" (1.2.284-296). In Cymbeline, when Posthumus concludes that Innogen has turned "whore," his "Spare your arithmetic, never count the turns. |Once, and a million!" (2.4.142143) echoes the sexual "turns" of Othello (4.1.252) and the female "count" of Henry $V$.

Suggestively for Cymbeline's preoccupation with sexual, epistemological, and cognitive knowing, "vulgar Arithmeticke" brought the unknown "thing" to light; and this $\cos a$ or "thing" was linked to uncovering a female res or thing (Bady 1985:11; Parker 2009:228). Iachimo's account of Innogen's "chamber" (2.4.81) convinces Posthumus he has had carnal "knowledge" of her (2.4.51). "Arithmetic" was identified with sexual "commerce" as well as what Measure for Measure called "the two usuries" (3.2.5), sexual and monetary (Hawkes 2010:164-165). "Turnbull Street whores" were described as practicing "arithmetic"; the "Arithmaticke" of a "Bawd" included carnal as well as commercial "Divisions \& Multiplications" (Williams 1994:2.863-864). The association of arithmetic with usury of both kinds is reflected not only in Othello (2.1.130), but in Cymbeline as well, a play whose pervasive language of debts includes "the city's usuries" (3.3.45) but also the sexual debt de mariage that Posthumus fears has been paid to another. ${ }^{3}$

Famously anachronistic, Cymbeline combines ancient Britain and Augustus Caesar's Rome with a "bourgeois" wager plot from Florentine Boccaccio's Decameron and the anonymous Frederyke of

\footnotetext{
3 On marital sexual "debt," "interest," and usury, see Fischer (1985:51) ("cancel"); Korda (2009:151-152). On Cymbeline's language of debt and commerce, see Spurgeon (1935:296-300); Parker (1987:132-137); Siemon (1994:294-309); Stanivukovic (1998:229243); Wayne (2002:288-315); Ryner (2008:77-94); Gillen (2011:1-38). Its "bonds" include marital bonds, what is owed by daughter to father ("duty [...] unpaid," 3.5.48), servants to masters (5.1.7), obligatio, religio, and other ties that bind (e.g. 3.7.15). "His steel was in debt, it went o'th'backside the town" (1.2.8) connects bodily backside to backstreets where debtors evade creditors.
} 
Jennen or Genoa. ${ }^{4}$ The name choice "Europhile" (4.2.233) is joined by the Europeans of the wager scene, which includes "a Dutchman," " $a$ Spaniard" (1.4.0 SD), a "Frenchman," Posthumus the "Briton," and the "Italian" gentlemen Philario and Iachimo, later identified as "Siena's brother" (4.2.340). Siena, like Florence, Venice, and Genoa, had a long history of the rise of merchants and merchant-bankers to the status of aristocrats and "gentles," as well as connections to the commercial "arithmetic" and "debitor and creditor" accounting that Cymbeline invokes.

The association of "arithmetic" with merchants and trades rather than "gentles" (Woodbridge 2003:3; Blank 2006:124) is part of the double perspective in Cymbeline on Cloten's arithmetical deficiencies, which suggest his class disdain for "numbers" while ridiculing his ineptitude at calculation, in contrast to his mother the Queen who is always "coining plots" (2.1.53) and the calculating Iachimo identified with early modern Italy. Not just merchants, however, but even aristocrats and "gentles" were increasingly part of England's "culture of credit" (Muldrew 1998), which included not only commercial arithmetic but also wager-laying, including betting on horses, cards, dice, and dueling (all alluded to in Cymbeline). ${ }^{5}$ Cloten, Posthumus, and Iachimo engage in gambling with differing degrees of skill; the war against Rome is improbably won against high odds; and the play's wager, risk-taking, revenge, slander, and other plots repeatedly invoke not only "arithmetical" reckonings, credits, debts, and accounts both financial and narrative, but also military risk-taking, the "hazard" $(1.4 .76 ; 4.4 .6)$ Guiderius complains he and his brother have been kept from, before their crucial role in defeating the invading Romans.

The new arithmetic-where value depended on place because its "figures" acquired a different value depending on their placement was identified with "place" more generally in contemporary writing,

\footnotetext{
4 See Wayne (2008:163-187) on these and other wager stories; Parker (1989:189-104); Parolin (2002:188-215).

${ }^{5}$ Although her more detailed play analyses do not include Cymbeline, Woodbridge (2010:61-126) on arithmetic, double-entry, gambling, "bonds," debts, and revenge as "pay-back" provides suggestive contexts for it. Bernstein (1996:39-56) traces gambling risk calculation and probability theory from Pacioli (1494) to Italian arithmetician/ gambler Girolamo Cardano (on whom see also Bady [1985:12]; Woodbridge [2003:8] on his 1552 visit to England).
} 
including hierarchical or social place and upward or downward mobility (Parker 2009:226), major preoccupations in Cymbeline. At the same time, it was bound up with other developments that required calculating and measurement, in ways Cymbeline reflects, including visual perspectives, land surveying, military science, and "debitor and creditor" accounting. This play's intersections of "place" and "perspective" are underscored in Wales, where Belarius's "it is place which lessens and sets off" (3.3.13) combines hierarchical "place" with the eye's viewing or vantage point. "Debitor and creditor" bookkeeping is invoked here, from Belarius's perspective, in his rejection of "the city's usuries" (3.3.45) and debts "uncrossed" in a double-entry ledger "book" (3.3.26); but the reverse perspective of Guiderius sees their rural "cell of ignorance" as a "prison for a debtor that not dares | To stride a limit" (34-35).

Visual perspectives are repeatedly evoked in Cymbeline, not only in the different ways characters look (both objectively and subjectively), but also in act 5 , where "debitor and creditor" accounting is invoked in relation to what is "true" (5.3.228). Posthumus forgives Innogen for "wrying but a little" (5.1.5) after he is convinced by the "bloody cloth" (5.1.1) that she has been murdered as he ordered. But "wrying" as a term subtly recalls Richard II, on the importance of looking at "perspectives" themselves "awry," since they show "nothing but confusion" when "rightly gazed upon" (2.2.18-20). And Innogen has never actually been "awry," crooked or obliquely turned, in the sense of sexual infidelity Posthumus's "wrying" continues to assume.

Cymbeline's evocation of land surveying combines perspective with arithmetical calculation. It repeatedly recalls moments in Virgil's Aeneid when tracts of land (or time) are surveyed from a superior vantage point, a central scopic image of Roman imperium. Jupiter's overarching perspective on the plot of Aeneas's trials is recalled in the descent of "Jupiter" in Cymbeline 5.3 (Parker 1989:194).

\footnotetext{
6 Turner (2006:166-169) on the verbal creation of visual perspective in King Lear is suggestive for Cymbeline as well. See also Cymbeline's references to "mapped" (4.1.2); counting or numbering (1.6.37), including military "numbers" (3.7.15; 4.2.342); "quantity" and "weight" (e.g. 4.2.17); and measuring (1.1.27; 1.2.16; 2.4.113; 3.6.62).

7 Leon Battista Alberti, designer of spaces, secret ciphers, and visual perspectives, lived late in life with Pacioli, whose Summa (1494) included arithmetic and doubleentry (Poovey 1998:37).
} 
But Cymbeline combines such "Roman" moments with reminders of contemporary "arithmetic," including calculation of the distance to Milford Haven (3.2.50-74), which, from the higher elevation of a "mountain-top," seems much closer (3.6.4-6). Such moments of "perspective" in Cymbeline are related to assessing "prospects" in multiple senses - surveying a prospect of land or calculating a distance, but also calculating future prospects, including profit or vantage, as Iachimo calculates his prospects before laying his bet in the wager plot.

The new arts of calculation included the plotting of battle formations and surveying of "plots" or plats that connected the theater of war to theater itself (Turner 2006:43-81). Cymbeline combines Roman military terms with anachronistic references to "knights o'th'battle" (5.4.20; Edelman 2000:188, 195-196, 411) and the new military arithmetic that used the "infidel symbols" identified with commerce. "Hazard" (4.4.46), for military risk, recalls the description in English military treatises of Julius Caesar's famous dice throw (Alea iacta, "the die is cast"), used by "Spaniards in the Low Countries" (Edelman 2000:168); but also Shakespeare's Richard III ("I have set my life upon a cast|And I will stand the hazard of the die," 5.4.9-10), a gamble lost to the future Tudor king associated with Milford Haven in Wales.

The rise of military arithmetic was spurred by the Turk, whose soldiers were "the most effective infantry force the world had seen since the days of the Roman legions" (Edelman 2000:369-372), the Ottoman successor to ancient Rome opposed to Hapsburg Charles V as "Holy Roman Emperor." Its other major impetus was military engagement in the Low Countries, where English Protestants sided with Dutch against Spanish, a war pertinent to Cymbeline because Cymbeline's concluding peace with Rome recalls James's peace with Spain. ${ }^{8}$ Though many English gentlemen resisted commercial

\footnotetext{
8 "Impious turbans" (3.3.6) in a scene recalling Augustan Rome (Parker 1989:202) would evoke Constantinople, more than once a "new Rome," and not simply preOttoman Saracens. "Dutchman" and "Spaniard" in the wager scene evoke the Low Countries as both commercial arithmetic and bookkeeping center (whose Antwerp Burse was model for Gresham's London Exchange) and battlefield on which Englishmen fought before and after Antwerp's fall in 1585. Antwerp in Brabant and the Low Countries' wars were earlier recalled in the name-choice Brabantio and echoes of $A$ Larum for London in Othello (including 2.3, where Cassio is "cashier'd").
} 
arithmetic, military strategizing required arithmetic's calculations. The Arithmeticall Militarie Treatise, Named Stratioticos (1579), by the gentlemen Leonard and Thomas Digges, appended "military examples to the usual commercial examples" (Woodbridge 2003:7). ${ }^{9}$ The 1588 Spanish Armada, recalled in Cymbeline's Roman invasion of Britain, led to a new spate of arithmetic books reflecting military and commercial needs (Woodbridge 2003:4-7). ${ }^{10}$ An expanded Stratioticos was published in 1590 by Richard Field, prolific publisher of commercial and military arithmetics (Woodbridge 2003:7), as well as Shakespeare's fellow-Stratfordian and publisher of Venus and Adonis and The Rape of Lucrece. His name is cryptically alluded to in Cymbeline as "Richard du Champ" (4.2.376).

The combination of military with commercial is foregrounded on Cymbeline's multiple fields of battle. In the wager scene, Iachimo pictures Innogen as both military ensign-bearer for Posthumus and underwriter of this "beggar's" inflated value (1.4.14-17). "Arrearages" (2.4.13) of Britain's unpaid "tribute" debt lead to Rome's invasion. Posthumus's detailed narrative account in 5.3, of the battle the audience has just seen, is a recounting of the heroism of "two striplings" and "an ancient soldier, | An honest one, I warrant" (15-19), which becomes a reckoning of numbers against the outnumbered (without mentioning he was the "fourth," 86). The bravery of "These three, | Three thousand confident, in act as many |For three performers are the file when all|The rest do nothing" (5.2.28-31) turns the losing battle other Britons are fleeing into the Romans as "ten chased by one" and Britons as "each one the slaughterman of twenty" (5.3.48-49). But when the British lord who was one of the "fliers" (5.3.2) reduces his detailed account to "A narrow lane, an old man, and two boys!" (5.3.52), Posthumus responds "Will you rhyme upon't, $\mid$ And vent it for a mock'ry? Here is one:|'Two boys, an old man twice a boy, a lane,|Preserved the Britons, was the Romans' bane" (5.3.55-58). His parody of such reductive summing up recalls both folk sayings and the cryptic riddles of commercial arithmetics, just as "vent it for a mockery"

\footnotetext{
${ }^{9}$ Stratioticos has been cited, with other such texts, in relation to Iago's contempt for the "bookish theoric" of Cassio the "arithmetician" in Othello (Edelman 2000:357).

${ }^{10} 1588$ also saw the first English translation of work on artillery by Niccolò Tartaglia (Woodbridge 2003:7), whose career included commercial arithmetic, bookkeeping, and surveying.
} 
(from vendre to sell, as well as publish) expresses contempt that the heroism that defeated the Romans against all odds could be reduced to a commercially exploitable "rhyme."

All of these instances are related to the new "arithmetic" invoked in Cymbeline, including Posthumus's narrative accounting to someone not present. What follows now turns to accounting itself, the Jailer's invocation of "debitor and creditor" bookkeeping (5.3.228-229) and its importance for this play's wager and slander plots, commercial preoccupations, and other accounts, including those provided by Iachimo, culminating in his own extended account in the Recognition Scene.

After Posthumus (longing for death) has changed from "Briton" to "Roman" to be imprisoned and executed, had his dream of his Leonati family, and been unable to decipher the text left by Jupiter, his British Jailer enters:

JAILER Come, sir, are you ready for death?

POSTHUMUS Over-roasted rather; ready long ago.

JAILER Hanging is the word, sir. If you be ready for that, you are well cooked.

PosthumUs So if I prove a good repast to the spectators, the dish pays the shot.

JAILER A heavy reckoning for you, sir. But the comfort is, you shall be called to no more payments, fear no more tavern bills, which are as often the sadness of parting as the procuring of mirth. You come in faint for want of meat, depart reeling with too much drink; sorry that you have paid too much, and sorry that you are paid too much; purse and brain both empty: the brain the heavier for being too light, the purse too light, being drawn of heaviness. Of this contradiction you shall now be quit. O the charity of a penny cord! It sums up thousands in a trice. You have no true debitor and creditor but it: of what's past, is, and to come, the discharge. Your neck, sir, is pen, book, and counters; so the acquittance follows. (5.3.214-230)

The Jailer invokes "counters" together with the "book" of "debitor and creditor" and arithmetic of the "pen," able, like the hangman's rope, to "sum up thousands in a trice," in an exchange filled with the commercial, legal, and biblical language of credit, debt, and "acquittance." Its biblical echoes include the lex talionis and 
"measure" (Matthew 7:2) that provided the title of Measure for Measure; the forgiveness of debts or trespasses; Redemption from an unpayable debt; and the final Reckoning, Last Judgment, or Audit. ${ }^{11}$ Its equivoques include "acquittance" as discharging a debt to usurious creditors and the debt/death owed to God; "reckoning" as "paying a tavern bill" and "making an atonement"; Posthumus's body as a "dish" that "pays the shot" or bill and a meal worth its price. "Sorry that you have paid too much, and sorry that you are paid too much" includes (a) "have paid" as depleted of ready cash or coins and (b) "are paid" as "paid" back (4.2.245), evocative of Cymbeline's plots of revenge as "payback."

At the same time, the Jailer's language foregrounds the sexual, bodily and monetary associated with "arithmetic" and "accounts" of "debitor and creditor." "Purse too light, being drawn of heaviness" suggests both "emptied (of the coins) that made it weighty" (Butler 2005:223); and the empty bodily "purse" of the impotent "fool" Cloten (4.2.112), who may have been played by the same actor. "Heavy" and "light" recalls the biblical burden that is paradoxically "light" but also the "light" women and heavy "purse" of sexual commerce. The repeated sound of " $\mathrm{O}$ " leading to "sums up thousands in a trice. You have no true debitor and creditor but it" evokes the female "O," sexual arithmetic's "infidel" cipher. ${ }^{12}$ But it also suggests (in "true") that if the female "count" is suspect as "untrue" (as Posthumus assumes of Innogen's "wrying"), no earthly accounting or perspective, including his, is reliably "true" either.

The combination of "debitor and creditor" with unpaid "debt" makes this British prison symbolically a debtor's prison, in ways that resonate within Cymbeline. Its pervasive references to prisons, locks, and "manacles" evoke not only usurious creditors but also debtor's prisons, including the "Counter" in Southwark exploited in bawdy contemporary wordplay on bodily "counts," "accounts," and the

\footnotetext{
${ }^{11}$ See Parker (1996:56-82; 2009:228-233) on these biblical-financial terms, including "redemption"; Matthew (18:21-35; 25:14-30: Parable of the Talents and "faithful steward"), central to debates over usury, interest or "vantage" (Hawkes 2010:83-93); Luke 6:35; Woodbridge (2010:89-93) on owing God a death, Christ's paying an unpayable debt, and "forgive us our debts" (Matthew 6:12).
}

${ }^{12}$ I agree with Nosworthy (1955:162) on not emending the first Folio "Oh" to "Of." 
"counters" used for reckoning unpaid bills. ${ }^{13}$ The Jailer's speech echoes the Henriad's tavern scenes and Falstaff's debts to the "Hostess" both financial and sexual, debts he promises to pay but continues to put off, like the "debt" he owes to "death" (1Henry IV 5.1.126). But Posthumus has cast himself into this prison, a "bondage" (5.3.97) he desires to escape not by evasion but by the "death" he reckons he owes as payback ("measure for measure") for Innogen's murder. Hastening into death ironically recalls the other consummations he devoutly and undevoutly wished, including the one he thinks has already been accomplished because of the "bloody cloth" (5.1.1). ${ }^{14}$ Echoes of the "debt" put off by Falstaff, while "death" (its homophone) is eagerly sought by this still impetuous young man, suggest that "redeeming the time" (Ephesians 5:16) is badly served by both extremes.

This scene "foreshadows the turn toward comedy" and the "new perspective" to come, including hints in "Posthumus's more transcendental replies" of the "play's hidden awareness of the 'fact' that Christ was born in Cymbeline's reign" (Butler 2005:222). Cymbeline's combination of commercial, martial, and societal/ personal "bonds" includes multiple (false and true) promises, appraisals of what outwardly appears promising or unpromising, and the "promissory" language of assumpsit or a promise to pay (Muldrew 1998:207). But it also foregrounds promises not kept or fulfilled, or not yet accomplished, including biblical ones. By the end of act 5 , retaliation's payback is replaced by forgiveness. But the promised biblical redemption is not yet come. Even the "tribute" to Rome, the "debt" whose "arrearages" led to war, is still not paid by play's end: Cymbeline is only "promising to pay" it (5.4.459). ${ }^{15}$

\footnotetext{
${ }^{13}$ On the "manacle" or bracelet Posthumus puts on Innogen in 1.1, see Wayne (2002:288-315). Cymbeline reworks the "bonds" of The Merchant of Venice into a "credit crisis" involving this and other objects; with bonds not just as contracts, personal pledges or tokens but as a desire to "bind" (or "manacle") inseparable from fear that binding can be "loosed."

${ }^{14}$ In 5.3.1-123, he asks the "gods" (who "coined" him) to take "all" in death's final "audit," and "cancel these cold bonds," unlike creditors who "thrive" by reprieving "broken debtors" (5.3.112-115). "Consummation" is used for death in 4.2.279 and punned on with sexual consummation in Hamlet 3.1.62.

15 See also 4.2.338; 4.3.38; 4.4.28; 5.3.200; 5.4.9; 5.4.458. Cymbeline's "promissory" language includes the debt de mariage and infidelity as contractual breach of promise
} 
The exchange between Posthumus and his Jailer raises issues that are still open-ended by the end of the play, including "transcendental" ones. But it also foregrounds (in "no true debitor and creditor but it") the issue of the truth claims of double-entry itself and the problem of "credit," belief and trust, in Cymbeline as a whole. ${ }^{16}$ The ars notaria of "pen" and "ink" arithmetic, and writing of letters with which Cymbeline is filled, included "debitor and creditor" bookkeeping as a written accounting required by the "sedentary merchant" to assure the "fidelity, honesty, and truth" of his "lieutenants" (Crosby 1997:205), "agents" or "factors." It also reflected the rise of business partnerships (like the one Iachimo pretends to be "factor" for), and the need to calculate not only the profits of the company as a whole but which partners were owed what (De Roover 1974:121-128; Robson 1992:694-704).

"Debitor and creditor" accounting, from the Florentine ledger or libro dei debitori e creditori (De Roover 1974:143), was disseminated in its Venetian facing-pages form through Luca Pacioli's Summa de arithmetica, geometria, proportioni et proportionalità (Venice 1494). In Antwerp, Jan Ympyn Christoffels's redaction was translated into French and then English, as How to Kepe a Boke of Accomptes (1547). ${ }^{17}$ In England, James Peele (father of dramatist George Peele) produced How to Keepe a Perfect Reconyng after the order of the moste worthie and notable accompte, of Debitour and Creditour (1553), expanded in The Pathe waye to Perfectnes, in th'Accomptes of Debitour, and Creditour (1569). John Mellis's Briefe Instruction and Maner how to Keepe Bookes of Accompts after the order of Debitor and Creditor (1588) revised the earliest English version of Pacioli, Hugh Oldcastle's A Profitable Treatyce... of the Kepyng of the Famouse Reconynge Called... in Englysshe, Debitor and Creditor (now lost). And other English "Debitor

(5.4.207). "Forbearance" (2.5.10), used by Posthumus for this "debt," was the term not only for patience or holding back but for a creditor's "forbearance" (going without immediate payment). See Parker (2004:26-49) on "forbearance," "promise," "credit," "debt," and the "time" of romance travail before ultimate "return" in The Winter's Tale, a nexus Cymbeline shares in multiple ways.

${ }^{16}$ On "credit" (from credere) as including "trust," see Muldrew (1998: chapter 7).

${ }^{17}$ Nicolaus Petri's Dutch Practique Om te Leeren Reekenen en cypheren (1583) combined "debitor and creditor" with arithmetic; Simon Stevin began as an Antwerp "bookkeeper," wrote a double-entry treatise, and applied arithmetic to military uses (Murray 1978:213). See Parker (2009: 228-235). 
and Creditor" treatises followed, including ones that promoted the new "arithmetic" (Sullivan 2002:13).

The impact of arithmetic's "cipher" was not only as a "numeral in the arithmetic of money" but as "the principle of zero balance in the double-entry book-keeping that controlled the expanding market of credit, debt, and commodities engendered by mercantile capitalism."18 The "central role occupied by double-entry bookkeeping" and its "zero balance" contributed to breaking down resistance to arithmetic's "infidel $\mathrm{O}^{\prime}$ in Europe (Rotman 1987:7). In England, however, Roman numerals continued to be used with "infidel symbols" in account ledgers, just as "counters" and "tally sticks" (for reckoning the "score") appear with double-entry's "books" in Shakespeare. ${ }^{19}$ Henry VI Part 2 invokes a past that "had no other books but the score and the tally" (4.7.35). But "debitor and creditor" bookkeeping and "arithmetic" were increasingly central to England's "culture of credit." The theater district was a center of reckoning schools and accountants who taught arithmetic with double-entry. Humphrey Baker, whose "arithmetic" book The Wellspring of Sciences (1574) was frequently reprinted, "plastered the district" with his promotional "bills," including a 1590 broadsheet advertising his teaching of "debitor and creditor" accounting with "Arithmetike vulgar" and "international currency exchange" (Woodbridge 2010:65-67).

In ways suggestive for Cymbeline, Baker's 1590 broadsheet also advertised surveying (or "How to measure") "Landes, Woods, and all other platformes whatsoeuer" and how to "rectifie, and make perfect any difficult or intricate account, depending in variance between two, or more partners, and thereby to shewe, which of them shall be indebted the one to the other." Its "account of foure Partners, to be rectified and made perfect by the order of Debitor and Creditor" included "Foure Merchants entred into Partnership, that is to say, A.B.C. and D. with this condition following: that all four

\footnotetext{
18 Money required "a system of writing, which included book-keeping and calculation, to enable it to function as an international medium of exchange" (Rotman 1987:78).

${ }^{19}$ There were also fears that arithmetic's "Arabic figures could more easily be forged" than Roman numerals (Thomas 1987:120), including the "O" that could fraudulently multiply by strategic insertion (Kaplan 2000:102). See Parker (2009:236-238); Aho (2005:28ff.).
} 
Should keepe account of their dooings in companie." Baker, like others in England, thus provided arithmetical "accounting" solutions to commercial problems similar to those that led to doubleentry in Italy, including how to reckon credits and debts in partnership situations.

Double-entry treatises stressed the accountant's "scrupulous fidelity to his own word" and procedures to guarantee the account's honesty and credibility or "credit" (Sullivan 2002:28, 40, 155). Pacioli's instruction to put the "name of Jesus" or "sign of the Cross" at the account's beginning - as a pledge of "trust and fidelity" as well as the "good credit" of an "unblemished reputation" (Aho 1985:29) - was repeated in Ympyn and reflected in English doubleentry treatises, including in Mellis's emphasis on "Fidelitie," "Fayth," "honesty," and "truth" (Mellis 1588:10; Poovey 1998:41). However, though it invoked the "fidelity" of the biblical "faithful steward" (Murray 1978:190, 205), double-entry's "impression of honesty" could be only a "show of religiosity" (Aho 1985:32, 29). Though its "formal precision" made it "seem accurate" (Poovey 1998:56), "double-entry bookkeeping guaranteed clarity but not honesty" (Crosby 1997:208). The "ledger was open for all to see," yielding a "fiction of total disclosure" that promised to make it possible to "see and know"; but "the inventory and the journal were secret books" and the "zero balance" was a self-enabling "fiction" (Poovey 1998:58-64). As Kaplan comments (2000:110): "the idea was simple: tote up your credits and debits on the same page of your trading account's ledger, in parallel columns. If the difference between them is zero, your books are balanced, showing your accounts were accurately kept (or skillfully cooked)."

Like the "infidel $O$," the suspect honesty of "debitor and creditor" accounting was linked to the female "count" and double entendres on "account books" (Parker 2009:231). Though doubleentry ensured that "no one else had access to the family treasure," the ledger, its "most public book," claimed to open the private to the

\footnotetext{
20 See Parker (2009:235-238). "Debitor and creditor" was thus linked to the cross complexly evoked in Pisanio's (false) "bloody sign" (3.4.124), which recalls both the bloody red cross ensign of Christ's death and resurrection and Redcrosse knight (whose erring, impulsivity, and desire for death is echoed in Posthumus's), from Book 1 of Spenser's Faerie Queene, where despair's cure includes Fidelia. See also Maley (2008:128) on the crosses of St. George and St. Andrews.
} 
eye's inspection (Poovey 1998:34-35). "PUBLIC LEDGER" was slang for "prostitute because like that paper she is open to all parties" (Williams 1994:1.131-132). Shakespeare's Sonnet 136 combined "account" with "a treasure," a "thing" of "great receipt," a "nothing," and a female "will," while "lenders' books" were juxtaposed with "brothels" and "plackets" in King Lear (3.4.95-8). In Much Ado About Nothing, "I see, lady, the gentleman is not in your books" (1.1.79) suggests "account books of a tradesman in which creditable customers were listed" (McEachern 2006:154). But its slander plot, like Cymbeline's, ultimately exposes the dishonesty of the slanderer's "accounts."

The impression of fidelity and truth created by "debitor and creditor" accounting is crucial for this play, where Iachimo's "inventory" and untrue "story" of his night in Innogen's "chamber" (2.2.27-30;2.4) provides "simular proof enough" (5.4.200) to Posthumus that Innogen is untrue. The fact that an accountant could appear honest, when an account was forged, is crucial to the wager plot. But concern that there is "no true debitor and creditor" accounting provides an important context for multiple accounts and truth claims in this play, including other slanderous accounts that affect the "good credit" of an "unblemished reputation."22 "Counterfeiting" (applied by Posthumus to the female "count," coining "counterfeit" or bastard issue with some "coiner," 2.5.5-6) characterizes Iachimo's account. But it also extends to the larger problem of "simular proof," in this play filled with false or wrongly deciphered "signs," as well as simulacra and doubles, including the commercial and biblical as potential lookalikes.

Cymbeline's central slander plot begins in the wager scene in Rome, where "country matters" sound in the praise of "our country mistresses" (1.4.45-46); and men from different countries evoke the Europe whose differences of measurement, coinage, and valuation led to the need for arithmetic as well as "debitor and creditor"

\footnotetext{
${ }^{21}$ Iachimo also slanderously reports the turned-down "leaf" of Ovid's Metamorphoses where "Philomel gave up" (2.2.45-46), recalling the "two-leaved book" as "a woman opening to receive a man" in Ovid's Amores III.xiii (Williams 1994:1.131-132).

22 This includes Belarius (3.3); and Pisanio (4.2.311-328), assumed by Innogen to be a murderer and counterfeiter of "forgèd letters." Cymbeline also foregrounds the competing truth claims of different historical accounts (Floyd-Wilson 2003:166-180; Kerrigan 2008:115ff.).
} 
accounting. The scene begins with news accounts from Britain, as the men use differing assessments to weigh up the newly-arrived Briton. Iachimo finds him wanting, invoking the inventorial language of his appraisal on an earlier occasion: "I could have looked on him without the help of admiration, though the catalogue of his endowments had been tabled by his side, and I to peruse him by items" (1.4.3-5).

The language of price, prize, praise, and appraise familiar from The Merchant of Venice pervades the fidelity-wager that ensues. Posthumus, already given to zero-sum games like dueling (in ways that make fighter-gambler Cloten his double), not only assents to the wager. He pledges Innogen's gift to him of her mother's "ring" (sign, like the bracelet, of the female "O," but also of his promise to be "true"), which Iachimo reappraises as the "trifle" she's "outprized by" (1.4.65). Sizing up Posthumus in this high-stakes gamble, Iachimo not only calculates the amount worth risking, on the odds that he will win (10,000 ducats, much more than Shylock's 3,000), but what it would take to provide "sufficient testimony" (1.4.121) to this impulsive Briton that he has "enjoyed" the "dearest bodily part" of his "mistress" (1.4.122). This may also contribute to his decision in 2.2 not to rape Innogen, but to make away quickly with what he calculates would for Posthumus be "simular proof enough" (5.4.200).

In his mercantile "voyage upon" Britain to pursue his "advantage" (1.4.104, 128), Iachimo cynically exploits the Parable of the Talents (1.6.78-82) used to justify usury, profit, or "vantage." He reports that the "gamesome" Posthumus has been using Innogen ("which I account his") as his personal cash account, "coffers" or "purse," 23 while "partnered" with "diseased ventures" (prostitutes and gambling risks). He urges her to "be revenged" by taking him as

\footnotetext{
23 The marriage chests or cassone important for Cymbeline 2.2 (Butler 2005:31) were already combined with double-entry's "cash" account (Pacioli's cassa or account of the "Chest, or purse" as "ready money," Mellis 1588:C2r,D4iiir) in the casket/chest linked to the "rich prize," "price," or treasure of Portia in The Merchant of Venice (Jaffe 1999:66-84). This "cash account" as a "secret" case or chest was associated with the female "count" or "case" (Parker 2009:230-232; OED cash n. 1; case n. 2), whose sexual sense Cloten's desire to "understand" Innogen's "case" makes explicit (2.3.70). On the case/casket/female "treasure"/trunk, see also Parker (1987:134-138); with Pichter (2005:152-154) on "trunk," "chest," and Boccaccio's cassa; Belsey (1999:55-62) on the marriage chest; Parker (2009:230-231) on John Florio's cassa, chest, casso, cashier, Cassio, and Ben Jonson's "Cash."
} 
her lover (1.6.78-139). But when she refuses to "credit" his "false report" (a term used in this scene for belief as well as fidelity and trust) and calls for help to expose this "saucy stranger" come to "mart $\mid$ As in a Romish stew" (150-152), he assures her that he "adventured" this untrue account only to test her (172-173). Shifting strategy, he poses as "factor" for a business partnership ("Myself and other noble friends | Are partners in the business," 1.6.183-184), who needs "safe stowage" (192) for its valuables: "Some dozen Romans of us and your lord $\mid[\ldots]$ have mingled sums $\mid$ To buy a present for the Emperor,|Which I, the factor for the rest, have done|In France" (185-188). His stratagem for gaining access to her "chamber" (as he will that night in the "trunk" he claims contains this "present") is thus a "business" in which Innogen has a double-meaning "interest" (1.6.195), the term used earlier for the bond with Posthumus in which she is creditor as well as debtor (1.3.30).

The scene's commercial language ("material," "tender," "promise," "short my word," "length'ning my return," "truly yielded") includes the unsuspecting Innogen's willingness to "pawn" her own "honour" (1.6.194) to protect the property of a company of which her "lord" is partner. Even before the "moveables" of her "chamber" become part of the "inventory" and "story" retailed by this dishonest "factor" (2.2.27-30), it is an "honour" in which Posthumus has a double stake (sexual and "material"), because of the contracted wager. In this play where seeming opposites become mirrors or doubles for one another, Iachimo's untrue account of a partnership simultaneously reflects a truth about Posthumus his opponent/partner. "Partners" evokes business partnerships like those bound up with arithmetic and double-entry bookkeeping in Baker and others, including the combination of competing and common interests the new arts of calculation were designed to manage. At the same time, it recalls the homosocial rivalry-emulation of the wager scene, a company of men praising/ appraising their "country mistresses," with the risk of opening private property to theft.

Cymbeline's wager plot strikingly evokes "debitor and creditor" accounting and arithmetic again in act 2. In 2.2, Iachimo substitutes his "inventory" for rape. And in 2.4, he invokes the "circumstances" central to double-entry's claim to honest accounting. "Circumstances" were the "interrogatory questions" Pacioli took 
from Roman rhetoric's technique for amplifying a discourse, which were also used in "the confessional interrogation of the penitent" (Aho 1985:26): "quis (who), quid (what), quare (where), quando (when), quantum (how many), cum quo (in whose presence), and cur (how)." Double-entry thus brought together the "business account" and "confessional account" in ways reflective of Pacioli's training in rhetoric but also in a "Franciscan monastery where weekly confession was the rule" (Aho 1985:26). English double-entry treatises likewise stressed the importance of these "circumstances" or answers to "interrogatories," crucial to judicial examination and proof (Parker 2009:234-235). ${ }^{24}$

That the "interrogatories" and "circumstances" essential to a narrative account were required in "debitor and creditor" accounting is important for Cymbeline as whole. It opens with accounts of offstage events and repeatedly foregrounds demands for detailed reports by characters not present themselves. Demands for a full and complete account (or narrative recounting) range from Innogen's questioning of Pisanio to Cymbeline's more inquisitional demands, under threat of torture if his interrogatories are not completely and honestly "answered." But this play is also filled with "counterfeit" or false accounts, as well as accounts that are deceptively partial (in both senses), including Belarius's "story" to the "sons" who think he is their father (3.3.44-78). Even Belarius's first account in the final Recognition Scene is both partial and untrue (5.4.16-19). ${ }^{25}$

Iachimo's account to Posthumus of his night in Innogen's "chamber" begins with the promise of the faithful "debitor and creditor" accountant: "my circumstances|Being so near the truth as I

\footnotetext{
${ }^{24}$ See also Parker (1996:354-355); Poovey (1998:37-58) on double-entry's "balance," designed to resemble divine order, symmetry, and rectitude as well as the scales of justice; Jaffe (1999:66) on its use of purgatio for "reconciling the books," suggestive for Cymbeline as tragicomic romance since "purgation" involved examination, trial, and contrition before "reconciliation"; and Parker (2009:235) for work on double-entry's "power-knowledge apparatus" as a "practice of inquisitio." See Cymbeline 4.3.12; 4.4.14; 5.4.133-139 for demands to render an account under threat of "torture;" or "death" (3.5.80-98); and 4.2.360-366, where the "circumstances" are evoked in Lucius's questions to Fidele. See also Meek (2009:194). On inventory and "invention," see Parker (1987:136) and Aho (2005:63ff.).

25 Even Innogen as faithful "Fidele" creates untrue stories while being "true" to Posthumus (eg. 4.2.376-378), a variation of Pisanio's "Where I am false, I am honest; not true, to be true" (4·3.42). See also Betteridge (2013:234-235).
} 
will make them,| Must first induce you to believe" (2.4.61-63). But "make" suggests something forged, even as he claims his "circumstances" need no confirming "oath" (65). The evidentiary circumstances compiled by this "factor" include what he "writes" down or "notes" in his "inventory" (2.2. 24-30). But he also stores in the accountant's Memorandum Book of his own memory some "natural notes about her body" (2.2.28), including the "mole" (38) crucial in 2.4, where the circumstances of his "story" and narrative recounting prove essential. The sight of the "manacle" or bracelet is not enough without Iachimo's false account of how Innogen took it off (2.4.95-106; Wayne 2002:288-295). And Posthumus does not finally credit Iachimo until his story refigures her innocent "mole," not as a "natural" mark or "note" but as a double-meaning "stain" (2.4.135-139). ${ }^{26}$ This then quickly becomes, in Posthumus's rapid reckoning, the assumed infidel " $\mathrm{O}$ " as a bodily stain as large as "hell can hold" (140), mistakenly deciphered sign that his private "account" has become an "open book."

The cassa, "case," or unlocked "treasure" (2.2.42) at stake for Posthumus is the female "count" that sounds not only in "Spare your arithmetic; never count the turns" (2.4.142) but in what Innogen should "from encounter guard" (2.5.19), as Posthumus visualizes Iachimo as a lusty German "boar" penetrating it with a cry of "Oh!" (2.5.16-17). ${ }^{27}$ Iachimo is already Cymbeline's Iago: but in Posthumus's jealous-voyeuristic imagining of him taking his "place" in Innogen's "bed" (5.4.185), he becomes its "lieutenant" Cassio as well. ${ }^{28}$ Posthumus's conclusion that the "woman's part" (2.5.20) is unfaithful, and he himself is a "counterfeit" coined by some "coiner" $(2.5 \cdot 5-6)$, is an ironic reminder that the currency of the wager plot itself is counterfeit coin. And the forgery depends on Posthumus's own coining of "simular proof" in the forge of his imagination, becoming Iachimo's partner in this as well.

\footnotetext{
${ }^{26}$ That seeing is impacted by Iachimo's narrative telling is clear when the same bodily "mark" or "stamp" on Guiderius is viewed through a different cultural lens in 5.4.363373. See also Lyne (2013:59).

27 See Lyne (2011:156). On "German"/"Geminus," double or twin, see Parker (1987:69-77; 1996:127-131).

${ }^{28}$ On "lieu-tenant" in the sexual sense, see Parker (1996:246).
} 
In the final Recognition Scene of Cymbeline, the "circumstances" of a complete accounting are invoked yet again. Cymbeline's "When shall I hear all through? This fierce abridgement|Hath to it circumstantial branches" (5.4.388-389), combines the detailed narrative ramifications of too short an account with the "branches" of his own genealogical tree. His "Where, how [...] when [...] how [...] whither" and other questions to be "demanded," once again invoke the "interrogatories" of "debitor and creditor," something that in the "abridgement" of dramatic "show" there is not time to "tell": "But nor the time nor place|Will serve our long inter'gatories" (5.4.392-393).

Before this, Iachimo's amplified narrative "circumstances" produce the longest account in the entire play. Under Cymbeline's threat of "torture" if he does not tell the truth (5.4.133), Iachimo tortures the King himself by repeatedly breaking off, while claiming his reluctance to get to the point because his revelations would "torture" his hearer (140). His account is staged as if it were a "confession." But it is risky to take Iachimo's consummate performance at face value, as reliable coin. Once again, he manipulates the power of circumstantial evidentia or enargeia (Parker 1987:138-140; 1996:242-245), voyeuristically picturing events for those who were not there. His "confessional" account simultaneously exploits rhetoric's potential for the counterfeit or "simular," through ambiguous inferences about what cannot be seen (or known) about the details his account includes, or about the accountant himself beyond his own controlled "show." Paradoxically, what appears to be the fullest account in the play, in response to the demand for a complete and honest accounting, is deceptively partial, putting on display his continuing ability to appraise or calculate what to picture to (and withhold from) a particular audience.

Cymbeline's biblical echoes provide reminders that the ultimate Recognition Scene of Revelation or Apocalypse is only "foreshadowed," a "promise" not yet accomplished and "redemption" still to come. The foregrounding within it of the difficulty of "distinction" or "partition" (1.6.37), amidst proliferating simulacra and doubles, underscores that the definitive separation of "counterfeit" from "true" awaits that ultimate Revelation or unmasking, where the Luciferic lookalike (and dissimulating 
accountant) will be replaced by the Redeemer called "Faithful and True" (Revelation 19:11). ${ }^{29}$ By Cymbeline's end, however, even the New Testament Epiphany is still in the future, awaiting a Nativity that has not yet occurred. In the play itself, there is no final (or "true") "debitor and creditor," Audit, or Reckoning, and no perfect "Faithful and True." 30 Even "Fidele" is revealed as Innogen, at the same time as "play" and "part" (5.4.228-229) call attention to the playing of her "woman's part" by a boy actor, in a transvestite English theater that itself dissimulates and simulates, requiring the audience to see double, boy player and female character restored.

Cymbeline foregrounds the problem of uncertain "knowledge" (1.1.6o) and cognitive impenetrability (Spolsky 2004:72-79), but also the perils of interpretive certainty. Its echoes of 1 Corinthians 13 (where knowing is only "in part" and seeing is per speculum in aenigmate, through an enigmatic mirror or "glass darkly") provide a wrying perspective on the play's own enigmas and decipherings. The Roman "Soothsayer" Philharmonus, official decipherer of enigmatic signs, may be a reliable "sooth" (or truth)-sayer; or, from another perspective, an imperial spin-meister, able to adapt his answers to the new prospects and "circumstances" of changing times.

In the more contemporary context of "sooth"-saying evoked by the Jailer's "no true debitor and creditor but it," double-entry accounting was a "vehicle for producing public knowledge - that is, knowledge that was designed to function in public as a sign of something more than the information included in the books" (Poovey 1998:37). Its own claims to certain knowledge, as well as truth-telling, depended in its final ledger or "book" on numbers that

\footnotetext{
${ }^{29}$ See Parker $(1996: 56-82,367)$ on biblical lookalikes, counterfeits, and simulacra in The Comedy of Errors, including the "devil" disguised as "angel of light" (2 Corinthians 11:14) also exploited in Othello (2.3.351-352; 1.3.16-19); Parker (2009:238).

${ }^{30}$ In Book I of Spenser's Faerie Queene, the period of romance "error" is the time before this final Revelation and knight "Faithful and True." Cymbeline's setting "pre" the birth of Christ is also relevant to a critique of empire, since the imperial Rome and Augustan pax emulated by James were surpassed by the Rome that could not be seen. Reminders in Jupiter's descending eagle of the rape of Trojan Ganymede (cause of Juno's revenge on Troy's descendants) also complicate more straightforward praise of James; and need to be added to the other ways this play ironizes Jupiter as well as James, cited, inter alia in Palfrey (1997:243-250); Maley (2003:31-44; 2008:119-137); King (2007:92-95). On the Soothsayer, see Throne (1999:189); Betteridge 2013:236).
} 
purported to provide evidence of things in themselves (Poovey 1998:64). Its borrowings from an older religious language confessional "interrogatories" and purgatio for the reconciling of its "books" - may have given this system of knowledge production the "credit" to which it aspired. But even in the commercial "culture of credit" that was Shakespeare's contemporary context, there were skeptical voices and fears that its claims to honesty and certain knowledge were susceptible to simulation and fraud. Cymbeline provides crucial reminders that "evidence" is inseparable from evidentia, the rhetorically counterfeited illusion of definitive proof, just as double-entry itself as warrant of truth was based on its own fictions, forging the appearance of accounts that could be trusted.

The importance of "arithmetic" and "debitor and creditor" accounting is thus not restricted to the scenes in Cymbeline in which they are invoked by name. Rather, both are central to the language and preoccupations of this combination of "Roman," romance, and "bourgeois" plot.

\section{References}

Aho, James 1985. "Rhetoric and the Invention of Double-Entry Bookkeeping." Rhetorica 3/1:21-43.

2005. Confession and Bookkeeping. Albany: State University of New York Press.

Bady, David 1985. "The Sum of Something: Arithmetic in The Merchant of Venice." Shakespeare Quarterly 36/1:10-30.

Baker, Humphrey 1574. The Wellspring of Sciences. London.

ca. 1590. "Such as are desirous, either themselves to learn, or to have their children or servants instructed in any of these arts and faculties here under named, it may please them to repair unto the house of Humphry Baker." London: Thomas Purfoot [?]. STC 1209.3. Broadsheet.

Belsey, Catherine 1999. Shakespeare and the Loss of Eden. New Brunswick: Rutgers University Press.

Bernstein, Peter L. 1996. Against the Gods: The Remarkable Story of Risk. New York: John Wiley \& Sons.

Betteridge, Thomas 2013. "Writing faithfully in a post-confessional world." Eds. Andrew J. Power and Rory Loughnane. Late Shakespeare, 1608-1613. Cambridge: Cambridge University Press: 225-242. 
Blank, Paula 2006. Shakespeare and the Mismeasure of Renaissance Man. Ithaca: Cornell University Press.

Boyer, Carl B. 1968. A History of Mathematics, second ed. rev. Uta C. Merzback. New York: John Wiley \& Sons.

Butler, Martin 2005. Ed. Cymbeline. Cambridge: Cambridge University Press.

Crosby, Alfred W. 1997. The Measure of Reality: Quantification and Western Society, 1250-1600. Cambridge: Cambridge University Press.

Digges, Leonard and Thomas 1579. An Arithmeticall Militarie Treatise, Named Stratioticos. London.

Digges, Thomas 1590. An Arithmetical Warlike Treatise Named Stratioticos. London.

De Roover, Raymond 1974. Business, Banking, and Economic Thought in Late Medieval and Early Modern Europe. Ed. Julius Kirshner. Chicago: University of Chicago Press.

Edelman, Charles. 2000. Shakespeare's Military Language: a dictionary. The Athlone Press.

Evans, G. Blakemore and J.J.M. Tobin. eds. 1997. The Riverside Shakespeare. Second Edition. Boston: Houghton Mifflin.

Fischer, Sandra K. 1985. Econolingua: A Glossary of Coins and Economic Language in Renaissance Drama. London: Associated University Presses.

Floyd-Wilson, Mary 2003. English Ethnicity and Race in Early Modern Drama. Cambridge: Cambridge University Press.

Gillen, Katherine 2011. "Chaste Treasure: Protestant Chastity and the Creation of a National Economic Sphere in The Rape of Lucrece and Cymbeline." Early English Studies 4: 1-38.

Glimp, David, and Michelle Warren, eds. 2004. Arts of Calculation: Numerical Thought in Early Modern Europe. New York: Palgrave Macmillan.

Hadden, Richard W. 1994. On the Shoulders of Merchants: Exchange and the Mathematical Conception of Nature in Early Modern England. Albany: State University of New York Press.

Hawkes, David 2010. The Culture of Usury in Renaissance England. New York: Palgrave Macmillan.

Jaffe, Michele Sharon 1999. The Story of O: Prostitutes and Other Good-for Nothings in the Renaissance. Cambridge: Harvard University Press.

Kaplan, Robert 2000. The Nothing that Is: A Natural History of Zero. Oxford: Oxford University Press.

Kerrigan, John 2008. Archipelagic English. Oxford: Oxford University Press. 
King, Ros 2007. "In Lieu of Democracy, or How Not to Lose Your Head: Theatre and Authority in Renaissance England." Eds. Subha Mukerji and Raphael Lyne. Early Modern Tragicomedy. Cambridge: D. S. Brewer: 84-100.

Korda, Natasha 2009. "Dame Usury: Gender, Credit and (Ac)counting in the Sonnets and The Merchant of Venice." Shakespeare Quarterly 60/2: 129-153.

Lyne, Raphael 2011. Shakespeare, Rhetoric, and Cognition. Cambridge: Cambridge University Press.

2013. "Cymbeline: Recognition in Cymbeline." Eds. Andrew J. Power and Rory Loughnane. Late Shakespeare, 1608-1613. Cambridge: Cambridge University Press: 56-70.

Maley, Willy 2003. Nation, State, and Empire in English Renaissance Literature. New York: Palgrave Macmillan.

2008. "Cymbeline, the Font of History, and the Matter of Britain: From Times New Roman to Italic Type." Ed. Diana E. Henderson. Alternative Shakespeares 3. New York: Routledge: 119-137.

McEachern, Claire 2006. Ed. Much Ado About Nothing. London: Thomson Learning.

Meek, Richard 2009. Narrating the Visual in Shakespeare. Farnham: Ashgate.

Mellis, John 1588. A Briefe Instruction and maner how to keepe bookes of Accompts after the order of Debitor and Creditor. London.

Menninger, Karl 1969. Number Words and Number Symbols. Cambridge, Mass.: The M.I.T. Press.

Muldrew, Craig 1998. The Economy of Obligation: The Culture of Credit and Social Relations in Early Modern England. London: Macmillan.

Murray, David 1978. Chapters in the History of Bookkeeping, Accountancy, $\mathcal{E}$ Commercial Arithmetic. New York: Narno Press.

Nosworthy, J. M. 1955. Ed. Cymbeline. London: Methuen.

Pacioli, Luca 1494. Summa de arithmetica, geometria, proportioni et proportionalità. Venice.

Palfrey, Simon 1997. Late Shakespeare: A New World of Words. Oxford: Oxford University Press.

Parker, Patricia 1987. Literary Fat Ladies: Rhetoric, Gender, Property. London: Methuen.

1989. "Romance and Empire: Anachronistic Cymbeline." Eds. George M. Logan and Gordon Teskey. Unfolded Tales. Ithaca, Cornell University Press: $189-207$. Press. 
2004. "Temporal Gestation, Legal Contracts, and the Promissory Economies of The Winter's Tale." Eds. Margaret W. Ferguson and Nancy E. Wright. Women, Property, and the Letters of the Law. Toronto: University of Toronto Press: 25-49.

2009. "Cassio, Cash, and the 'Infidel o': Arithmetic, Double-entry Bookkeeping, and Othello's Unfaithful Accounts." Ed. Jyotsna G. Singh. A Companion to the Global Renaissance. Oxford: Wiley-Blackwell: 223-241.

Parolin, Peter A. 2002. "Anachronistic Italy: cultural alliances and national identity in Cymbeline." Shakespeare Studies 30: 188-215.

Peele, James 1553. The maner and fourme how to kepe a perfecte reconyng, after the order of the moste worthie and notable accompte, of Debitour and Creditour. London.

1569. The Pathe waye to Perfectnes, in th'Accomptes of Debitour, and Creditour. London.

Pitcher, John 2005. Ed. Cymbeline. London: Penguin Books Ltd.

Poovey, Mary 1998. A History of the Modern Fact: Problems of Knowledge in the Sciences of Wealth and Society. Chicago: The University of Chicago Press.

Raman, Shankar 2008. "Death by Numbers: Counting and Accounting in The Winter's Tale." Ed. Diana E. Henderson. Alternative Shakespeares 3. New York: Routledge: 158-180.

- 2010. "Specifying Unknown Things: The Algebra of The Merchant of Venice." New York: Routledge: 212-231.

Recorde, Robert 1543. The Ground of Artes. Teachyng the worke and practise of Arithmetike. London.

Robson, Keith 1992. "Accounting Numbers as 'Inscription': Action at a Distance and the Development of Accounting." Accounting, Organizations and Society 17/7: 685-708.

Rotman, Brian 1987. Signifying Nothing: The Semiotics of Zero. New York: St. Martin's Press.

Ryner, Bradley D. 2008. "The Panoramic View in Mercantile Thought: Or, A Merchant's Map of Cymbeline." Eds. Barbara Sebek and Stephen Deng. Global Traffic: Discourses and Practices of Trade in English Literature and Culture from 1550 to 1700 . New York: Palgrave Macmillan: 77-94.

Seife, Charles 200o. Zero: The Biography of a Dangerous Idea. New York: Penguin.

Siemon, James R. 1994. "Perplexed beyond self-explication': Cymbeline and early modern/postmodern Europe." Eds. Michael Hattaway, Boika Sokolova and Derek Roper. Shakespeare and the New Europe. London: T\&T Clark: 294-309. 
(c) ederi 23 (2013)

Spolsky, Ellen 2004. "Women's Work is Chastity: Lucretia, Cymbeline, and Cognitive Impenetrability. Eds. Alan Richardson and Ellen Spolsky. The Work of Fiction: Cognition, Culture, and Complexity. Aldershot: Ashgate: 5184 .

Spurgeon, Caroline F. E. 1935. Shakespeare's Imagery and What It Tells Us. Cambridge: Cambridge University Press.

Stanivukovic, Goran V. 1998. "The city's usuries': Commerce and Cymbeline." Quidditas 19: 229-243.

Sullivan, Ceri 2002. The Rhetoric of Credit: Merchants in Early Modern Writing. London: Associated University Presses.

Swetz, Frank J. 1987. Capitalism and Arithmetic. La Salle, Illinois; Open Court Publishing Co.

Thomas, Keith 1987. "Numeracy in Early Modern England." Transactions of the Royal Historical Society, Fifth Series, 37: 103-132.

Thorne, Alison. "To write and read / Be henceforth treacherous': Cymbeline and the Problem of Interpretation." Eds. Jennifer Richards and James Knolles. Shakespeare's Late Plays: New Readings. Edinburgh: Edinburgh University Press: 176-190.

Turner, Henry S. 2006. The English Renaissance Stage: Geometry, Poetics, and the Practical Spatial Arts. Oxford: Oxford University Press.

Wayne, Valerie 2002. "The woman's parts of Cymbeline." Ed. Jonathan Gil Harris and Natasha Korda. Staged Properties in Early Modern English Drama. Cambridge: Cambridge University Press: 288-315.

- 2008. "Romancing the Wager: Cymbeline's Intertexts." Ed. Mary Ellen Lamb and Valerie Wayne. Staging Early Modern Romance. London: Routledge: $163-87$.

Williams, Gordon 1994. A Dictionary of Sexual Language and Imagery in Shakespearean and Stuart Literature. 3 vols. London: Athlone Press.

Woodbridge, Linda 2003. Ed. Money and the Age of Shakespeare: Essays in New Economic Criticism. New York: Palgrave/St. Martin's.

2010. English Revenge Drama: Money, Resistance, Equality. Cambridge: Cambridge University Press.

How to cite this article:

Parker, Patricia. "Cymbeline: Arithmetic, Double-Entry Bookkeeping, Counts, and Accounts." SEDERI 23 (2013): 95-119.

Submission: 12/07/2013-Acceptance: 5/09/2013 


\title{
The University of Alicante Library copy of Palmerin d'Oliva (London, 1637): A Bibliographical Description
}

\author{
Jordi Sánchez-Martí \\ University of Alicante
}

\begin{abstract}
The purpose of this article is to provide bibliographical information about a copy of the fourth edition of the two parts of Anthony Munday's translation of Palmerin d'Oliva (London, 1637; STC 19160) recently purchased by the University of Alicante Library and not mentioned in the standard bibliographies. The article contains a detailed bibliographical description based on Bowers's principles (1949) and is designed to be useful to scholars by making direct consultation of the copy in most cases unnecessary. The description is preceded by a short introduction to the literary text and its publication in England.

KEYWORDS: Renaissance chivalric literature, Hispanic romances of chivalry, Anthony Munday, Palmerin d'Oliva, Thomas Creed, Bernard Alsop, Thomas Ottley.
\end{abstract}

\section{o. Introduction}

In 1511 Juan de Porras printed the first edition of the anonymous Spanish romance of chivalry Palmerín de Olivia (Salamanca; IB 16737) in the hope of replicating the commercial success achieved by Amadis de Gaula three years earlier (Saragossa, 1508; IB 16414). This publishing decision proved profitable in view of the number of

\footnotetext{
* Research for this article was funded by the Spanish Ministry of Science and Innovation (ref. FFI2011-22811), whose support is herewith gratefully acknowledged. I would also like to thank the staff at the University of Alicante Library, especially Berenice Santonja and María Játiva Victoria, for their diligence and assistance. All images are reproduced by permission of the University of Alicante Library.
} 
editions of Palmerin de Olivia printed throughout the sixteenth century (fifteen in total; IB 16737-16751). Soon the literary fame of Palmerín prompted the composition and publication of new adventures involving the hero and his progeny, including such texts as Primaleón (Saragossa, 1512; not in IB), Platir (Valladolid, 1533; IB 16777), and the Portuguese Palmeirim de Inglaterra by Francisco de Moraes (1543-1544; a Spanish translation appeared in Toledo in 15471548; IB 16732-16733). ${ }^{1}$ This literary phenomenon crossed over the Pyrenees and extended across the Continent. Palmerin de Olivia was first translated into Italian by Michele Tramezino in 1544 and into French by Jean Maugin in 1546 (FB 40395), on whose version the English translation is based. ${ }^{2}$

Anthony Munday (bap. 1560-d. 1633), the English translator, began translating Iberian chivalric romances around 1580 , as can be gathered from the prefatory epistle to his Zelauto (1580), where Munday informs his patron Edward de Vere, 17th Earl of Oxford, that "Not long it will be before [...] the renowned Palmerin of England with all speede shall be sent you" (1963:6). ${ }^{3}$ After translating Palmerin of England, Munday started work on his translation of Palmerin d'Oliva,

\footnotetext{
${ }^{1}$ For a discussion of the Spanish cycle of Palmerín and its authorship, see Marín Pina (1996); for the cycle's English dissemination, see Patchell (1947). For an edition of the Spanish text, see Palmerin de Olivia (2004). Thomas's discussion (1920) of the genre of Iberian chivalric romance is still useful; for a more up-to-date bibliography, however, see Eisenberg and Pina (2000) and the on-line database prepared by Cacho Blecua and Lacarra. For bibliographical descriptions of the Spanish editions of the Palmerín cycle, see García Dini (1966). For Palmeirim de Inglaterra, see Purser (1904).

2 As Galigani (1966:253-254,281-282) has argued, the English translator must have consulted an Italian version of the text. For an analysis of the French translation, see Bettoni (1995:173-201).

${ }^{3}$ For a bibliographical discussion of the chivalric texts translated by Munday, see Hayes (1925, 1926). See also Hamilton (2005:73-112), Phillips (2010:121-151) and Turner (1928:180-183). Since the earliest surviving copy of Palmerin of England is from the 1596 edition, Hamilton contends that this romance might not have been printed until then. This view has not gained scholarly support and more recently Moore has maintained that "Munday probably began his enterprise with the two parts of Palmerin of England" (2010:338). Whether Palmerin of England was printed first in 1581 or 1596, there is no denying that this is the first chivalric romance Munday translated into English. For biographical information on Munday, see also Bergeron (2004) and Hill (2004). On Edward de Vere, see Nelson (2004). Munday's translation of Amadís de Gaula is available in a scholarly edition (Moore:2004). I am currently preparing a critical edition of his Palmerin d'Oliva to appear in the series Medieval and Renaissance Texts and Studies of the Arizona Center for Medieval and Renaissance Studies.
} 
which was published for the first time in 1588 (STC 19157) with a dedication to the same patron as his Zelauto. That translation was reprinted in 1597 (STC 19158) with a change in the dedicatee: instead of the Earl of Oxford, the second edition is dedicated to Francis and Susan Young. ${ }^{4}$ The third edition of Palmerin d'Oliva was published in 1615-1616 (STC 19159, 19159a) by Thomas Creede in collaboration with Bernard Alsop. ${ }^{5}$ The latter was also involved in the fourth edition of 1637 (STC 19160), a copy of which has been newly acquired by the University of Alicante Library. Alsop also worked with an associate, as the title-page indicates: "for B. ALSOP and T. FAWCET, dwelling in Grub-street neere the lower Pumpe."6 When Thomas Creede died in 1616 Alsop inherited his printing equipment (Yamada 1994:11) and later formed a partnership with Thomas Fawcet, who became free of the Company of Stationers on 7 May 1621. ${ }^{7}$ It should therefore come as no surprise that some of Creede's ornaments and ornamental capitals reappear in the 1637 edition of Palmerin d'Oliva, as the bibliographical description below reveals.

As in the case of the third edition, the first part (henceforth Palmerin d'Oliva I) of the 1637 edition is dedicated to the Youngs and the second part (henceforth Palmerin d'Oliva II) to Edward de Vere. Such a correlation suggests that the fourth edition is descended from the third, a logical possibility considering both Alsop's participation in the printing of the latter and the chronological sequence of the editions. In the only article to date discussing the genetic relation of the four editions, Hayes initially states that the 1637 edition was "identical with that of 1616" (1925:70). Confusingly, later in the article Hayes (1925:75-76) seems to suggest that Palmerin d'Oliva I is based not on the third but on the second edition and that the 1637 Palmerin d'Oliva II is a reprint of the first edition. Hayes provides no textual evidence to support either of these claims, which seem to be based on the identity of the dedicatees of both parts of the romance:

\footnotetext{
${ }^{4}$ Wilson (2011:126) states that Young was a merchant.

${ }^{5}$ For biographical information on Creede, see Gants (2004) and Yamada (1994:3-11). For information on Alsop, see Plomer (1907:3-4).

${ }^{6}$ Note that the STC mentions a variant imprint replacing for with by. This variant occurs in the copy at the John Rylands University Library of Manchester. For locating the whereabouts of Alsop's printshop, see STC, 3:251 (I.6).

${ }^{7}$ Cf. Arber 3: 685, 700, 701. For more biographical information on Fawcet, see Plomer (1907:72).
} 
the second edition (like the third and fourth edition of Palmerin $d^{\prime}$ Oliva $I$ ) is dedicated to the Youngs and the first edition (like the third and fourth edition of Palmerin d'Oliva II) to Edward de Vere. An example will suffice to disambiguate Hayes's position. On the final page of chapter 1 of Palmerin d'Oliva I, the 1637 edition, in agreement with the third edition, reads, "but by consent of the Emperour and I" (sig. $7^{\mathrm{v}}$; my italics). By contrast, the first and second editions depart from the other two in reading, "but the Emperour and I." As to Palmerin d'Oliva II, the fourth edition on the last page of chapter 1 reads, "conducted her into a most Princely Chamber" (sig. $\mathrm{A} 6^{\mathrm{v}}$; my italics), again agreeing with the third, whereas the second edition reads "conducted her into a marvailous princely Chamber" (my italics; no copy of the first edition of Palmerin d'Oliva II survives). These two examples show a correspondence between the third and the fourth editions and a departure of these two editions from the second, thus confirming that the 1637 edition is textually derived from the third edition of 1615-1616.

\section{Bibliographical Description}

\section{Volume 1}

Title-page: Palmerin D'Oliva. | THE FIRST PART: | [rule] SHEWING | THE MIRROVR OF NOBI- | litie, the Map of Honour, Anatomie of rare | Fortunes, Heroicall prefidents of Love, won- $\mid$ der of Chivalrie, and the moft accomplifhed | Knight in all perfection. | [rule] Prefenting to Noble minds, their Courtly defire, | to Gentiles their expectations, and to the inferiour | fort, how to imitate their Vertues: Handled with | modeftie to hun offence, yet delightfull | for Recreation. | [rule] Written in Spanilh, Italian, and French: and from | them turned into Englifh, by A. M. one of the | Meflengers of his Majefties | Chamber. | Patere \& A[swash itl.]bstine $>$. | [orn. Yamada 15] | LONDON, | Printed for B. ALSOP and T. FAVVCET, dwelling in | Grub-Jtreet neere the lower Pumpe. | 1637.

Head-title: [double rule] [orn.] THE FIRST PART | OF THE ANCIENT | and honourable Hiftorie of the | valiant Prince Palmerin D'Oliva, | Emperour of Conftantinople ; | Sonne to King FLORENDOS of Macedonia, | and the Faire GRIANA, Daughter to Re- | micius, 
Emperour of Conftantinople : | a Hiftory full of fingular and | Courtly recreation. [rule].

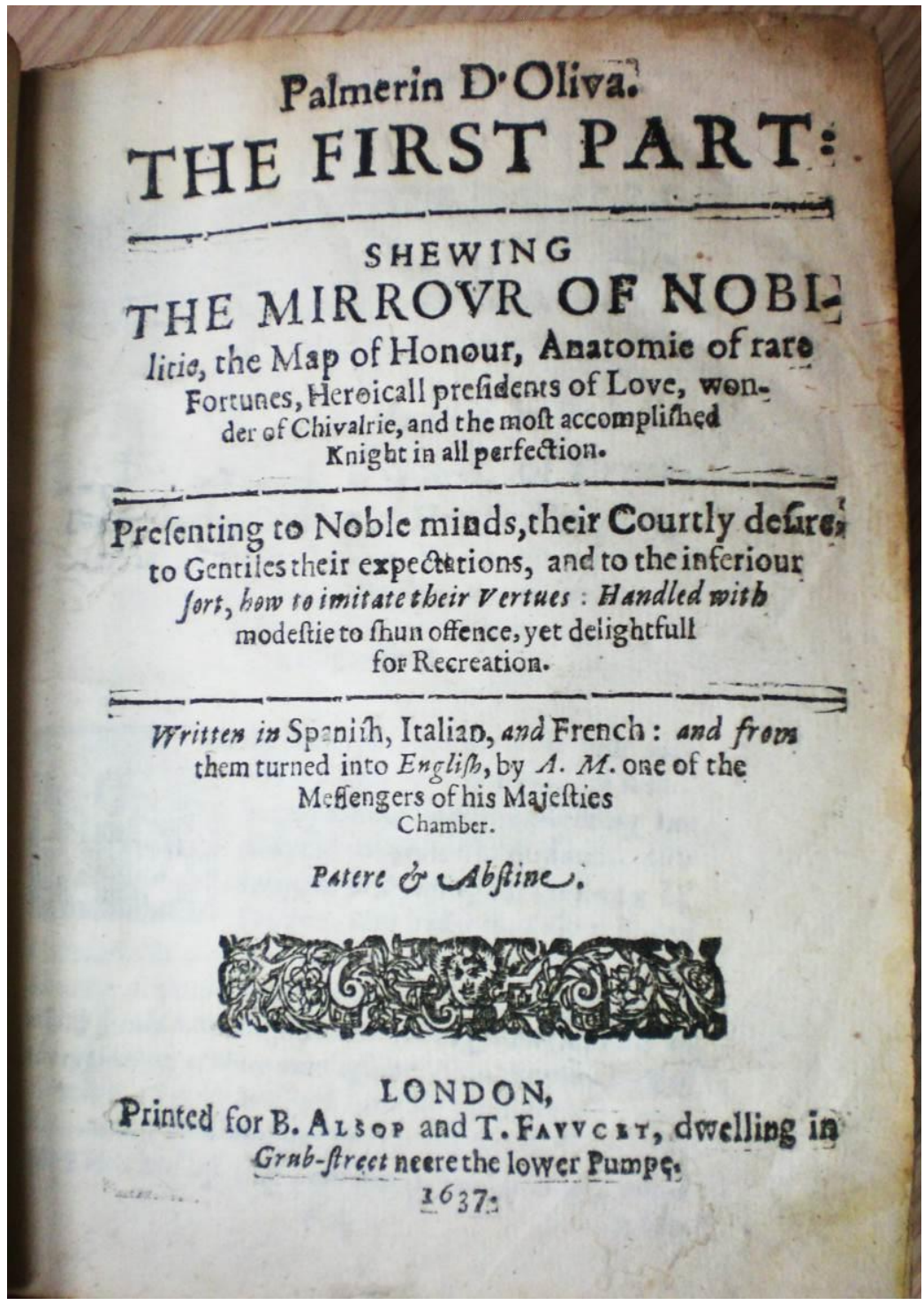

Figure 1. Palmerin d'Oliva, part I (London, 1637), title-page. 
Running-title: [rule] The Hiftorie of Palmerin D'Oliva, | Emperour of Conftantinople. PART. 1. [rule] [Hiftory $\mathrm{A}_{5}-8^{\mathrm{v}}, \mathrm{B}_{1}^{\mathrm{v}}, \mathrm{B}_{3}-4^{\mathrm{v}}, \mathrm{C}_{1}^{\mathrm{v}}, \mathrm{C}_{3}{ }^{\mathrm{v}}$, $\mathrm{D} 2-3^{\mathrm{v}}, \mathrm{E}_{1}{ }^{\mathrm{v}}, \mathrm{E} 3^{\mathrm{v}}, \mathrm{F} 2-3^{\mathrm{v}}, \mathrm{G} 2-3^{\mathrm{v}}, \mathrm{H}_{3} \mathrm{v}, \mathrm{H}_{7}-8^{\mathrm{v}}, \mathrm{I} 6-7^{\mathrm{v}}, \mathrm{K} 6-7^{\mathrm{v}}, \mathrm{L}_{5}{ }^{\mathrm{v}}, \mathrm{L}^{\mathrm{v}}, \mathrm{M}_{5}^{\mathrm{v}}$, $\mathrm{M}_{7}^{\mathrm{v}}, \mathrm{N}_{7}-8^{\mathrm{v}}, \mathrm{O} 6-7^{\mathrm{v}}, \mathrm{P}_{5}-6^{\mathrm{v}}, \mathrm{Q}_{7}-8^{\mathrm{v}}, \mathrm{S}_{5}^{\mathrm{v}}, \mathrm{S}^{\mathrm{v}}, \mathrm{T} 6^{\mathrm{v}}, \mathrm{T} 8^{\mathrm{v}}, \mathrm{V} 6-7^{\mathrm{v}}, \mathrm{X} 6^{\mathrm{v}}, \mathrm{X}^{\mathrm{v}}$, $\mathrm{Y} 7^{\mathrm{v}} ; \mathrm{Y}^{\mathrm{v}}-7^{\mathrm{r}}$ invert the two parts of the RT; $\mathrm{Y}^{\mathrm{v}}-\mathrm{Z}^{\mathrm{r}}{ }^{\mathrm{r}}$ print ${ }^{\mathrm{N}}$ Emperour of Conftantinople. PART. 1.' in both parts of RT].

Collation: $4^{\circ}: \mathrm{A}-\mathrm{Y}^{8}, \mathrm{Z}^{4}\left[\$_{4}\left(-\mathrm{A}_{2}, \mathrm{Z}_{4}\right)\right.$ signed; missigning $\mathrm{O}_{3}$ as $\mathrm{O}_{4}$, $\mathrm{S}_{2}$ as $\left.\mathrm{S}_{4}\right], 180$ leaves unnumbered.

Contents: $\mathrm{A} 1$ (blank apart from signature). $\mathrm{A} 2^{\mathrm{r}}$ : title-page (verso blank). $\mathrm{A}^{\mathrm{r}}$ : [double rule] [orn.] | TO | THE WORSHIPFVLL, $\mid \mathrm{M}^{\mathrm{r}}$. FRANCIS YONG, of B[swash ital.]rent- | Pellam [stet], in the County of Hertford Efquire, $\mid$ and to Miftrefle SVSAN YONG his wife, $\mid$ and my moft kind Miftreffe $>$, health, and | their hearts contentment, con- | nually [stet] wilhed.' ital. with 6-line init. $\left(26 \times 26 \mathrm{~mm}\right.$.). A3 ${ }^{\mathrm{v}}$ : dedication ending 'Your poore well-willer | till death, |A. M.' [rule] [orn. Yamada 14] A4: [double rule] [type orn.] 'To the Reader.' rom. with 10line init. $(38 \times 40 \mathrm{~mm}) . \mathrm{A}_{5}^{\mathrm{r}}-\mathrm{Z}_{4}$ : HT and text [b.l.], chap. $1-65$, chap. hd. in rom. except for proper names. $\mathrm{Z}_{4}{ }^{\mathrm{r}}$ : 'FINIS' followed by recapitulation and announcement by the translator, 'A. Mundy. Honos alit Artes.' (verso blank).

Catchwords: $\mathrm{B}_{2}{ }^{\mathrm{v}}$ day [day,] $\mathrm{B}_{4}^{\mathrm{v}}$ here, [heere,] $\mathrm{C}_{2}{ }^{\mathrm{r}}$ (se-)cretly [cretly,] C $8^{\mathrm{v}}$ she [shee] $\mathrm{Di}^{\mathrm{r}}$ yongest [youngest] $\mathrm{E}^{\mathrm{r}}$ faid [fayd] $\mathrm{F}^{\mathrm{v}}$ lone [love] $\mathrm{H}_{5} \mathrm{v}$ folemnized [folemnized,] $\mathrm{H}^{\mathrm{v}}$ (Ptolo-)mes [mies] $\mathrm{I}^{\mathrm{r}}$ (dif-)courle, [difcourfe,] (him-)felfe [felfe,] $\mathrm{M}_{5}^{\mathrm{r}}$ death [death,] $\mathrm{M}^{\mathrm{v}}$ Staves [Staues] $\mathrm{M} 8^{\mathrm{r}}$ accom- [acoompany] $\mathrm{M} 8^{\mathrm{v}}$ having [hauing] $\mathrm{Ni}^{\mathrm{r}}$ (of-)teu [ten] $\mathrm{O}_{3}{ }^{\mathrm{r}}$ world. [world,] $\mathrm{O}_{4}{ }^{\mathrm{v}}$ Country [Countrey] $\mathrm{O}_{5}{ }^{\mathrm{r}}$ (pro-)céeding [céeding,] O8 ${ }^{\mathrm{v}}$ CHAP. XLII. [CHAP. XLIII.] $\mathrm{P}_{1}{ }^{\mathrm{r}}$ happe [hap] $\mathrm{P}^{\mathrm{r}}$ Citty [City,] $\mathrm{P}_{7}^{\mathrm{r}}$ con- [Conquer] $\mathrm{Q}^{\mathrm{v}}$ (beau-)ty [tie] $\mathrm{Q}^{\mathrm{r}}{ }^{\mathrm{r}}$ loofe [lofe] Q8 ${ }^{\mathrm{v}}$ CHAP. XLVIII. [CHAP. L.] $\mathrm{R}_{3}{ }^{\mathrm{r}}$ refpect [refpect,] $\mathrm{R}_{5}{ }^{\mathrm{r}}$ (vnhappi-)ly [lie] $\mathrm{R}_{5}{ }^{\mathrm{v}}$ fighes [fighes,] $\mathrm{V}_{2}^{\mathrm{v}}$ Befides, [Befides] $\mathrm{V}^{\mathrm{r}}$ (afflicti-)ons [ons,] $\mathrm{X}_{1}{ }^{\mathrm{r}}$ neuer [never] $\mathrm{X}_{4}{ }^{\mathrm{v}}$ (Pal-)merin [merin,] $\mathrm{Y}_{5}{ }^{\mathrm{v}}$ finger [finger,] $\mathrm{Y}^{\mathrm{r}}$ Believe [Beléeue] $\mathrm{Z}_{1}{ }^{\mathrm{r}}$ (deter-)mined [determined] $\mathrm{Z}_{2}{ }^{\mathrm{v}}$ (afflicti-)ons? [afflictions?]; no $\mathrm{cw}$ on $\mathrm{Mr}^{\mathrm{r}}, \mathrm{M}_{4}{ }^{\mathrm{v}}$ [probably damaged].

Typography: 35 ll., 144 ( 160 to top rule of headline) x $90 \mathrm{~mm}$. $\left(\mathrm{H}_{1} \mathrm{v}\right)$; text, black letter (and some roman and italic) $82 \mathrm{~mm}$. for $20 \mathrm{ll}$;; dedication: italic $94 \mathrm{~mm}$. $\left(\mathrm{A}_{3}{ }^{\mathrm{r}}\right)$; 'To the Reader.': roman $82 \mathrm{~mm}$. $\left(\mathrm{A}_{4}{ }^{\mathrm{v}}\right)$; headline roman and italic. Capitals used from Thomas Creede's 
stock (following Yamada 1994: 84-86): B1 (ch. 21, 57), E1 (ch. 13, 28, 61), $F_{1}$ (ch. 7), Gi (ch. 26, 35), L1 (ch. 32), Mi (ch. 24), N1 (ch. 50), an altered form of Q1 used for ' $\mathrm{O}^{\prime}$ ( (ch. 22, 36, 44, 63), P1 (ch. 30, 38, 55), $\mathrm{S}_{1}(34,39,42,56), \mathrm{T}_{1}$ (ch. 27, 64), T2 (ch. 59; see fig. 2), ${ }^{8} \mathrm{~T}_{3}$ (ch. 15, 23, 40, 46, 51, 62), V1 (ch. 20, 43), W1 (ch. 9, 16, 17, 47, 49, 58), Y1 $(12,18)$.

Chapter 18 misp. 17, chap. 24 misp. 22, chap. 32 misp. 22, chap. 33 misp. 34, chap. 49 misp. 43, chap. 54 misp. 52, chap. 55 misp. 53, chap. 59 misp. 61, chap. 65 misp. 63.


Figure 2. Initials $\mathrm{T}_{2}\left(\right.$ sig. $\mathrm{X}_{3}^{\mathrm{v}}$ ), $\mathrm{T}_{4}\left(\right.$ sig. $\mathrm{L}_{4}^{\mathrm{r}}$ )

Notes: In this copy gathering $\mathrm{V}$ presents an anomaly, since the order of the leaves breaks the textual continuity of the romance. The leaves are bound in the following order: $\left.V_{1}, V_{2}, V_{5}\right], V[6], V_{3}, V_{4}$, $\mathrm{V}[7], \mathrm{V}[8]$. In a quarto in eights a gathering is comprised of "two twice-folded sheets, one quired within the other" (Bowers 1949:201). The error in this copy is caused when the second fold of the sheet nested in is made in the wrong direction, thus altering the textual order. This mistake is attributable to the binder (cf. Gaskell 1972:147). I have consulted the two copies of the fourth edition in the Folger Shakespeare Library, neither of which presents the same anomaly.

\footnotetext{
${ }^{8}$ The fourth edition uses a different ornamental $\mathrm{T}$ featuring a boar, instead of a fox as in Creede's T2. I will designate it as $\mathrm{T}_{4}$ (see fig. 2). This initial heads chapters 10, 33, and 65 .
} 


\section{Volume 2}

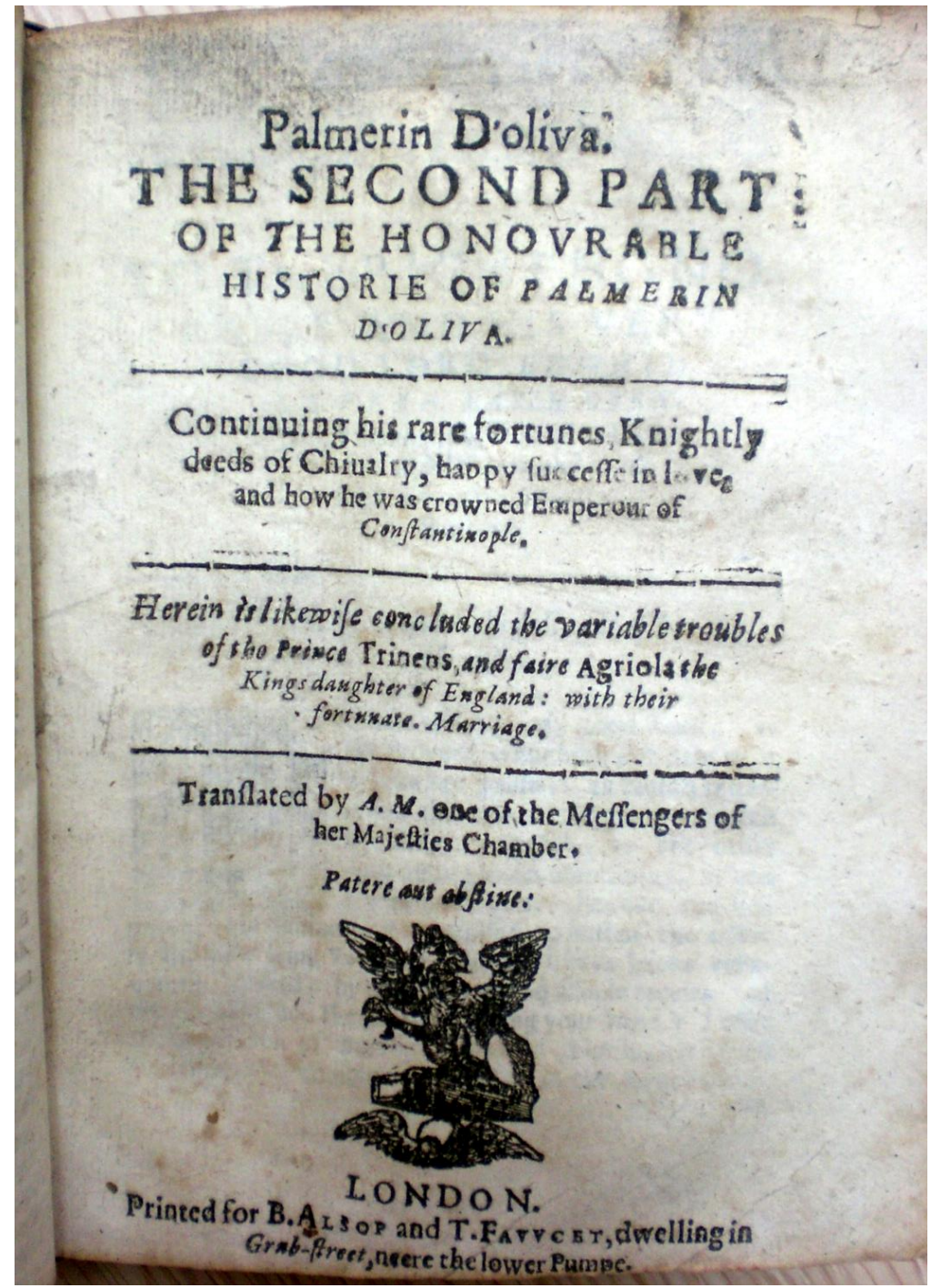

Figure 3. Palmerin d'Oliva, part II (London, 1637), title-page. 
Title-page: Palmerin D'oliva. | THE SECOND PART: | OF THE HONOVRABLE | HISTORIE OF PALMERIN | D'OLIVA. | [rule] Continuing his rare fortunes, Knightly | deeds of Chiualry, happy fuccelfe in love, | and how he was crowned Emperour of | Conftantinople. | [rule] Herein is likewife concluded the variable troubles | of the Prince Trineus, and faire Agriola the | Kings daughter of England: with their | fortunate. Marriage. | [rule] Tranllated by A. M. one of the Meffengers of | her Majelties Chamber. | Patere aut abftine: | [orn. McKerrow 339; Yamada 3] | LONDON. | Printed for B. ALSOP and T. FAVVCET, dwelling in | Grub-street, neere the lower Pumpe.

HT] [orn. Yamada 12] THE SECOND | PART OF THE ANTIENT AND HONORA- | ble Hiftory of Palmerin D'Oliva. Continuing his rare Fortunes, Knightly deedes of | Chiualry, happy fuccefse in Love, and how he was crow | ned Emperour of Conftantinople. Herein | is likewife concluded the variable trou- | bles of Tryneus, and faire Agriola | of England, with their for- $\mid$ tunate Marriage. Ec. [rule].

RT] [rule] The Hiftory of [Of NOSTYZAa1 ${ }^{\mathrm{v}}, \mathrm{LMRX}_{2}{ }^{\mathrm{v}}, \mathrm{MPQTV}_{3}{ }^{\mathrm{v}}$, ANOPQRSVXYZAaBb4 ${ }^{\mathrm{v}}$ ] Palmerin D'Oliva. [D'Oliva^STYZAa1 ${ }^{\mathrm{v}}$, $\mathrm{ORX}_{2}{ }^{\mathrm{v}}, \mathrm{TV}_{3}{ }^{\mathrm{v}}, \mathrm{ORSVXYZAa}_{4}^{\mathrm{v}}$; DOliva. $\left.\mathrm{K}_{4}^{\mathrm{v}}, \mathrm{L}^{\mathrm{v}}\right]$ Emperour of Conftantinople. PART. 2. [Conantnople $\mathrm{L}_{3}^{\mathrm{r}} ; 2$ turned T6,8 $; 2 \wedge \mathrm{A} 5,7^{\mathrm{r}}$, I1$2^{\mathrm{r}}, \mathrm{K} 5-6,8^{\mathrm{r}}, \mathrm{L} 2-4^{\mathrm{r}}, \mathrm{O} 2-3^{\mathrm{r}}, \mathrm{S} 5-6^{\mathrm{r}}, \mathrm{TVXYZAa} 5-8^{\mathrm{r}}, \mathrm{Aa}_{2}{ }^{\mathrm{r}}, \mathrm{Bb}_{5}{ }^{\mathrm{r}}$ ] [rule] [Oliva with turned $a \mathrm{~A}_{5}^{\mathrm{v}} ; \mathrm{F}_{7}{ }^{\mathrm{v}}-\mathrm{F}^{\mathrm{r}}$ invert the two parts of the RT; $\mathrm{G}^{\mathrm{v}}-\mathrm{G}_{7}^{\mathrm{r}}$ print 'The Hiftory of Palmerin D'Oliva.' in both parts of RT; G8 ${ }^{\mathrm{v}}-\mathrm{Hi}^{\mathrm{r}}$ print 'Emperour of Conftantinople. PART. 2.' in both parts of RT].

Collation: $4^{\circ}: \mathrm{A}^{-2} \mathrm{~B}^{8}(-2 \mathrm{~B} 7-8)$ [\$4 signed; misprinting $\mathrm{G}_{4}$ as $\mathrm{G}_{2}$, $\mathrm{J}[1]$ a $\mathrm{F}[1], \mathrm{H}_{4}$ as $\mathrm{H}_{2}, \mathrm{~N}[1]$ as $\mathrm{M}[1], \mathrm{O}_{3}$ as $\left.\mathrm{M}_{3}\right]$, 196 leaves unnumbered.

Contents: Ar ${ }^{\mathrm{r}}$ : title-page (verso blank). A2: [orn. Yamada 12] | 'TO THE RIGHT HONO- | RABLE AND HIS VERY | GOOD LORD EDWARD | DE VERE, EARLE OXEN- | ford, Vifcount, Bulbecke, Lord San- | ford of Badelefmere, and Lord | high Chamberlaine of | England. [rule] A. M. Wifheth full iffue of his $\mid$ noble defires.' rom. with 7-line initial [Yamada P1] (27 x 27 mm.). A3: [type orn.] 'TO THE FRIENDLY | READERS', ital. with 6-line initial [Yamada Y1] $(28 \times 27$ mm.). A4 $4^{\mathrm{r}}-\mathrm{Bb} 6^{\mathrm{v}}$ : HT and text [b.l.], chap. 1-67, chap. hd. in rom. except for proper names. Bb6 ${ }^{\mathrm{v}}$ : 'FINIS.' 
Catchwords: $\mathrm{A} 3^{\mathrm{r}}$ Sonne [Jon] $\mathrm{A}_{5}^{\mathrm{r}}$ (Fa-)vour [vour,] $\mathrm{A} 5^{\mathrm{v}}$ honor [honor,] A8 ${ }^{\mathrm{v}}$ Aneas [ÆEneas] B2 ${ }^{\mathrm{v}}$ CHAP. IV. [CHAP. III.] B6 ${ }^{\mathrm{v}}$ God [The] $\mathrm{B}^{\mathrm{v}}$ CHAP. VII. [CHAP. VI.] $\mathrm{D}^{\mathrm{v}}{ }^{\mathrm{v}}$ lignes, [fignes.] ${ }_{5}{ }^{\mathrm{r}}$ CHAP. XIII. [CHAP. XIIII.] $\mathrm{F}_{2}{ }^{\mathrm{r}}$ thinke [hinke] $\mathrm{F}_{2}{ }^{\mathrm{v}}$ colours [colours,] $\mathrm{F}_{3}{ }^{\mathrm{r}}$ Madam [Madam,] $\mathrm{G}_{1}{ }^{\mathrm{v}}$ any [further] $\mathrm{H}_{4} \mathrm{v}$ hereof [hereof,] $\mathrm{H}_{6}{ }^{\mathrm{r}}$ me, [me.] $\mathrm{K}_{5}^{\mathrm{v}}$ ber' [her,] $\mathrm{L}^{\mathrm{r}}$ ekéef [féeke] $\mathrm{L}^{\mathrm{v}}$ (apper-)tained, [taine,] $\mathrm{L}^{\mathrm{v}}$ (perfor-)mance [manen] $\mathrm{M}^{\mathrm{v}}$ thanks [thanks,] $\mathrm{M}_{4}^{\mathrm{v}}$ Madame, [Madam,] M8 $8^{\mathrm{r}}$ CHAP. XXXIII. [CHAP. XXXII.] $\mathrm{P}_{2}{ }^{\mathrm{r}}$ (boun-)den [den.] $\mathrm{P}_{4}{ }^{\mathrm{v}}$ (en-)tered [tred] $\mathrm{Q}_{2}{ }^{\mathrm{r}}$ Befide [Befide,] $\mathrm{Q}^{\mathrm{r}}$ Citie [Citty] $\mathrm{Q}^{\mathrm{v}}$ Hyppolita [Hypolita,] Q8 ${ }^{\mathrm{v}}$ CHAP. XLIV. [CHAP. XLIIII.] R4 ${ }_{4}^{\mathrm{r}}$ Ifle [IIle,] $\mathrm{S}_{4}^{\mathrm{r}}$ an [and] $\mathrm{T}_{1}{ }^{\mathrm{r}}$ Palmeri [Palmerin] $\mathrm{T}_{2} \mathrm{v}$ (be-)fore [fore:] $\mathrm{T}_{3}^{\mathrm{v}}$ honours [honors] $\mathrm{T}_{5} \mathrm{v}$ highnes [Highneffe] T $6^{\mathrm{v}}$ CHAP. LI. [CHAP. LIII.] V4 ${ }^{\mathrm{r}}$ (grea-)ter [ter,] V6 ${ }^{\mathrm{r}}$ Need[Néedleffe] $\mathrm{X}_{1}{ }^{\mathrm{r}}$ (La-)dy, [die,] $\mathrm{Y}_{2}{ }^{\mathrm{v}}$ Trineus [Tryneus] $\mathrm{Z}_{1}{ }^{\mathrm{v}}$ delight [delight,] $\mathrm{Z}_{3}^{\mathrm{r}}$ doth [do h] $\mathrm{Z}_{4}^{\mathrm{r}}$ faid [faid:] $\mathrm{Z}_{5}^{\mathrm{r}}$ meane [mean] Aa1 ${ }^{\mathrm{v}}$ defence [defence,] $\mathrm{Aa}_{2}{ }^{\mathrm{v}}$ (pa-)tience [tience,], $\mathrm{Aa}^{\mathrm{r}}{ }^{\mathrm{r}}$ (Em-)perour [perour,] Aa6 ${ }^{\mathrm{r}}$ highly [hlghly], Aa8 ${ }^{\mathrm{v}}$ nor [not].

Typography: 35 ll. 143 (157 to top rule of headline) x $89 \mathrm{~mm}$. $\left(\mathrm{A}_{5}^{\mathrm{v}}\right.$ ); text, black letter (and some roman and italic) $82 \mathrm{~mm}$. for 2011 ;; dedication: roman $82 \mathrm{~mm}$. $\left(\mathrm{A}_{2}{ }^{\mathrm{r}}\right)$; 'TO THE FRIENDLY | READERS': italic $94 \mathrm{~mm}$. $\left(\mathrm{A}_{3}{ }^{\mathrm{r}}\right)$. Chapter 4 misp. 3, chap. 19 misp. 18, chap. 23 misp. 24, chap. 33 misp. 32, chap. 59 misp. 57. Capitals used from Thomas Creede's stock (following Yamada 1994:84-86): B1 (ch. 21, 57), E1 (ch. 3, 14, 15, 18, 57, 63), C1 (ch. 34, 61), E1 (ch. 8), F1 (ch. 59), G1 (ch. 29), H1 (ch. 2, 20), Li (ch. 25, 44), M1 (ch. 7, 52, 66), N1 (ch. 4, 19, 21, 24, 36, 40, 41, 53), P1 (sig. A2 ${ }^{\mathrm{r}}$, ch. 5, 22, 28, 31, 43, 50, 55), S1 (ch. 9, 16, 23, 65), T2 (ch. 27, 32, 37, 46, 49, 56, 58, 67), V1 (ch. 26, 64), $\mathrm{Y}_{1}\left(\right.$ sig. $\left.\mathrm{A} 3^{\mathrm{r}}\right){ }^{9}$

Notes: This copy lacks $\mathrm{Bb}_{7}{ }^{\mathrm{r}}$, which contains the translator's address to readers, an announcement and 'FINIS.' (verso blank); a facsimile reproduction has been added. On the title-page the year was cropped when the edges of the book were cut before binding (cf. Gaskell 1972:148), although it is visible on the other copies consulted. There is a textual lacuna at the beginning of $\mathrm{B}^{\mathrm{r}}$ (cf. catchword discrepancy); the 1616 edition used as copy-text reads as follows: 'God difpofed of him: made faft the doore after him, and with his fword drawne, and his Mantle wraped about his arme, went to fée how the Beastes would deale with him' (sig. $\mathrm{B}^{\mathrm{r}}$ ).

\footnotetext{
${ }^{9} \mathrm{~T}_{4}$ is used as the initial capital in chapters 12 and 17 ; see fig. 2 above.
} 
Other copies examined: Folger Shakespeare Library (STC 19160) copies 1 and 2.

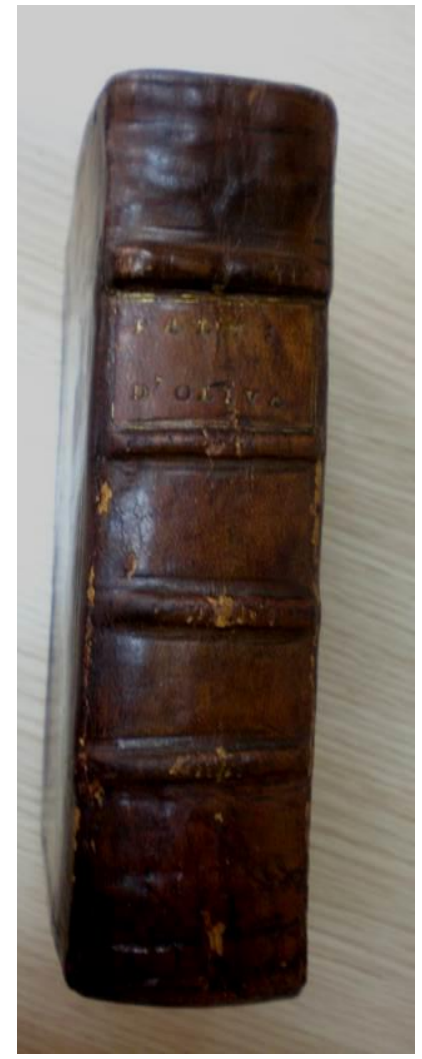

Figure 4. Binding and spine.

Binding: Brown leather in pasteboard with double-fillet borders blind-tooled on front and back cover; four raised bands across the spine of the book with title gold-lettered with decorative bands: 'PALM: | D'OLIVA' (see fig. 4). Front flyleaf with contemporary ownership inscriptions (see fig. 5).

Provenance: On the front flyleaf we can read the ownership inscriptions of Thomas Ottley, Richard Ottley and Marg[ar]et Wolryche (see fig. 5). We can infer that the book was bought by and bound for the Ottleys of Pitchford. ${ }^{10}$ It seems likely that the names

\footnotetext{
${ }^{10}$ For more information about this family, see Hawkesbury (1895).
} 
refer to Sir Richard Ottley (bap. 15 Sept. 1626), Gentleman of H. M. Privy Chamber, and his son Thomas Ottley (b. 30 Jan. 1650- $d$. 11 May, 1695). The connection between the Ottleys and the Wolryches began in 1625 with the marriage of Ursula Ottley (b. 9 Aug. 1607) to Sir Thomas Wolryche, Bt. (Hawkesbury 1895:365). ${ }^{11}$ The couple had twelve children, one being Francis (ca. 1627-1688). The Deeds and Papers Relating to the Dudmaston Estate of the Wolryche Family contain a "Declaration of release of obligation" (ref. 2922/3/48), dated 27 August 1675, relating to a Margaret Wolryche (b. 1653), daughter of Sir Francis Wolryche, who most probably is the woman who inscribed her name on the flyleaf of the Alicante copy. ${ }^{12}$

The University of Alicante Library acquired the book from $\mathrm{H}$. M. Fletcher (Wynches Barn, Much Hadham, Herts.) in 2012 for $£ 2,350.00$.

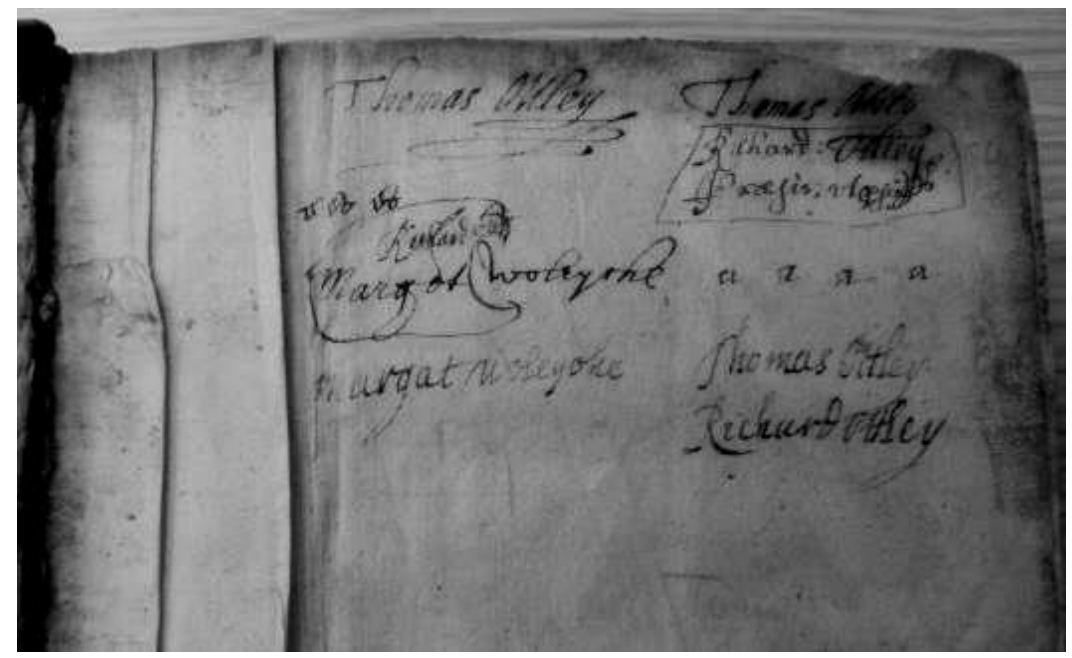

Figure 5. Front flyleaf.

\footnotetext{
${ }^{11}$ See Hopper (2004), but cf. the licence of alienation dated 1 Sept. 1626 in the Deeds and Papers Relating to the Dudmaston Estate of the Wolryche Family, ref. 2922/3/32.

${ }^{12}$ For the taste of women for Iberian romances of chivalry in seventeenth-century England, see Hackett (2000:66-68).
} 


\section{References}

Arber, Edward 1875-1894. A Transcript of the Registers of the Company of Stationers of London, 1554-77. 5 vols. London and Birmingham: Privately printed.

Bergeron, David M. 2004. "Munday, Anthony (bap. 1560, d. 1633)." ODNB 39: 739-746.

Bettoni, Anna 1995. "Il Palmerín de Olivia tradotto da Maugin: editori, storie e mode letterarie nella Francia del Cinquecento." "Il n'est nul si beau passe temps Que se jouer à sa Pensee": Studi di filologia e letteratura francese in onore di Anna Maria Finoli. Pisa: ETS: 173-201.

Bowers, Fredson 1949. Principles of Bibliographical Description. Princeton: Princeton University Press.

Cacho Blecua, Juan Manuel and María Jesús Lacarra. "Amadís: Base de datos de literatura caballeresca." Clarisel. Universidad de Zaragoza. <url: http://clarisel.unizar.es.>. Last accessed 17/07/2013.

Deeds and Papers Relating to the Dudmaston Estate of the Wolryche Family. Shropshire Archives, Shrewsbury.

Eisenberg, Daniel and $\mathrm{M}^{\mathrm{a}}$ Carmen Marín Pina 2000. Bibliografía de los libros de caballerías castellanos. Zaragoza: Prensas Universitarias de Zaragoza.

FB > see Pettegree (2007).

Galigani, Giuseppe 1966. "La versione inglese del Palmerín de Olivia." Eds. G. G. Mancini and G. di Stefano. Studi sul "Palmerín de Olivia." Istituto di Letteratura Spagnola e Ispano-Americana 13. Pisa: Università di Pisa, vol. 3: 239-288.

Gants, David L. 2004. "Creede, Thomas (b. in or before 1554, d. 1616)." ODNB 14: 128-129.

García Dini, Encarnación 1966. "Per una bibliografia dei romanzi di cavalleria: Edizioni del ciclo dei 'Palmerines.'” Eds. G. G. Mancini and G. di Stefano. Studi sul "Palmerín de Olivia." Istituto di Letteratura Spagnola e Ispano-Americana 13. Pisa: Università di Pisa, vol. 3: 5-43.

Gaskell, Philip 1972. A New Introduction to Bibliography. Oxford: Clarendon Press.

Hackett, Helen 2000. Women and Romance Fiction in the English Renaissance. Cambridge: Cambridge University Press.

Hamilton, Donna B. 2005. Anthony Munday and the Catholics, 1560-1603. Burlington, Vt.: Ashgate. 
Hawkesbury, Lord 1895. "The Family of Ottley of Pitchford." Transactions of the Shropshire Archaeological and Natural History Society, 2nd. ser. 7: 36138 o.

Hayes, Gerald R. 1925. "Anthony Munday's Romances of Chivalry." The Library, 4th ser. 6: 57-81.

— 1926. "Anthony Munday's Romances: A Postcript." The Library, 4th ser. 7: $31-38$.

Hill, Tracey 2004. Anthony Munday and Civic Culture: Theatre, History and Power in Early Modern London 1580-1633. Manchester: Manchester University Press.

IB > see Wilkinson (2010).

Hopper, Andrew J. 2004. "Wolryche, Sir Thomas, first baronet (1598-1668)." ODNB 60: 2-3.

Mancini, Giancarlo Guido and Giuseppe di Stefano eds. 1996. Studi sul "Palmerín de Olivia." 3 vols. Istituto di Letteratura Spagnola e IspanoAmericana 13. Pisa: Università di Pisa.

Marín Pina, María Carmen 1996. "El ciclo español de los Palmerines." Voz y Letra 7/2: 3-27.

Matthew, H. C. G. and Brian Harrison eds. 2004. Oxford Dictionary of National Biography. 61 vols. Oxford: Oxford University Press. [ODNB]

McKerrow, Ronald B. 1913. Printers' $\mathcal{E}$ Publishers' Devices in England $\mathcal{E}$ Scotland, 1485-1640. London: The Bibliographical Society.

Moore, Helen ed. 2004. Amadis de Gaule, Translated by Anthony Munday. NonCanonical Early Modern Popular Texts. Burlington, Vt.: Ashgate.

2010. "Ancient and Modern Romance." Eds. Gordon Braden et al. The Oxford History of Literary Translation in English, vol. 2: 1550-1660. Oxford: Oxford University Press: 333-346.

Munday, Anthony 1963 (1580). Zelauto: The Fountaine of Fame. Ed. Jack Stillinger. Carbondale, Ill.: Southern Illinois University Press.

Nelson, Alan H. 2004. "Vere, Edward de, seventeenth earl of Oxford (15501604)." ODNB 56: 286-289.

ODNB > see Matthew and Harrison (2004).

Patchell, Mary 1947. The "Palmerin" Romances in Elizabethan Prose Fiction. Columbia University Studies in English and Comparative Literature 166. New York, N.Y.: Columbia University Press.

Pettegree, Andrew et al. eds. 2007. French Vernacular Books: Books Published in the French Language before 1601. 2 vols. Leiden: Brill. [FB]

Phillips, Joshua 2010. English Fictions of Communal Identity, 1485-1603. Burlington, Vt.: Ashgate. 
Plomer, H. R. 1907. A Dictionary of the Booksellers and Printers who were at work in England, Scotland and Ireland from 1641 to 1667. London: Bibliographical Society.

Pollard, A.W. et al. eds. 1976-91. A Short-Title Catalogue of Books Printed in England, Scotland and Ireland 1475-1640. 3 vols. 2nd ed. London: Bibliographical Society. [STC]

Purser, William Edward 1904. Palmerin of England: Some Remarks on this Romance and on the Controversy concerning its Authorship. Dublin: Browne and Nolan.

STC > see Pollard (1976-1991).

Stefano, Giuseppe di ed. 2004 (1511). Palmerin de Olivia. In collaboration with Daniela Pierucci and with an introduction by $\mathrm{M}^{\mathrm{a}}$ Carmen Marín Pina. Los Libros de Rocinante 18. Alcalá de Henares: Centro de Estudios Cervantinos.

Thomas, Henry 1920. Spanish and Portuguese Romances of Chivalry: The Revival of the Romance of Chivalry in the Spanish Peninsula, and Its Extension and Influence Abroad. Cambridge: Cambridge University Press.

Turner, Celeste 1928. Anthony Mundy: An Elizabethan Man of Letters. University of California Publications in English 2/1. Berkeley, Calif.: University of California Press.

Wilkinson, Alexander S. ed. 2010. Iberian Books: Books Published in Spanish or Portuguese or in the Iberian Peninsula before 1601. Leiden: Brill. [IB]

Wilson, Louise 2011. "Playful Paratexts: The Front Matter of Anthony Munday's Iberian Romance Translations." Eds. Helen Smith and Louise Wilson. Renaissance Paratexts. Cambridge: Cambridge University Press.

Yamada, Akihiro 1994. Thomas Creede: Printer to Shakespeare and His Contemporaries. Tokyo: Meisei University Press.

How to cite this note:

Sánchez-Martí, Jordi. "The University of Alicante Library copy of Palmerin d'Oliva (London, 1637): A Bibliographical Description." SEDERI 23 (2013): 123-137.

Author's contact: jordi.sanchez@ua.es

Submission: 28/02/2013 - Acceptance: 24/04/2013 


\title{
Sixteenth-Century Italian, French, Spanish and English Language Learning Material. A Bibliographical Study
}

\author{
Rocío G. Sumillera \\ Universidad de València
}

\begin{abstract}
This bibliographical study offers a list of the first printed language manuals in Western Europe expressly designed to teach a particular foreign language to speakers of a particular tongue. Hence, the study lists references to sixteenth-century grammars, dictionaries and language handbooks with the possible linguistic combinations of Italian, French, Spanish and English, the first three being the most popular modern languages in sixteenthcentury Western Europe and hence the most representative ones offering an insight into the foreign language learning map of the time. The bibliographical study is preceded by an introduction to the manner in which foreign tongues were taught and learned in the early modern period, and is completed by a selection of references to secondary sources that have been researched on each linguistic combination.
\end{abstract}

KEYWORDS: early modern language manuals, sixteenth-century grammars, sixteenth-century dictionaries

In the Middle Ages in Europe, Latin occupied a position of supremacy over vernaculars as the language of the Church and diplomacy, and the main vehicle for the transmission of culture and knowledge. However, as early as the ninth century dialogue manuals and phrasebooks started to appear in response to the demands of traders and travelers. This was the case of two books for instruction in German to upper-class adult speakers of Romance dialects: the Kasseler Gespräche (ninth century), which taught the Bavarian dialect of Old High German, and the Altdeutsche Gespräche or Pariser Gespräche (eleventh century), which provided instruction in 
the colloquial Northwest Franconian (Herbert Penzl 1984). Other short dialogues and glossaries were produced in Greek, Hebrew, Arabic and even Basque to help pilgrims and other Western European travelers and merchants communicate more easily (Brefeld 1994; Kibbee 2000). In addition to commercial transactions, business and trade, knowledge of vernacular tongues also proved of great importance in Christian missions, for even if Latin was the language of the Church, the missionaries would try to learn the vernacular to communicate with the locals, preach, and translate parts of the Bible without the mediation of interpreters (Bischoff 1961:223). From the twelfth, and particularly from the thirteenth century onwards, the supremacy of Latin began to crumble as the vernaculars initiated a process of vindication of their worth to become vehicles of knowledge and culture too.

During the Renaissance, the importance of studying languages multiplied. Even if the stress continued to fall on Latin in the context of classroom language teaching, vernacular languages, particularly French and Italian, got the attention of a wider public interested in learning them. This was partly due to, among other factors, the increase of international travel and cultural and commercial exchanges, as well as an undermining of the dominance of Latin and the rise of the vernacular languages and their literatures. The combination of the invention of the printing press with a growing interest in languages fostered the multiplication of didactic material for instruction in vernacular foreign tongues. Indeed, the appearance of printed handbooks revolutionized the way in which vernacular tongues were taught and learnt, for travelling to foreign countries and private tuition ceased being the only two ways of learning a language. Furthermore, both these methods were "available exclusively to members of the aristocracy or gentry, at least until the latter part of the [sixteenth] century, and, in the case of foreign travel, available only to men" (Lawrence 2005:6). Printed language instruction material thus inaugurates an era of great numbers of autodidacts. At the roots of the study of foreign tongues, there lay a combination of the humanist agenda with a clear utilitarian purpose of a commercial, business-related, educational, or merely leisurederived nature. As a result, fifteenth and particularly sixteenthcentury Europe was flooded with the publication of a wide and varied range of printed materials for the learning of foreign modern tongues: grammars, conversation manuals, books of dialogues, 
compendia of proverbs and letters, dictionaries and glossaries, and volumes that combine in different degrees elements of all the former. Western European students of vernacular languages (among them scholars, diplomats and merchants), translators, and teachers of these languages in the sixteenth century certainly had at their disposal a great variety of didactic materials. The pages below offer an overview on the three main categories of these types of texts ("vocabularies" or conversation books, glossaries and dictionaries, and grammar books); a discussion of some of the authors, writings, and linguistic combinations of these materials will definitely contribute to offering an insight into the complex map of foreign language learning in sixteenth-century Western Europe. ${ }^{1}$

\section{I "Vocabularies" or Conversation Books}

In the Middle Ages, there appears a type of dialogue material known as manières de langage or livres de métiers, which are model conversation books "intended for the use of travelers, merchants, and others desiring a conversational and practical rather than a thorough grammatical knowledge of French" (Simonini 1952:145). The manieres de langage are characterized by the teaching of a language through examples, and consequently, use as their basic pedagogic resource the student's capacity for imitation. The first manière was Livre des mestiers (ca.1349), written in French and Flemish by a schoolteacher of Bruges and intended for tradesmen. Years later, the Maniere de langage qui t'enseignera bien adroit parler et escrire doulz François selon l'usage et la coustume de France (1396) appeared in England, and William Caxton also published conversation books after the manières such as the bilingual Dialogues in French and English (1483), aimed at business and tradesmen.

One of the most important printing nuclei of sixteenth century Europe was Flanders, at the time an important commercial centre and a battlefield where soldiers, merchants and diplomats from various nationalities coexisted. Antwerp became one of the major centres of publication of works for the learning of vernacular

\footnotetext{
${ }^{1}$ This article does not examine teaching materials for the classical languages, which of course does not mean that they did not exist: on the contrary, all throughout Europe Latin, for example, continued to be essential in academic curricula, and it was still in effect a spoken language for many.
} 
languages, and it was in Antwerp that, for instance, Willem Vorsterman published the first phrase book to include Spanish, the Vocabulario para aprender Franches, Espannol y Flaminco (Antwerp, 1520), and a decade later also appeared in Antwerp by the same publisher the anonymous Vocabulaire en troys langues: cest assavoir François, Flameng et Espagnol - the wars in Flanders rendered the vocabularies in these three tongues highly useful. ${ }^{2}$ In 1527 the schoolmaster Noël de Berlaimont (or Barlament) published Vocabulare van nieus geordineert ende wederom gecorrigeert [...]. Vocabulaire de nouneau ordonne et derechief recorrige, a conversation book with a Flemish-French vocabulary intended for merchants and schoolchildren. ${ }^{3}$ The Vocabulare was reprinted over a hundred times in the following one hundred and sixty-two years, on most occasions anonymously under the titles of Vocabulaire, Dictionnaire, Colloquia, Dialogues, or Propos communs, and often adding other languages, thus giving way to numerous polyglot editions. ${ }^{4}$ Other polyglot manuals for traders and artisans with phrases and model dialogues were printed by Bartholomeus van Grave (Gravius), who published, among others, Vocabulaer in vier sprachen Duytsch, François, Latyn ende Spaensch (Louvain, 1551), and Vocabulaire en quatre langues Françoise, Latine, Italienne et Espagnole (Louvain, 1558), a variant of the former that substituted Italienne for Duytsch. Similar works are the Colloquia et Dictionariolum octo linguarum (Antwerp, 1558), and the Diccionario, Coloquios o Diálogos en quatro lenguas, Flamenco, Francés, Español y Italiano con las conjugaciones e instrucciones (Antwerp, 1565), another anonymous publication that appeared in the printing press of Withaye. ${ }^{5}$

\footnotetext{
2 Antwerp effectively constituted the second printing centre for books written by Spanish authors either in Latin or Spanish between 1470 and 1600; Salamanca occupied the first place, and Venice, the third (Fontainas 1965).

${ }^{3}$ The 1536 edition (Antwerp, Willem Vorsterman) is the oldest known copy of the work, whose first edition seems to date from 1527.

${ }^{4}$ The complete inventory of the editions of Berlaimont's Vocabulary can be found in Bourland (1933). See also Stein (1988).

${ }^{5}$ For more on the relevance of Bartholomeus Gravius, see Antonio Roldán Pérez and José Miguel Hernández Terrés (2002).
} 


\subsection{Glossaries and Dictionaries}

Alongside the more popular vocabularies there were polyglot dictionaries for translators, as well as polyglot glossaries appended to Colloquia or grammar manuals. The model for the latter is the Italian scholar Ambrogio da Calepio's Calepino (Reggio Emilia, 1502), a frequently reprinted Latin-Greek and Greek-Latin dictionary that in subsequent years added a number of other languages - the 1605 Basel edition of his Dictionarium undecim linguarum (Latina, Hebraica, Graeca, Gallica, Italica, Germanica, Belgica, Hispanica, Polonica, Ungarica et Anglica) featured eleven different languages. ${ }^{6}$ Furthermore, there existed nomenclatores or nominalia, which grouped words by topics instead of doing so alphabetically. The most famous nomenclatore is probably Hadrianus Junius's Nomenclator omnium rerum propria nomina variis linguis explicata indicans (Augsburg, 1555), which was so successful that it underwent various editions in the Low Countries, France and Germany combining different tongues.

Other early sixteenth century dictionaries for learners of foreign languages are Christoforo de Escobar's Dictionarium trium linguarum (Venice, 1512), in Latin, Italian and Spanish; his Vocabularium ex latino sermone in Siciliensem et hispaniensem denuo traductum (Venice, 1520), and the anonymous Quinque linguarum utilissimus vocabulista Latine Tusche, Gallice, Hyspanice \& Alemanice (Venice, 1513), with later editions in France, Germany, and Italy. Particularly for Italians interested in reading Spanish works we find Alfonso de Ulloa's Glosarios (Venice, 1553), Orazio Toscanella's Dittionario volgare et latino con la lingua Fiamminga, Spanuola et altre lingue (Venice, 1568), with Italian and Latin terms translated mainly into Spanish (although also in Flemish, French, German, Turk and modern Greek), and Christobal de las Casas's Italian-Spanish dictionary Vocabulario de las dos Lenguas Toscana y Castellana, con una introducción para la correcta pronunciación de ambas lenguas (Seville, 1570). De las Casas's is the first proper Italian-Spanish dictionary, and the only one known to have been published in the sixteenth century. It had a considerable impact upon other lexicographers of the time such as Richard Percyvall, John Minsheu and César Oudin. Published later in the century was the Recueil de dictionaires Francoys, Espaignolz et

\footnotetext{
${ }^{6}$ The list of all the editions of the Calepino dictionary and the location of the preserved items can be found in Labarre (1975).
} 
Latins. Recopilacion de Dictionarios Franceses, Españoles y Latinos (Brussels, 1599) by Henricus Hornkens, secretary of archduke Albert, the governor of the Low Countries, who a year before had married Philip II's eldest daughter. This marriage turned proficiency in Castilian into a mark of distinction and good taste at court in Brussels.

The confrontation between Spain and France from the late fifteenth to the end of the seventeenth centuries did not contribute to fostering mutual interest in the respective languages of these nations: as late as 1604 the Parisian printer of Mathieu Guillemot would produce the first Spanish-French dictionary published in France. This was the Diccionario muy copioso de la lengua española y francesa, by Jean Pallet, Henry II's physician. Among the first ItalianFrench bilingual dictionaries, we find the first edition of Francesco Alunno Del Bailo's Le ricchezze della lingua volgare (Venice, 1543), which contains a small French-Italian dictionary by Pannonius, Petit vocabulaire en langue françoise et italienne (Lyon, 1578), and Giovanni Antonio Fenice's Dictionnaire françois et italian (Morges and Paris, 1584).

\subsection{Grammar Books and Other Manuals for the Teaching of Foreign Vernacular Tongues}

Sixteenth-century grammar books of vernacular languages took as models grammars of the classical tongues, hence often explaining the vernaculars against the background or within the framework of Latin grammar. Antonio de Nebrija, author of the first grammar of the Spanish language, Gramática de la lengua castellana (Salamanca, 1492), in his prologue to Queen Isabel of Castile in fact proclaims that one of its objectives was the teaching of Castilian to foreigners as a means of spreading the official language of the nation throughout the dominions of the Spanish Crown. ${ }^{7}$ In the following decades, a number of Spanish grammars for foreign students were published in Louvain and Antwerp: Vtil, y breve institution, para aprender los principios y fundamentos de la lengua Hespañola (Louvain, 1555), in Spanish, French, and Latin; Cristóbal de Villalón's Gramatica

\footnotetext{
${ }^{7}$ Nevertheless, Nebrija's grammar was more academic than practical, and hence, of hardly any use as a learning manual for a foreigner.
} 
castellana (Antwerp, 1558), and the anonymous Gramática de la lengua vulgar de España (Louvain, 1559), written entirely in Spanish. Also in the 1550s, the Flemish language teacher in Antwerp Gabriel Meurier targeted the merchants of the port of Antwerp with his Coniugaisons, regles et instructions mout propres et necessairement requises, pour ceux qui desirent apprendre François, Italien, Espagnol, et Flamen (Antwerp, 1558), followed by Breve instruction contenante la maniere de bien prononcer \& lire le François, Italien, Espagnol, \& Flamen. In a second edition, Meurier limited his book to Spanish and French, entitling it solely in Spanish as Coniugaciones, Arte y Reglas muy propias y necessarias para los que quisieren deprender Español y Frances (Antwerp, 1568). Additionally, Meurier wrote the Vocabulaire François-Flameng (Antwerp, 1557), the Traité pour apprendre a parler en François et en Anglois (Rouen, 1563), and the Coloquios familiares moy convenientes $y$ mas prouechosos de quantos salieron fasta agora, para qualquiera qualidad de personas desseosas de saber hablar y escribir Español y Frances (Antwerp, 1568). The most popular work by Meurier was his Thresor des Sentences dorees, Dicts, Proverbes, Refrains et Dictions communs, reduicts selon l'ordre alphabeticq en quatre langues: à çavoir, Latin, Espagnol, Thiois et François, of which the printers Nicolas Lescuyer of Rouen and Jean d'Ogerolles of Lyon produced respective editions in 1577. Gabriel Meurier, who taught Spanish, Italian, French, accounting and arithmetic, published in total around twenty works about teaching that achieved great success, for it is estimated that the booksellers Plantin and J. Van Waesberghe alone sold one thousand copies of his works between 1558 and $1587 .{ }^{8}$

Even if from the first decades of the sixteenth century large numbers of polyglot works were published in the Low Countries for the learning of various vernacular tongues, it would take a few decades for the bulk of the grammars and manuals for the teaching of foreign tongues exclusively addressing the specific needs of a given linguistic community of speakers to be published elsewhere in Europe. A survey of a sample of books for foreign language instruction in other parts of Europe (namely, Spain, France, and Italy) will prove highly illuminating in terms of cultural trends and international political relations of the time. For example, in the sixteenth century, Spanish became the most popular language among the Italian high society, and hence there soon appeared the

\footnotetext{
${ }^{8}$ For more on Gabriel Meurier, see Bourland (1938).
} 
first Spanish grammar for Italians: Giovanni Mario Alessandri d'Urbino's Il paragone della lingua toscana et castigliana (Naples, 1560), written entirely in Italian. It only went to one edition due to the publication just six years later of the successful work by Giovanni Miranda Osservationi della lingua Castigliana (Venice, 1566). Indeed, Miranda's grammar, considered "one of the key, if not the key bilingual grammar in the history of the teaching of Spanish to speakers of other languages" (Breva-Claramonte 2000:720), went through ten editions in Venice in the sixteenth-century alone. As Lope Blanch points out, "since it served as a model to French, English, and German grammarians it was important well beyond Italy" (Lope Blanch 2001:96). When it comes to Spaniards wishing to learn Italian, we find the Arte muy curiosa por la qual se enseña muy de rayz, el entender, y hablar de la lengua italiana (Medina del Campo, 1596) by Francisco Trenado de Ayllón.

As mentioned above, the frequent hostilities between Spain and France determined mutual interest in their respective languages. These military and political obstacles were compounded by the fact that for sixteenth-century France and Spain, Italy was the main cultural and artistic referent, and therefore their chief source for linguistic capital. Baltasar de Sotomayor's Grammatica con reglas muy provechosas y necessarias para aprender a leer y escrivir la lengua Francesa, conferida con la Castellana (Alcalá de Henares, 1565) was the first manual for the learning of French published in Spain. Jacques Ledel's (alias Liaño) Vocabulario de los vocablos que mas comunmente se suelen usar. Puestos por orden del Abecedario, en Frances, y su declaración en Español (Alcalá de Henares, 1565), appeared as an appendix to some copies of Sotomayor's grammar. Both works were published the same year, in the same city, by the same printers. Sotomayor's book exclusively addressed his fellow countrymen, who were at the time eager to learn French after Philip II's marriage with Elizabeth of Valois in 1560. The new French queen must be held responsible for the francization of the Spanish Court of the time. It would take seventy years for the appearance in Madrid of the second edition of Grammatica Francessa (1635) by Diego de Cisneros (also known as Fray Diego de la Encarnación. ${ }^{9}$

\footnotetext{
${ }^{9}$ The first edition of this work was published in 1624 in Douai, which was at the time under the control of the Spanish Crown. Douai was of cultural, commercial and political importance from the fifteenth to the first decades of the seventeenth century.
} 
The first book for the teaching of Spanish in France was N. Charpentier's Parfaicte méthode pour entendre escrire et parler la langue espagnole (Paris, 1596), published anonymously. However, the truly influential Spanish grammar book for sixteenth-century Frenchmen was César Oudin's Grammaire et observations de la langue espagnolle, recueillies et mises en François (Paris, 1597), which underwent six editions between 1597 and 1630. Indeed, César Oudin, who worked as secretary-interpreter of Henry IV of France, is without any doubt the most important name in the teaching of Spanish in France at the end of the sixteenth and the beginning of the seventeenth centuries. ${ }^{10}$ Oudin moreover wrote Refranes y proverbios españoles traducidos en lengua francesa. Proverbes espagnols traduits en François (Paris, 1605); Tesoro de las dos lenguas francesa y española - Thresor des deux langues françoise et espagnole (Paris, ${ }^{1606)}{ }^{11}$ and the small manual of conversation Diálogos muy apacibles escritos en lengua española y traducidos al francés. Dialogues tres plaisants écrits en langue espagnole et traduits en français (Paris, 1608). At the beginning of the seventeenth century, we find Jean Saulnier's Introduction en la langue espagnolle par le moyen de la françoise (Paris, 1608), and, later on, his more elaborated Nouvelle grammaire italienne et espagnole declare par nostre langue françoise (Paris, 1635).

As for grammars composed with the purpose of teaching Italian to Frenchmen, we can single out Jean-Pierre de Mesmes's Grammaire italienne composée en francoys (Paris, 1548), and the French translation

\footnotetext{
At the time, due to administrative, military and religious needs and interests, the city gathered an important number of Spaniards, who felt the need to learn French to carry out their jobs and to communicate with the locals. Therefore, Fray Diego de la Encarnación, who then lived in a convent in the city and taught Divinity in its University, did have in mind the linguistic needs of his fellow countrymen when devising his work.

${ }^{10}$ In February 1597 Henry IV of France appointed César Oudin Secretary-Interpreter of the King, a position he held until Louis XIII, successor of Henry IV to the throne of France, granted it to Oudin's competitor Ambrosio de Salazar. César Oudin's works outlived him by many years, partly thanks to his eldest son, Antoine Oudin, who inherited the position of interpreter at Court, and who repeatedly published and corrected his father's works after his death. Antoine also published his own titles: Grammaire Française (1633), Recherches italiennes et françaises and Curiosités françaises (1640), and the Dictionnaire Italien et Français (1681).

${ }^{11}$ In 1609 another Tesoro appeared in Geneva, this time including Italian as well. Its author was the Bolognese Girolamo Vittori. César Oudin's work was entirely copied in the French and Spanish parts without acknowledging the source.
} 
of Alberto Accarigi da Cento's La Grammatica volgare di M. A. de gl' Acharsi da Cento (Venice, 1537) as La grammaire de M. Albert de la Charisi da Cento, tournee de tuscan en francois (Louvain, 1555), published by Bartholomeus Gravius. In contrast to the French interest for Italian, it would take many years for the first French grammar specifically designed for Italians to appear: this was the brief and schematic Pietro Durante's La grammatica italiana per imparare la lingua francese (Rome, 1625). Before Durante, Italians wishing to learn French could use one of the polyglot works previously mentioned, the Praecepta gallici sermonis (Strasbourg, 1607) by Philippe Garnier, or the Linguae gallicae et Italicae hortulus (Halle, 1608) by Abraham de La Faye. Durante's grammar was followed by Antoine Fabre's Grammatica italiana per imparare la lingua italiana, francese et espanola (Rome, 1626), and Giovanni Alessandro Lonchamps's Trattato della Lingua Francese e Italiana (Rome, 1638). Indeed, handbooks for the teaching of vernaculars multiplied in the seventeenth century, particularly in the case of certain languages in some countries, such as Spanish in France and French in Italy. These seventeenth-century language handbooks addressing specific audiences were mostly printed in the countries where they were meant to be sold, thus encouraging diversification in terms of centres of publication. This, however, goes beyond the temporal scope of this article.

The bibliographical review below offers a list of the sixteenthcentury printed language manuals expressly designed to teach a single language to speakers of a particular tongue. Although in the fifteenth century some books of this sort had been published, for instance, as has been mentioned, William Caxton's French-English vocabulary, the great majority of the material of this kind was to appear from the sixteenth century onwards. The following list gathers sixteenth-century grammars, dictionaries and language handbooks with the possible linguistic combinations of Italian, French, Spanish and English, the first three being the most popular modern languages in sixteenth-century Western Europe, and hence the most representative ones offering an insight into the foreign language learning map of the time. In contrast, English was generally ignored in most Western European countries until well into the eighteenth century: in sixteenth-century France, English teachers and English manuals were few, and it was only in the seventeenth century that proper handbooks such as the Alphabet 
anglais (Rouen, 1639) and the Grammaire anglaise by the London merchant Georges Mason (Paris, 1622) began to appear; in Portugal there were no specific handbooks for the teaching of English until 1700, and in Spain, not until 1759, during the reign of King Charles III, was the study of English encouraged. ${ }^{12}$ The list below is arranged first by linguistic combination and then, in two sections: one for primary sources chronologically arranged, and another for a selection of secondary sources that focus on each linguistic combination. For a general overview of Italian, French, Spanish and English as foreign languages in the Renaissance, see instead (Jekel De Jongh 1949; Simonini 1951; Caravolas 1994; Hüllen 2001).

\section{List of works}

\section{Italian \& Spanish}

\section{Primary sources $^{13}$}

Christoforo de Escobar. Dictionarium trium linguarum [Latin, Italian and Spanish] (Venice: Augustinus de Zannis de Portesio, 1512).

Christoforo de Escobar. Vocabularium ex latino sermone in Siciliensem et hispaniensem denuo traductum (Venice: Bernardinum Benalium Bergomensem, 1520).

Alfonso de Ulloa. Introdutione del Signor Alphonso di Uglioa nella quale s'insegna pronuntiare la lingua Spagnuola (Venice: Gabriel Giolito, 1553).

Giovanni Mario Alessandri d'Urbino. Il paragone della lingua toscana et castigliana (Naples: M. Cancer, 1560).

\footnotetext{
${ }^{12}$ On the low status of English as an international language in Early Modern Europe, see Cardim (1922), Burke (2004), Maclean (2009). Early English Books Online (EEBO) (url: <http:/ / eebo.chadwyck.com/home>; last accessed 15/7/2013) has been essential in carrying out the bibliographical searches for all the works printed in England. The Lexicons of Early Modern English (LEME) database has proved very helpful as well (url: <http:/ /leme.library.utoronto.ca>; last accessed 15/7/2013).

Finally, although Welsh is not within the scope of this article, it is also worthwhile to mention that, in the island of Great Britain and for its inhabitants only, EnglishWelsh dictionaries were also published during the sixteenth century, namely, William Salesbury's A dictionary in Englyshe and Welshe moche necessary to all suche Welshemen as wil spedly learne the englyshe to[n]gue (London, 1547).
}

${ }^{13}$ References to first editions only. 
Giovanni Miranda. Osservationi della lingua Castigliana (Venice: Giolitti, 1565).

Orazio Toscanella. Dittionario volgare et latino (Venice: Comin da Trino da Monferrato, 1568).

Christobal de las Casas. Vocabulario de las dos Lenguas Toscana y Castellana, con una introducción para la correcta pronunciación de ambas lenguas (Seville: Francisco Aguilar, 1570; Venice: Damian Zenaro, 1576).

Francisco Trenado de Ayllón. Arte muy curiosa por la qual se enseña muy de rayz, el entender, y hablar de la lengua italiana (Medina del Campo: Sanctiago del Canto, 1596).

\section{Secondary sources}

$\diamond$ On the teaching of Spanish as a foreign language in Renaissance Europe

Aquilino Sánchez Pérez. Historia de la enseñanza del español como lengua extranjera (Madrid: Sociedad General Española de Librería, 1992).

Manuel Breva-Claramonte. "The teaching of Spanish in 16th-century Europe." Eds . Sylvain Auroux, E. F. K. Koerner, Hans-Josef Niederehe, and Kees Versteegh. History of the Language Sciences: An International Handbook on the Evolution of the Study of Language from the Beginnings to the Present (Berlin-New York: Walter de Gruyter, 2000: 717-723).

$\diamond$ On the teaching of Italian in Spain and of Spanish in Italy

Anna Maria Gallina. Contributi alla storia della lessicografia italo-spagnola dei secoli XVI e XVII (Firenze: L. S. Olschki, 1959)

Juan M. Lope Blanch. "Las Osservationi de Giovanni Miranda (Venecia, 1566)." Eds. E. F. K. Koerner and Hans-Josef Niederehe. History of linguistics in Spain/Historia de la lingü̈stica en España (Amsterdam: Benjamins, 2001: 96-106).

$\diamond$ On the teaching of Spanish in the sixteenth-century

Antonio Roldán. "Motivaciones para el estudio del español en las gramáticas del siglo XVI." Revista de Filología Española 58 (1976): 201-229.

\section{Italian \& French}

\section{Primary sources}

Francesco Alunno Del Bailo. Le ricchezze della lingua volgare (Venice: Aldo Manuzio, 1543). 
(8) ederi 23 (2013)

Jean-Pierre de Mesmes. Grammaire italienne, composée en Françoys (Paris: Estienne Groulleau or Gilles Corrozet, 1548).

La grammatical volgare di M. Alberto de gl'Acharisi Dacento [...] tournée de Tuscan en François (Leuven: Bartholomeus Gravius, 1555).

Pannonius. Petit vocabulaire en langue françoise et italienne (Lyon: Roger de Brey, 1578).

Giovanni Antonio Fenice. Dictionnaire françois et italian (Morges: Jean Le Preux for the Parisian editors Jacques Du Puys and Nicolas Nivelle, 1584; Geneva, Pierre Canal, 1598).

\section{Secondary sources}

$\diamond$ On the teaching of French as a foreign tongue in Renaissance Europe

Jan De Clercq, Nico Lioce, and Pierre Swiggers, eds. Grammaire et enseignement du français, 1500-1700 (Leuven: Peeters, 2000).

$\diamond$ On the teaching of French in Italy

Nadia Minerva and Carla Pellandra. Insegnare il francese in Italia: repertorio analitico di manuali pubblicati dal 1625 al 1860 (Bologna: CLUEB, 1997).

$\diamond$ On the teaching of Italian in Renaissance Europe

Claudio Marazzini. "The teaching of Italian in 15th- and 16th-century Europe." Eds. Sylvain Auroux, E. F. K. Koerner, Hans-Josef Niederehe, and Kees Versteegh. History of the Language Sciences: An International Handbook on the Evolution of the Study of Language from the Beginnings to the Present (Berlin-New York: Walter de Gruyter, 2000: 699-705).

$\diamond$ Particularly for the teaching of Italian in France

Nicole Bingen. "Sources et filiations de la 'Grammaire Italienne' de JeanPierre de Mesmes." Bibliothèque d'Humanisme et Renaissance 3/46 (1984): 633-638.

Nicole Bingen. Le Maître italien (1510-1660): bibliographie des ouvrages d'enseignement de la langue italienne destinés au public de langue française, suivie d'un répertoire des ouvrages bilingues imprimés dans les pays de langue française (Brussels: É. Van Balberghe, 1987).

Emile Picot. Les italiens en France au XVIe siècle (Rome: Vecchiarelli editore, 1995). 


\section{Spanish \& French}

\section{Primary sources}

Baltasar de Sotomayor. Grammatica con reglas muy provechosas y necessarias para aprender a leer y escrivir la lengua Francesa, conferida con la Castellana (Alcalá de Henares: Pedro de Robles y Francisco de Cormellas, 1565).

Jacques Ledel (alias Liaño). Vocabulario de los vocablos que mas comunmente se suelen usar. Puestos por orden del Abecedario, en Frances, y su declaración en Español (Alcalá de Henares: Pedro de Robles \& Francisco de Cornellas, 1565). This work was published as an appendix to some copies of Sotomayor's grammar.

Gabriel Meurier. Coniugaciones, Arte y Reglas muy propias y necessarias para los que quisieren deprender Español y Frances (Antwerp: Jan van Waesberghe, 1568).

Gabriel Meurier. Coloquios familiares moy convenientes y mas prouechosos de quantos salieron fasta agora, para qualquiera qualidad de personas desseosas de saber hablar y escribir Español y Frances (Antwerp: Jan van Waesberghe, 1568).

N. Charpentier (published anonymously). Parfaicte méthode poor entendre escrire et parler la langue espagnole (Paris: Matthieu Guillemot, 1596).

César Oudin. Grammaire et observations de la langue espagnolle, recueillies et mises en François (Paris: Marc Orry, 1597).

Henricus Hornkens. Recueil de dictionaires Francoys, Espaignolz et Latins. Recopilacion de Dictionarios Franceses, Españoles y Latinos (Brussels: Rutger Velpius, 1599).

\section{Secondary sources}

\section{On the teaching of French in Spain}

Hans-Josef Niederehe. "Les dictionnaires franco-espagnols jusqu'en 180o." Histoire Épistémologie Langage 9/ 2 (1987): 13-26.

J. Fidel Corcuera Manso and Antonio Gaspar Galán. La lengua francesa en España en el siglo XVI: estudio y edición del Vocabulario de los vocablos de Jacques de Liaño, Alcalá de Henares, 1565 (Zaragoza: Prensas Universitarias de Zaragoza, 1999).

Brigitte Lépinette. El francés y el español en contraste y en contacto, siglos XVXVII: estudios de historiografia lingüística: lexicografia, gramática, traducción (Valencia: Universitat de València, 2001). 
Denise Fischer, Juan F. García Bascunana, and María Trinidad Gómez. Repertorio de gramáticas y manuales para la enseñanza del francés en España (1565-1940) (Barcelona: PPU, 2004).

Gonzalo Suárez Gómez. La enseñanza del francés en España hasta 1850: ¿Con qué libros aprendían francés los españoles? (Barcelona: PPU, 2008).

$\diamond$ On the teaching of Spanish in Renaissance France

Brigitte Lepinette. "La Lexicographie franco-espagnole avant le Tesoro de las dos lenguas de Cesar Oudin (1606)." Travaux de Linguistique et de Philologie 28 (1990): 317-342.

Sabina Collet Sedola. "Gramáticos y gramáticas: España en Francia (16001650)." Ignacio Arellano, et al. eds., Studia aurea: Actas del III Congreso de la AISO, Toulouse, 1993 (Pamplona: GRISO; Toulouse: LEMSO, 1996, 161-168).

\section{English \& French}

\section{Primary sources}

Alexander Barclay. Here begynneth the introductory to wryte, and to pronounce frenche compyled by Alexander Barcley (London: Robert Coplande, 1521).

Pierre Valence. Introductions in Frensshe (London: W. de Worde, 1528?).

John Palsgrave. Lesclarcissement de la langue francoyse (London: Richard Pynson, ca. 1524, finished by Johan Haukyns, 1530).

Giles Duwes (or Du Wés). An introductorie for to lerne to rede, to pronounce, and to speake Frenche (London: Thomas Godfray, 1533?).

Pierre Du Ploiche. A treatise in English and Frenche right necessary and proffitable for al young children (London: Rychard Grafton, 1551).

Gabriel Meurier. Traité pour apprendre a parler en François et en Anglois (Rouen: Bonav. Belis, 1563).

Claudius Hollyband. The French Littelton A most easie, perfect and absolute vvay to learne the frenche tongue (London: Thomas Vautroullier, 1566).

L[ucas?]. H[arrison?]. A Dictionarie French and English (London: Henry Bynneman, 1571).

John Rastell. The expositions of the termes of the lawes of Englande with diuers propre rules and principles of the lawe, aswell oute of the bookes of master Litleton, as of other. Gathered both in Frenche and English (London: Richardi Tottel, 1572). 
Claudius Hollyband (Claude De Sainliens or Desainliens). The French schoolemaister wherin is most plainlie shewed, the true and most perfect way of pronouncinge of the French tongue, without any helpe of maister or teacher (London: William How for Abraham Veale, 1573).

John Baret. An aluearie or triple dictionarie in Englishe, Latin, and French: very profitable for all such as be desirous of any of those three languages (London: Henry Denham, 1574).

G. Ledoyen de la Pichonnaye. A playne treatise to learne in a short space the Frenche tongue deuided in twoo bookes (London: Henry Denham, 1576).

John Baret. An aluearie or quadruple dictionarie containing foure sundrie tongues: namelie, English, Latine, Greeke, and French (London: Henry Denham, 1580).

Jacques Bellot. The Englishe Scholemaister. Conteyning many profitable preceptes for the naturall borne french men, and other straungers that haue their French tongue, to attayne the true pronouncing of the Englishe tongue (London: Thomas Purfoote, 1580).

Claudius Hollyband. De pronuntiatione linguae Gallicae libri duo (London, Thomas Vautrollerius, 1580).

Claudius Hollyband. The treasurie of the French tong teaching the waye to varie all sortes of verbes (London: Henrie Bynneman, 1580).

Claudius Hollyband. A treatise for declining of verbes, which may be called the second chiefest worke of the french tongue (London: Thomas Vautrollier, 1580).

Jacques Bellot. The French methode wherein is contained a perfite order of grammer for the French tongue. Made and set forth by Iames Bellot, gentleman of Caen in Normandy (London: Robert Robinson, 1588).

De la Mothe. The French alphabet (London: Richard Field, 1592).

John Eliot. Ortho-epia Gallica. Eliots fruits for the French (London: Richard Field for John Wolfe, 1593).

Claudius Hollyband. A dictionarie French and English published for the benefite of the studious in that language (London: Thomas Orwin, 1593).

\section{Secondary sources}

\section{$\diamond$ On the teaching of French in Medieval England}

Jean Gessler. La manière de langage qui enseigne à bien parler et écrire le français: modèles de conversations composés en Angleterre à la fin du XIVe siècle (Bruxelles: Paris: L'Édition universelle, E. Droz, 1934: 23-29). 
W. Rothwell. "The Teaching of French in Medieval England." The Modern Language Review 1/63 (1968):37-46.

$\diamond$ On the teaching of French in early modern England

Kathleen Rebillon Lambley. The teaching and cultivation of the French language in England during Tudor and Stuart times (Manchester, 1920).

Douglas A. Kibbee. For to Speke Frenche Trewely: The French Language in England, 1000-1600: Its Status, Description and Instruction (Amsterdam/Philadelphia: John Benjamins, 1991).

Gabriele Stein. John Palsgrave as Renaissance Linguist: A Pioneer in Vernacular Language Description (Oxford: Clarendon Press, 1997).

\section{English \& Italian}

\section{Primary sources}

William Thomas. Principal rules of the Italian grammer with a dictionarie for the better vnderstandyng of Boccace, Petrarcha, and Dante (London: Thomas Berthelet, 1550).

David Rowland, translator. A comfortable ayde for Schollers, full of variety of sentences, gathered out of an Italian author, (intituled in that tongue, Specchio de la lingua Latina) (London: H. Wykes, 1568).

Henry Granthan, translator. An Italian grammer written in Latin by Scipio Lentulo a Neapolitane: and turned into Englishe by Henry Granthan (London: Thomas Vautrollier, 1575).

John Florio. Florio his firste fruites which yeelde familiar speech, merie prouerbes, wittie sentences, and golden sayings. Also a perfect induction to the Italian, and English tongues (London: Thomas Dawson, 1578).

Claudius Hollyband. Campo di fior or else The flourie field of foure languages of M. Claudius Desainliens, aliâs Holiband: for the furtherance of the learners of the Latine, French, English, but chieflie of the Italian tongue (London: Thomas Vautrollier, 1583).

John Florio. Florios second frutes to be gathered of twelue trees, of diuers but delightsome tastes to the tongues of Italians and Englishmen. To which is annexed his Gardine of recreation yeelding six thousand Italian prouerbs (London: T. Orwin, 1591).

Claudius Hollyband. The Italian Schoole-maister: contayning rules for the perfect pronouncing of th'italian tongue (London: Thomas Purfoot, 1597). 
John Florio. A vvorlde of wordes, or Most copious, and exact dictionarie in Italian and English, collected by Iohn Florio (London: Arnold Hatfield, 1598).

\section{Secondary sources}

$\diamond$ On the teaching of Italian in England

Rinaldo C. Simonini, Jr. "Italian-English Language Books of the Renaissance." Romanic Review 4/ 42 (1951): 241-244.

Rinaldo C. Simonini, Jr. "The Italian Pedagogy of Claudius Hollyband." Studies in Philology 49 (1952): 144-154.

Clifford Chalmers Huffman. Elizabethan impressions: John Wolfe and his press (New York: AMS Press, 1988).

Warren Boutcher. "'A French Dexterity, \& an Italian Confidence': New Documents on John Florio, Learned Strangers and Protestant Humanist Study of Modern Languages in Renaissance England from c. 1547 to c. 1625." Reformation 2 (1997): 39-109.

Jason Lawrence. "Who the devil taught thee so much Italian?": Italian language learning and literary imitation in early modern England (Manchester: Manchester University Press, 2005).

\section{English \& Spanish}

\section{Primary sources}

Anonymous. The boke of Englysshe, and Spanysshe and A very profitable boke to lerne the maner of redyng, writing, E speaking English $\mathcal{E}$ Spanish (London: Robert Wyer, 1554?).

Antonio del Corro. Reglas gramaticales para aprender la lengua espanola y francesa (Oxford: Joseph Barnes, 1586)

John Thorius, translator. The Spanish grammer voith certeine rules teaching both the Spanish and French tongues (London: John Wolfe, 1590).

Richard Percyvall. Bibliotheca Hispanica Containing a grammar; with a dictionarie in Spanish, English, and Latine (London: John Jackson, 1591).

William Stepney. The Spanish schoole-maister (London: Richard Field, 1591).

Richard Percyvall and John Minsheu. A dictionarie in Spanish and English (London: Edm. Bollifant, 1599).

Richard Percyvall and John Minsheu. A Spanish gramar (London: Edm. Bollifant, 1599). 


\section{Secondary sources}

Sofía Martín-Gamero. La enseñanza del inglés en España: desde la Edad Media al siglo XIX (Madrid: Gredos, 1961).

Roger J. Steiner. Two Centuries of Spanish and English Bilingual Lexicography (1590-1800) (The Hague-Paris: Mouton, 1970).

Patricia Shaw. "Noticias y conocimientos acerca de la lengua española en la Inglaterra del siglo XVII." Estudios ofrecidos a Emilio Alarcos Llorach con motivo de sus XXV años de docencia en la Universidad de Oviedo, Vol. 4 (Oviedo: Servicio de Publicaciones Universidad de Oviedo, 1976-1983: 325-348).

Heberto H. Hernández Urdaneta. Dictionaries in Spanish and English from 1554 to 1740: Their Structure and Development (Soria: Diputación de Soria, 2010).

\section{References}

Bischoff, Bernhard 1961. "The Study of Foreign Languages in the Middle Ages." Speculum 2/36: 209-224.

Bourland, Caroline B. 1933. "The Spanish Schoole-Master and the Polyglot Derivatives of Noël de Berlaimont's Vocabulare." Revue Hispanique: Recueil Consacré á l'Étude des Langues, des Littératures et de l'Histoire des Pays Castillans, Catalans et Portugais 1/81: 283-318.

Bourland, Caroline B. 1938. "Algo sobre Gabriel Meurier: Maestro de Español de Amberes (1521-1597?)." Hispanic Reviezv 2/6: 139-152.

Brefeld, Josephine 1994. A Guidebook for the Jerusalem Pilgrimage in the Late Middle Ages. Hilversum: Verloren.

Burke, Peter 2004. Languages and Communities in Early Modern Europe. Cambridge: Cambridge University Press.

Caravolas, Jean-Antoine 1994. La didactique des langues. Précis d'histoire I: 1450-1700. Montréal: Presses de L’Université de Montréal \& Tübingen: G. Narr.

Cardim, Luis 1922. Some Notes on the Portuguese-English and EnglishPortuguese Grammars to 1830. Porto: Tipografia de "A Tribuna."

Fontainas, Jean Peeters 1965. Bibliographie des impressions espagnoles des PaysBas méridionaux. Nieuwkoop: B. de Graaf.

Hüllen, Werner 2001. "Reflections on Language in the Renaissance." Eds. Martin Haspelmath et al. Language Typology and Language Universals. An International Handbook. Berlin: Walter de Gruyter: 210-222. 
Jekel De Jongh, William Frederick 1949. Western Language Manuals of the Renaissance. Albuquerque: University of New Mexico Press.

Kibbee, Douglas A. 200o. "Language Instruction for Western European Travelers." Eds. John Block Friedman et al. Trade, Travel, and Exploration in the Middle Ages: An Encyclopedia. New York-London: Garland: 330-331.

Labarre, Albert 1975. Bibliographie du Dictionnaire d'Ambrogio Calepino 15021779. Baden-Baden: Valentin Koerner.

Maclean, Ian 2009. "English Books on the Continent, 1570-1630." Learning and the Market Place: Essays in the History of the Early Modern Book. LeidenBoston: Brill: 339-370.

Penzl, Herbert 1984. "'Gimer min ros': How German Was Taught in the Ninth and Eleventh Centuries." The German Quarterly 3/57: 392-401.

Roldán Pérez, Antonio and José Miguel Hernández Terrés 2002. "Labor editora de Bartolomé Gravio." Eds. Miguel Ángel Esparza Torres et al. Actas del III Congreso Internacional de la Sociedad Española de Historiografia Lingüística. Hamburg: Helmut Buske Verlag: 415-430.

Simonini Jr., R. C. 1951. "The Genesis of Modern Foreign Language Teaching." The Modern Language Journal 3/35: 179-186.

Stein, Gabriele 1988. "The Emerging Role of English in the Dictionaries of Renaissance Europe." Folia Linguiistica Historica 9: 29-138.

Suárez Gómez, Gonzalo 2008. La enseñanza del francés en España hasta 1850: ¿Con qué libros aprendían francés los españoles? Barcelona: PPU.

How to cite this note:

Sumillera, Rocío G. "Sixteenth-Century Italian, French, Spanish and English Language Learning Material. A Bibliographical Study." SEDERI 23 (2013): 139158.

Author's contact: sumillera@ugr.es

Submission: 26/o9/2012 - Acceptance: 08/01/2013 


\title{
Michael Dobson. 2011 \\ Shakespeare and Amateur Performance: A Cultural History Cambridge: Cambridge University Press
}

\author{
José A. Pérez Díez \\ The Shakespeare Institute, University of Birmingham
}

The wide gap between professional and amateur theatre has traditionally been regarded as a non-negotiable division between two mutually exclusive remits. But, as Michael Dobson suggests in the introduction to this monograph, the boundary between the two over the last few centuries has not only been permeable, but also blurred and difficult to trace. Actors with no formal training continue to access the profession, and professional practitioners regularly take part in unpaid productions when remunerated jobs are unavailable. As the author states, "it has never been easy to distinguish between a young waiter with a serious amateur interest in the theatre and an apprentice actor with a part-time job in catering" (7). If the boundary is difficult to determine with precision in our own time, it seems almost impossible to establish this distinction when we consider theatre practice before the nineteenth century. As Dobson shrewdly observes, "William Shakespeare was not what we would call an amateur, certainly, but as the liveried nominal servant of an aristocrat and then a king he was not exactly what we would now describe as professional either" (5).

Scholars have dedicated more than considerable attention to the performance history of Shakespeare's plays in the commercial theatre since they premiered. Major critical editions of the plays now regularly include serious consideration of performance issues based on professional practice, and the work of experts in theatre studies over the past few decades has been especially fruitful in the investigation of Shakespearian performance. However, few of them have tried to add non-professional theatre to their scholarship, 
perhaps assuming that amateur productions are just not as interesting to analyse, or as worthy of serious critical scrutiny. Only in recent times some members of the scholarly community have managed to actively challenge this preconception. Major essays by leading academics such as Andrew Hartley (2012) and Jeremy Lopez (2012) have focused some scholarly interest on the neglected work of non-professional theatre groups, vindicating their work as part of the wider performance context of these plays.

A token of this increasing scholarly interest that amateur Shakespeare is receiving is the fact that during the 2012 meeting of the Shakespeare Association of America in Boston no less than two seminars were devoted to this topic. Andrew Hartley convened "Shakespeare on the Campus Stage," while the author of the present monograph led "Voluntary Sector Shakespeare" with contributions from a group of eminent scholars including Ton Hoenselaars, Kiki Lindell, Siobhan Keenan, Isabelle Schwartz-Gastine, and Clara Calvo.

With this book Michael Dobson has made a major contribution to the study of the amateur phenomenon specifically applied to Shakespearian performance. It is an energetic reaction to the "persistent inattention among scholars to the importance of nonprofessional activity within the reception of Shakespeare in particular" (10), and it is grounded on an incontrovertible fact: there have been more amateur productions of Shakespeare over the past four centuries than professional enterprises.

Dobson has chosen to limit the scope of his study to cover only "amateur performances given in English," primarily performed in "Britain and Ireland and, to a lesser extent, North America" (9), conceding that a comprehensive survey of non-professional productions of Shakespeare is an impossible task, given that most archival material is accessible only in very partial shape, often as anecdotal oral evidence, or as collections of pictures, recordings, and other memorabilia kept in private hands, or has simply not survived. While some performing groups keep comprehensive archives, most have never been concerned with preserving their work for posterity.

The decision to focus primarily on the United Kingdom is immediately justifiable by the vibrancy of non-professional theatre in the country. Participation in amateur dramatic groups and 
societies is a time-honoured tradition in Britain, where groups that sometimes exhibit great technical and managerial sophistication have been active for many decades, or even centuries. Their repertory spans from classical drama to full-blown Broadway musicals, charity recitals, concerts or revues, as well as the latest theatrical hits of the commercial London theatre, quickly transferred to the amateur stage by paying expensive performance rights to the playwright's agents. Shakespeare's plays are regularly included in this repertory.

The United Kingdom also saw the most vigorous effort to engage more effectively with their neighbouring amateur practitioners made by a major professional company: the Royal Shakespeare Company launched in early 2011 the RSC Open Stages festival to promote the cultural transaction between professional and amateur practitioners, offering free workshops with professionals, as well as the promotion and support of amateur productions of Shakespearian plays and adaptations through a network of regional hubs all over the country, including the opportunity to perform on the stages of the RSC in Stratford in a series of national showcases that put an end to the project in mid-2012. Michael Dobson, now director of the Shakespeare Institute in Stratford, took part in the project as its main research associate.

Given the impossibility of being all-inclusive, Dobson has chosen to structure the book as a collection of more or less independent sections devoted to a series of meaningful and illustrative case studies: domestic, civic, expatriate, and outdoor Shakespeares.

The first section, "Shakespeare in private," traces the emergence of "private theatricals" from the production of a conflated Henry IV staged in 1623 in Sir Edward Dering's country house in Surrenden, Kent, to the production of Dryden's adaptation of Antony and Cleopatra, All for Love, at Blenheim Palace staged by the Duke of Marlborough's grandchildren, and other productions at country houses in the eighteenth century. The chapter concludes with a comprehensive analysis of "the great Kilkenny theatricals of $1802-$ 19 " (46), completing the three movements that sketch the development of non-professional Shakespearian performance in the two centuries following the death of their author. 
The second covers the emergence of the amateur dramatic society as we understand it today, negotiating the considerable public opposition to private and non-professional productions outside the theatres with royal patent towards the end of the eighteenth and the beginning of the nineteenth centuries, when Shakespeare was identified "as the property of the legitimate public Theatres Royal" (69). The study continues through the important creation of the Stockport Garrick Society in the early twentieth century, and the establishment of dedicated theatres for amateur dramatics all over Britain.

The third section traces the fortunes of amateur theatricals performed by British expatriates in various places and under very different circumstances, ranging from diplomatic missions to countries in the British Empire, to Shakespeare productions given by British prisoners of war imprisoned by the Axis during the Second World War. This study includes the productions at the Stalag VIIIB Lamsdorf concentration camp in Silesia in 1943, where a young Denholm Elliott alternated Eliza Doolittle in Shaw's Pygmalion with Viola in Twelfth Night.

The final chapter presents an account of the particularly British preference for amateur Shakespeare productions in the open air that are especially popular in the summer, when actors regularly have to battle against the unpredictability of the British weather.

With his characteristically elegant and formidably engaging tone, Michael Dobson offers an important book, hopefully a pioneering work in a thriving field of research. The lives and stories presented on its pages pay tribute to many generations of ordinary people who took to the stage etymologically out of love, and who, with varying degrees of success, demonstrated that the possibility of offering compelling and skilled theatrical performances is not the sole patrimony of professional practitioners. And in this celebration the author shows the way for other scholars to continue to engage with non-professional theatre as a cultural phenomenon worthy of further enquiry.

\section{References}

Hartley, Andrew James 2012. "A Dream of Campus." Shakespeare Survey. 65. Cambridge: Cambridge University Press: 194-210. Shakespeare Survey 


$$
\text { (a) ederi 23 (2013) }
$$

Online. <url: http://dx.doi.org/10.1017/SSO9781139170000.016>. Last accessed 30 July 2013

Jeremy Lopez 2012. "The seeds of time: student theatre and the drama of Shakespeare's contemporaries;" "Performances of early modern drama at academic institutions since 1909;" and "Performances of early modern plays by amateur and student groups since 1887." Eds. Pascale Aebischer and Kathryn Prince. Performing Early Modern Drama Today. Oxford: University Press: 35-52, 218-227.

How to cite this review:

Pérez Díez, José A. Review of Michael Dobson. 2011. Shakespeare and Amateur Performance: A Cultural History (Cambridge: Cambridge University Press). SEDERI 23 (2013): 161-165.

Author's contact: jap942@bham.ac.uk 


\title{
Angel-Luis Pujante and Keith Gregor, eds. 2010. Hamlet en España: Las cuatro versiones neoclásicas. Salamanca and Murcia: Ediciones Universidad de Salamanca and Editum.
}

\author{
Keith Gregor and Angel-Luis Pujante, eds. 2011. \\ Macbeth en España: Las versiones neoclásicas. \\ Murcia: Editum.
}

\author{
Juan Antonio Prieto Pablos \\ Universidad de Sevilla
}

The two books reviewed here can be considered as two aspects of one enterprise, jointly carried out by Angel-Luis Pujante and Keith Gregor. These volumes are also the most recent outcomes of a longer and very fruitful research project. Its origins can be found in the research carried out by Angel-Luis Pujante for his translations of Shakespeare's plays. Intended originally to substantiate his translations, his research eventually became a major, independent branch that centred on the compilation of material concerning the history of the reception of Shakespeare in Spain - a branch that broadened even further when it connected with the international project that sought the same goals in several countries in continental Europe. The conference on "Shakespeare in the New Europe," held in Sofia (Bulgaria) in 1993, can be considered one of the starting points. Pujante - with the help of colleagues from the University of Murcia - contributed to its development with a conference held in 1999, and some of these papers were published under the title Four Hundred Years of Shakespeare in Europe. For scholars in Spain the work required the collective effort of a team of academics, mostly located at the University of Murcia, whose research has produced outstanding results. A compilation of critical reports on Shakespeare from 1764 to 1916, carried out by Pujante and Laura Campillo, was published in 2007 under the title Shakespeare en España. This book 
mapped out the full scope of criticism on Shakespeare and his work. Keith Gregor also offered a thorough account of Shakespeare's presence in Spanish theatre from 1772 to the present, in an essay published in 2010. Now Pujante and Gregor have turned their attention to the adaptations, versions, and translations of two of Shakespeare's plays, Hamlet and Macbeth, in late eighteenth- and early-nineteenth century Spain. In scope their aims may seem to be much more limited: the neoclassical period is just a small portion of the map in the history of Shakespeare reception in Spain, and perhaps not the most appealing one. However, the volumes being reviewed address a rather neglected area, and offer interesting insights into the various ways Shakespeare has been re-shaped, and the motivations - both aesthetic and ideological - behind them. And it is to be hoped that their work continues with further editions of other plays by Shakespeare.

For the reader of these two volumes the most outstanding features of the versions compiled by Pujante and Gregor are twofold. On the one hand, the way in which these plays confirm the almost hegemonic influence exerted by neoclassical rules in the eighteenth century, which made France a veritable "aduana cultural" (Campillo 2007: xxi; Pujante and Gregor 2010:15) for theatrical productions in virtually the whole continent; and on the other, the fact that Shakespeare's Hamlet and Macbeth were known in Spain not through translations of the original in English, but from French versions written by someone who had never read Shakespeare's plays. The word "version," though used by the editors in the titles of their volumes, is perhaps not fully expressive of the extent of the transformation suffered by Shakespeare's plays, and in their analysis they suitably resort to an alternative term, "refundición," to refer to what happened. From a present-day perspective, based on the utmost respect to the original, these refundiciones may seem perverted; yet they show how Shakespeare never was (perhaps still is not) a stable figure in western literary history.

A great deal of the responsibility for the dissemination of this distorted image of Shakespeare must be attributed to one single person: Jean-François Ducis. Voltaire can be held responsible for laying the grounds for the dismissal of Shakespeare as a rough dramatist in France, and Moratín for doing the same in Spain (see Pujante and Campillo 2007:xxi); but the brunt falls on Ducis - a 
playwright whom Pujante and Gregor brand as "mediocre" (2010:17) yet who held a monopoly on Shakespeare for the French stage - and, via translations, the Spanish - for several decades. Ducis's own versions of Shakespeare's plays were based on the synoptic adaptations created by Pierre-Antoine de la Place (Pujante and Gregor 2010:18). For his refundiciones he further reshaped la Place's plots so that they could fit within the patterns of neoclassicism; and to fulfil this plan he clipped and invented, reinterpreted events and renamed characters, to the extent that Shakespeare's original Hamlet and Macbeth are barely recognizable under his neoclassical coat of varnish. The story of these transformations is outlined in great detail and clarity in the introduction to each volume.

When faced with the prospect of the French re-formulation of Shakespeare's plays, it may come as a surprise to find that, in providing versions of Hamlet and Macbeth for the Spanish stage, the translators were quite faithful to Ducis's original. This is no doubt further evidence of the subordination of Spanish drama to the French at the time. The freedom of the translators was limited to the choice of verse patterns (from French alexandrines to Spanish hendecasyllabic lines) and, occasionally, to the change of names for some of the characters (for example, from Shakespeare's Lady Macbeth to Ducis's Frédegonde to García Suelto's Demetria) or some minor lexical variations motivated by the need to suit the plays to current political conditions. All this is explained with great clarity by Pujante and Gregor in their introductions to each of the volumes, and can be inferred as well from the versions presented here. The first offers all four known translations of Hamlet. According to the editors, two of them were based on Ducis's 1770 version, the remaining two on a revised text, published in 1809. Of these, only the earliest, attributed to Ramón de la Cruz, was printed (in 1900; see Pujante and Gregor 2010:16); the rest (an anonymous translation held in Santander and those produced by Antonio de Saviñón and José $\mathrm{M}^{\mathrm{a}}$ de Carnerero) were hitherto only available in manuscript. Their significance for Shakespearian and Spanish theatrical history, however, is quite limited, considering that they were never used for theatrical productions. Yet, as Pujante and Gregor argue, they still serve as illustrations of the way in which "el mito de Hamlet [...] contribuyó a la recepción de Shakespeare en España y en el conjunto de Europa" (2010:25) for over fifty years. The same paradigm applies to Macbeth. Again, Ducis served as the basis, via his version of 1790 , 
for three Spanish translations: one, written by Teodoro de la Calle, is lost; the remaining two are presented here, and one of them (Antonio de Saviñón's) is made available in print for the first time. The author of the third translation, Manuel García Suelto, claimed that he wished to present it in a style that would be "claro y energético sin bajeza ni afectación, y una versificación fácil y armoniosa," and the editors concede that he succeeded in this endeavour (Gregor and Pujante 2011:28). The same can be said about all the other versions, in general, and readers who wish to ascertain how Shakespeare was reshaped in late eighteenth-century Spain will no doubt enjoy reading them here.

The contents of both volumes are arranged in very much the same manner. The first, featuring the Hamlet translations, opens with a brief but very illuminating introduction (13-41) which outlines the history of these translations, from Ducis to the manuscripts (seemingly intended for performance) to their printed format. Since Ducis is the main source, a fair proportion of the introduction focuses on the variations he introduced. The second part of the introduction shifts to the Spanish translations, and analyses both the formats (verse, rhyme) chosen by each of the translators and the changes they made to Ducis's own version. Most enlightening is the way the editors combine textual analysis with consideration on the political circumstances that seemingly determined certain - albeit minor - alterations in lexicon and plot. So, for example, they argue that Saviñon's version was in part influenced by his support for the liberal "Cortes de Cádiz", whereas Carnerero's was determined by his deep conservatism (Pujante and Gregor 2010:37-38). The volume then presents all four translations, in chronological order, followed by a section with "Notas complementarias" on the different copies used for their collation (345-350) and on the authorship of the translation attributed to Ramón de la Cruz (351-353). The fourth section comprises two appendixes, with the first Spanish translation from an original in English (Moratín's) and a table listing all Spanish versions of Hamlet, from 1772 (the translation attributed to de la Cruz) to 2000 (by Alfonso López and Borrego for Edimat), compiled by Laura Campillo. The volume ends with a brief list of works cited.

The volume on Macbeth features the same sections: the introduction (11-35) has an account of the pains it took Ducis to make Shakespeare's tragedy palatable and "artísticamente 
convincente" according to neoclassical tastes yet with the necessary "verité de sentiment" (Gregor and Pujante 2011:17, 18) - a greater challenge to verisimilitude than Hamlet, which "only" had the problem of the supernatural apparition of Hamlet's father: for Macbeth Ducis had to cope with the presence of the witches and with the bloody excesses of the Scottish tyrant. Then the introduction analyses the two extant Spanish translations. The third section is here limited to a mere two-paragraph note on the two manuscript versions of Saviñón's Macbeth and García Suelto's printed edition (219); possibly just enough but otherwise a too succinct account of the differences between Saviñón's first - and seemingly poorer - and second manuscript copies. An appendix in the fourth section includes, again, the first translation of Macbeth based on an English version; this was undertaken by José García de Villalta and, attesting to the prevalence of neoclassical tastes at the time, it proved a "fracaso mayúsculo" on the stage (Gregor and Pujante 2011:12), yet the text provides a substantial basis for any reader who wishes to compare it with the two neoclassical versions. A second appendix is drawn from Laura Campillo's table of versions of Macbeth made in Spain from 1803 (Teodoro de la Calle's) to 2009 (Miralles Torner's). The volume concludes with a list of works cited.

If in their content arrangement these two volumes are very similar, in their printed format there are some differences to note. Hamlet en España has been published by Ediciones Universidad de Salamanca in collaboration with Editum (the publisher for the University of Murcia) on cream-coloured paper, which offers the visual impression of a good-quality print; 11-point font sizes, which may be a bit too small for some readers but means that each page contains sizeable portions of the text; and, most importantly, page headings which facilitate the location of each page within its corresponding section. Macbeth en España, on the other hand, published only by Editum, has a more austere format, with twelvepoint fonts on white paper and no page headings. The printers' choice of Ibarra Real as the font for the neoclassical versions is commendable in terms of the recuperation of national heritage print types, but its presentation on the page clashes somewhat with the bare formatting of the page itself. This may just be a personal impression, but these formatting choices make the first volume more attractive and readable than the second. 
In all, the merits of these two volumes are considerable. Theatre historians and Shakespeare scholars will find here a unique opportunity to read texts hitherto not available and to learn about a rather neglected period in the history of Shakespeare's reception in Spain.

\section{References}

Gregor, Keith 2010. Shakespeare in the Spanish Theatre: 1772 to the Present. New York: Continuum.

Hattaway, Michael et al. eds. 1994. Shakespeare in the New Europe. Sheffield: Sheffield Academic Press.

Pujante, Angel-Luis and Ton Hoenselaars eds. 2003. Four Hundred Years of Shakespeare in Europe. London: Associated University Presses.

Pujante, Angel-Luis and Laura Campillo eds. 2007. Shakespeare en España: Textos 1764-1916. Granada y Murcia: Publicaciones de la Universidad de Granada and Editum.

How to cite this review:

Prieto Pablos, Juan Antonio Review of Angel-Luis Pujante and Keith Gregor, eds. 2010. Hamlet en España: Las cuatro versiones neoclásicas (Salamanca and Murcia: Ediciones Universidad de Salamanca and Editum); and of Keith Gregor and Angel-Luis Pujante, eds. 2011. Macbeth en España: Las versiones neoclásicas (Murcia: Editum). SEDERI 23 (2013): 167-172.

Author's contact: ppablos@us.es 


\section{Margarete Rubik ed. 2011 \\ Aphra Behn and Her Female Successors. Wien: Lit Verlag}

Sonia Villegas López

Universidad de Huelva

\section{Re-Reading Aphra: Experimentations with Genre and Gender from the Restoration to the Present}

Aphra Behn's figure and her lasting influence in the production of a huge number of seventeenth-century and more recent authors is the leitmotif of Margarete Rubik's new collection of essays. The place that Behn occupies in Restoration drama and poetry has been amply credited, and her unmistakable stimulus in the development of the English novel has also been the focus of critical attention in recent years. Now classic essays by Mary Ann O'Donnell in the US, and Bernard Dhuicq, Janet Todd, Derek Hughes, Jane Spencer or Ros Ballaster in Europe, among many others, have prepared the ground for a fertile discipline in literary studies which focuses on this remarkable figure. As Rubik makes clear in Aphra Behn and Her Female Successors, the essays contained in this volume constitute a selection of the papers presented at a conference held in 2010 at the University of Vienna, organised under the auspices of the "Aphra Behn Europe" Society. Accordingly, the editor states the nature of the contributions as follows: "They approach Behn's works from a variety of new perspectives and put this pioneering Restoration author in the context of the writing practices and philosophical theories of her time in general and of her female contemporaries and successors in particular" (Rubik 2011:12). For this purpose, the contributors in this book try to bridge the gaps between Behn and some of her immediate and much later followers.

Rebecka Grontstedt's essay opens the collection by engaging with an aspect of Behn's production that has often been considered 
inconsistent or insubstantial: her literary criticism. In claiming that the prefatory and paratextual materials in Behn's plays need to be reconsidered as critical pieces in their own right and that in them the author delineates her dramatic theory, Grontsdedt's proposal is in tune with a similar line of research proposed by critics of the early novel like Paul Salzman, who sees these materials as the first extant theories on the incipient genre of the novel (1999:302). Grontstedt points to Behn's lack of a formal education in the classics as one probable reason why she did not attempt long critical exertions and chose instead to vent her dramatic theory only in her prefaces and introductions which worked at the same time as commendations to her plays (2011:23). This thesis proves right when Grondstedt explores, for example, the prologues and epilogues to Sir Patient Fancy, The Rover, The Lucky Chance, or The Emperor of the Moon, among others, to illustrate complex issues relating to dramatic theory and staging in the late seventeenth century, like the new tastes of the changing audience from high to low brow, or Behn's disappointment with the patronage system. The author's conclusion extends further to later women writers who also attempt criticism, many of them Behn's successors, suggesting that she was for them a model to follow.

Next, Margarete Rubik's chapter proposes a detailed reading of some of Behn's "strong" female characters. She focuses on the figure of the amazon, which refers both to a "masculine" representation of women and to an androgynous construction ironically charged with sexual allure and misogynist tropes. Rubik thus distinguishes between "classic" amazons and other types of "masculine" women, including female viragos, women in male disguise and roaring girls. It is interesting how she uses Hughes' brilliant interpretation of Restoration theatre as primarily dominated by a "capacity for violence" (2004:34-35) to support the view that Behn endows her amazons with this ability only to prove that their violence is hardly associated to effective power. By attending to particular examples the female characters in The Feigned Courtezans are a case in point Rubik argues that these violent and wilful women rarely enjoy the dramatist's sympathies (2011:49). Her concluding remarks portray Behn's residual use of the Amazon figure: women who might adopt 
masculine roles (and male dress) ironically to perpetuate gender commodification. ${ }^{1}$

The next entry by Oddvar Holmesland turns from drama to poetry and tries to situate Behn's utopian text, The Island of Love, in the larger context of women's writing. The author claims that this poem needs to be read as a critique of patriarchal discourse, but he also makes clear that his purpose is to discuss it in the wider framework of English humanism (2011:59). An interesting feature that the article centres on is the generic complexity of the text that for Holmesland explains many of the reductive critical interpretations of the poem so far. He suggests, therefore, that Lysander's changing nature and behaviour can be understood only by taking into account the varied perspectives of pastoral, romance and realism (2011:70). The essay ends up suggestively by pointing out that Behn's purpose may be to explore a "gentle" kind of masculinity, encompassing heroic virtue and a more egalitarian view of love as friendship.

Antoinette Curtin writes one of the most engaging chapters in the volume. She chooses an interdisciplinary study that draws on plenty of seventeenth-century materials to set Behn's treatment of beauty conventions in a true Restoration context. Using Fontenelle's "A Discovery of New Worlds," for example, she frames the construction of the feminine within the scientific paradigm of the time and establishes relationships between cultural readings of beauty and specific generic types like the romance (2011:77). Curtin also manages to extend the discussion about the limits of beauty to the work of some of Behn's followers, like Delarivier Manley in The Adventures of Rivella (1714). She invariably associates beauty with power and analyses its dynamics in Behn's drama, poetry and fiction, like The Feign'd Curtizans, "The Golden Age," or Love-Letters between a Nobleman and His Sister and The Fair Jilt. Once more, the conclusion spins around the notion of generic experimentation in Behn's works: as she breaks free from the strict boundaries of genre she rejects either/or categorizations of the beautiful woman.

This is followed by Jorge Figueroa-Dorrego's essay which analyses the figure of the jilt in Behn's fiction. He starts with a

\footnotetext{
${ }^{1}$ Hughes' comments on Cleomena's complex behaviour as an Amazon in The Young King, a play that Rubik also approaches in her article, are remarkable. He explains how she turns from warrior and prospective murderer to docile maid in female attire, finally surrendering power (2001:24-25).
} 
thorough etymological description of the term to proceed to the analysis of this recurrent type in Restoration literature, and especially in prose fiction. Figueroa-Dorrego thus conceives the jilt understood as villainess, criminal or sometimes whore - in the context of other famous Restoration stories which gravitate partly on the historical, like Mary Carleton's (2011:98-99). Interestingly, the author studies this liminal figure in the light of the Spanish picaresque. Reading Salvaggio (1993:263), Figueroa-Dorrego maintains that the transgressive nature of the jilt allows Behn's characters - and Miranda in The Fair Jilt in particular - to embrace masculine behaviour from a genre and gender viewpoint: "Miranda adopts the typical masculine role in romance and amatory fiction, taking the initiative in courtship, seducting, ravishing, ruining the lover's reputation, and coming out on top" (2011:103).

Violetta Trofimova's article offers a comparative study of Behn's third part of Love-Letters (1687) and Jane Barker's The Lining of the Patch-Work Screen (1726), focusing on the role of the paranormal in both the public and the private spheres. In so doing, Trofimova draws admirably on the context of seventeenth-century specialized books on the topic, coetaneous literary productions and, above all, the rationalist approach adopted by the Royal Society. In the end, the essay proposes that the choice and treatment of magic responds to a real debate going on at the time and that, especially in Behn's work that Trofimova particularly engages with - , can be easily interpreted in relation to politics as forces that could destabilise public order but might be also strategic and beneficial in the domestic world.

Roy Eriksen's is the last chapter in the collection devoted to Behn's work and the members of the Nineties generation. It includes, nonetheless, more contemporary referents like Doris Lessing's 1950s novel The Grass is Singing, and specializes on the productive topic of experimentation in Behn's prose fiction, focusing on the way she plays with the boundaries between generic conventions. Eriksen argues that Behn's ambivalent use of genre is in tune with her ideological ambiguity in the novella, going from her Royalist and conservative beliefs to a more progressive treatment of slippery topics like slavery and colonialism. Eriksen's statement about the intergeneric liaisons in Behn's Oroonoko is analysed in relation to former mannierist novellas like George Gascoigne's The Adventures of Master F.J. (1573) and to mediaeval hagiography. 
Colonialism is the main theme in Barbara Britton Wenner's work, as she compares Behn's Oronooko and Anna Maria Falconbridge's visions of West Africa, separated by a span of more than one century. In so doing, she proposes an analysis at different levels, taking into account questions of gender -two women's perspectives of the West African landscape-, genre -literary conventions in travel writing-, and politics -the anti-slavery discourse that develops in England throughout the eighteenth century. Especially relevant is Britton Wenner's treatment of the notion of space and landscape that she connects with liminality as a primarily female experience, and that runs counter to the representation of character (2011:140-141). The author observes how both writers differ, though, in one aspect: Falconbridge chooses reality when Behn still draws on romance. Both works managed, nonetheless, to forward their respective political agendas: Behn's support of the Stuart kings and Falconbridge's bitter complaint about the treatment given by the Sierra Leone Company.

Claudia Heuer moves even closer in time to assess twentiethcentury criticism on Behn's poetry. Her chapter assesses Virginia Woolf's ambiguous attitude towards Behn's figure, especially in relation to notions of female conduct and literary creativity. Heuer is concerned with diverse topics in Behn such as (literary) androgyny, in tune with Woolf's Orlando, or the dubious notion of female authorship (especially in the case of Elizabethan women). The article focuses, though, on Woolf's work while Behn remains a reference in passing.

Aspasia Velissariou's text is a brilliant contribution to the volume. The author chooses Anim-Addo's play Imoinda as a counterpoint to Behn's representation of the same character in her Oroonoko. The author's choice of two texts that seem to engage in full conversation is remarkable. What is most interesting is how Velissariou's moves swiftly from feminist appropriations of Behn's novella - both postructuralist and postcolonial - to vindicate Behn's mouldering of Imoinda. She carries out a detailed comparative analysis of both texts to define Behn's stance as radically sceptic and astonishingly modern: "She questions the humanist appreciation of simple biological existence as the highest value by showing that at some point heroic death might be preferable to disposable life" (2011:177). Velissariou looks for critical support in Hughes (2002:17) 
to suggest that Behn chooses the hard way in developing her politics of femininity, leaving essentialism behind.

Wolfgang Görtschacher's essay closes Rubik's collection and moves in a different direction. In contrast to previous chapters, Aphra Behn's works are not the focal point. Görtschacher chooses instead a mystery novel published in 1995 by Molly Brown, Invitation to a Funeral, dramatizing Behn's life and her relationships with other relevant figures of the Restoration, like John Wilmot or Nell Gwyn. The author engages with a formal analysis of Brown's fiction, drawing on the dramatic nature of the novel, the real and fictional personas behind the characters, and genre conventions. Görtschacher's wish in the end is to rescue from oblivion an influential political and literary period like the Restoration, and the fascinating figure of Aphra Behn in particular.

In conclusion, this text is no doubt a valuable addition to the rich bibliography on Aphra Behn's studies, which might appeal both to specialists on Behn's oeuvre and also to scholars in English literature. In general terms, it amounts to an innovative discussion on the malleability of the concept of literary genre in Behn's work, and an original treatment of gender issues that are necessarily entrenched in the social, political and literary context of the time.

\section{References}

Hughes, Derek 2001. The Theatre of Aphra Behn. Basingstoke: Palgrave.

2002. "Race, Gender, and Scholarly Practice: Aphra Behn's Oroonoko." Essays in Criticism 52: 1-22.

Hughes, Derek and Janet Todd eds. 2004. The Cambridge Companion to Aphra Behn. Cambridge: Cambridge University Press.

Salvaggio, Ruth 1993. "Aphra Behn's Love: Fiction, Letters, and Desire." Ed. Heidi Hutner. Rereading Aphra Behn. History, Theory, and Criticism. Charlottesville: University Press of Virginia: 253-270.

Salzman, Paul 1999. "Theories of Prose Fiction in England: 1558-1700." Ed. Glyn P. Norton. The Cambridge History of Literary Criticism. Vol. III. The Renaissance. Cambridge: Cambridge University Press: 295-304.

How to cite this review:

Villegas López, Sonia. Review of Margarete Rubik ed. 2011. Aphra Behn and Her

Female Successors (Wien: Lit Verlag). SEDERI 23 (2013): 173-178.

Author's contact: sonia.villegas@dfing.uhu.es 